\title{
HYDROLOGICAL INVESTIGATIONS OF
}

SOIL AND VEGETATION TYPES

IN THE

LOWER COTTER CATCHMENT

D.A.Gilmour w

1965 s. 
HYDROLOGICAL INVESTIGATIONS OF SOIL AND VEGETATION TYPES

IN THE LOWER COTTER CATCHMENT

\author{
by \\ Donald Allan Gilmour
}

A thesis submitted to the Australian National

University for the degree of Master of Science

Department of Botany

1965 
FRONTISPIECE - General view of the lower Cotter catchment looking west over the dam. 
$\cos ^{2} x^{2}-2=$
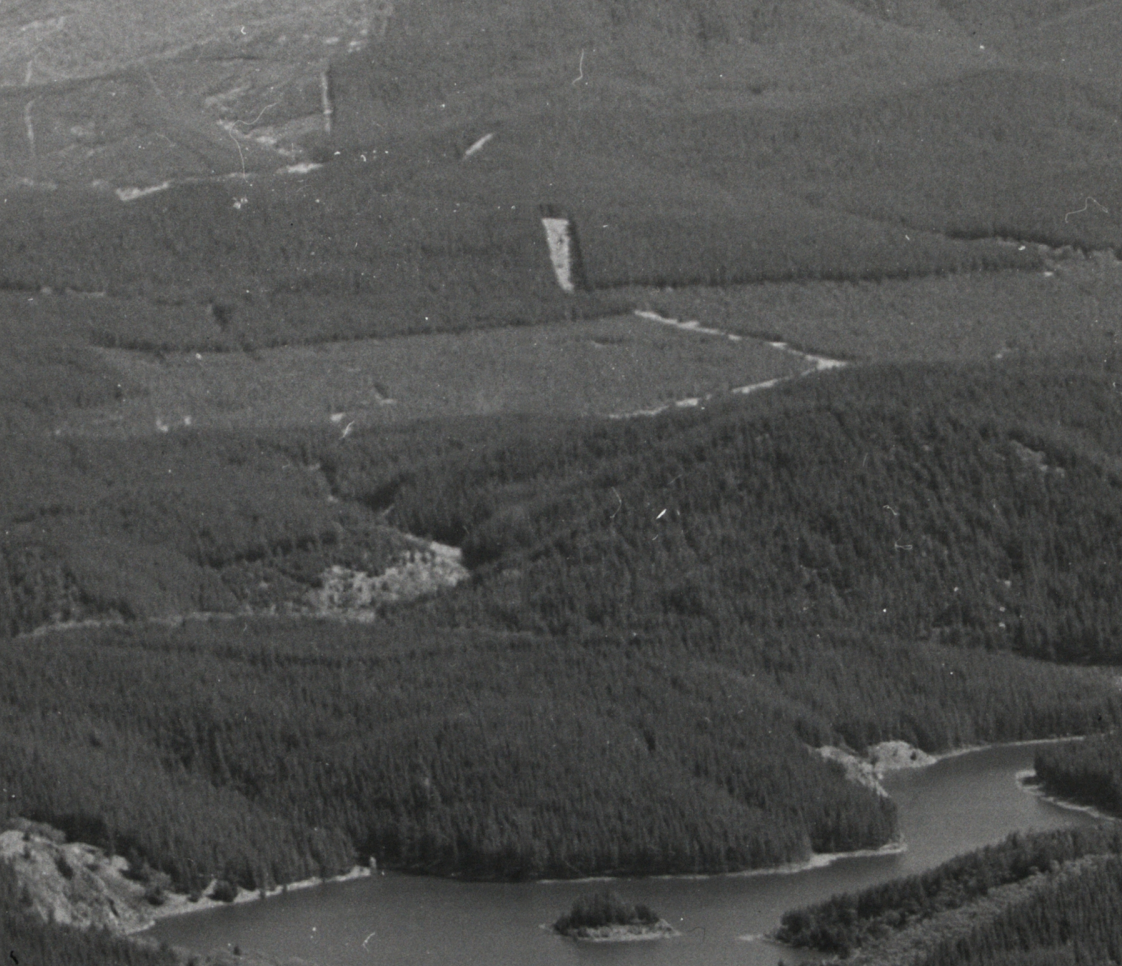

tatingsis

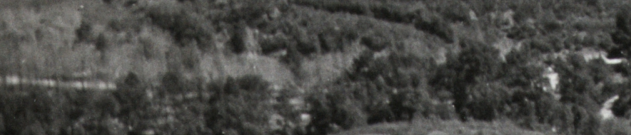

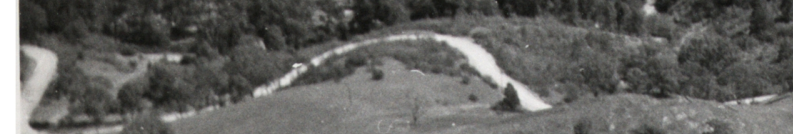

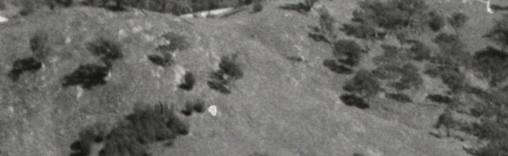

.

. 


\section{CONTENTS}

Page

PREFACE

SUMMARY

CHAPTER 1. INTRODUCTION TO PROJECT 3

1. General introduction and aims of project 3

2. Description of study area 4

(a) Physiagraphy 4

(b) Vegetation 4

(c) Geology 5

(d) Soils $\quad 5$

(e) Sites for detailed study 5

3. Weather pattern during study period 8

4. Experimental procedure 9

(a) Permanent plots 11

(b) Infiltration measurements 12

(c) Prescribed burning experiment 18

(d) Revegetation of a firebreak 19

(e) Soil measurements 21

(i) Physical 21

(ii) Chemical 23

$\begin{array}{ll}\text { CHAPTER 2. RESULTS } & 24\end{array}$

1. Results of natural rainfall studies 24

(a) Relation of surface run-off to amount and type of ground cover 24

(b) Relation of surface run-off to soil physical characteristics

(c) Relation of soil loss to amount and type of ground cover and to surface dryness 
(d) Relation of nutrient loss to amount of ground cover

(e) Influence of rainfall intensity on surface run-off and soil loss; and importance of infrequent heavy rains

2. Results of infiltration studies

(a) Relation of infiltration to amount and type of ground cover

(b) Relation of infiltration to soil physical characteristics

3. Hydrological effects of management practices

(a) Effect of prescribed burning in a pine plantation on infiltration and nutrient loss

(b) Effect of revegetating a firebreak on infiltration and soil loss

4. Condition of undisturbed eucalypt forest and pine plantations derived from it

Site A

Site B

42

Site C

Site D

CHAPTER 3. DISCUSSION

CONCLUSIONS

60

ACKNOWLEDGEMENTS

61

REFERENCES 


\section{APPENDICES}

Appendix

Detailed descriptions of study sites I

Weather pattern during study period II

Plot data in relation to natural rainfall studies III

Soil physical characteristics IV

Nutrient losses during study year V

Plot data in relation to infiltration studies VI

Prescribed burning experiment ' VII

Comparison of pines and eucalypts at Sites $A, B, C$ and $D$ 


\section{PREFACE}

"Water, or the lack of it, sets limits to man's activities" (Colman. 1953). This statement holds great significance for Australia, which contains some of the world ${ }^{\circ} \mathrm{s}$ most arid regions. Water is a renewable resource, and in the form of precipitation is fairly independent of man's activities. However, from the time water reaches the earth's surface until it returns to the atmosphere through evaporation, it may be controlled to a large extent by human influence.

$$
\text { of all the characteristics of a watershed, vegetation }
$$
is the only one that can be altered relatively easily, so a thorough knowledge of the hydrological processes which are influenced by vegetation is essential for sound watershed manag ement . 
The quality of Canberra's domestic water has deteriorated in recent years, and various conditions within the catchment area have been blamed. This project was designed to investigate the stability of the land surfaces in the lower Cotter catchment. and to determine ground cover requirements necessary to keep soil and water losses to a minimum.

Surface run-off and soil loss were measured for each natural rainfall for a year on 41 permanent plots covering a range of soil-vegetation types in the lower Cotter catchment.

A portable rainfall simulator was constructed for use in measuring infiltration rates, and the artificial rainfall (at an intensity of 320 points per hour) had drop size and velocity characteristics similar to those of natural rain of the same intensity.

Infiltration measurements were made on the 41 permanent plots and on 33 additional roving plots during the summer of 1963-1964.

Each plot was characterised for type and amount of ground cover, and the soil physical properties of bulk density, capillary and non-capillary porosity, and particle size distribution.

On soil types with low non-capillary porosity in the subsoil (restricted drainage) the non-capillary porosity of the surface soil was found to be the most important factor in controlling infiltration and surface run-off. Non-capillary porosity of the surface soil was related to weight of ground cover, and reductions in the ground cover below $4,000 \mathrm{~g}$ per 60 square feet resulted in a marked increase in surface run-off.

On soil types with high non-capillary porosity in the subsoil (even drainage) surface run-off was at a low level at all times, and the amount of ground cover present had little or no effect.

Soil loss on soil types with restricted drainage in the subsoil was dependent on the amount of ground cover present. Ground cover in excess of $4,000 \mathrm{~g}$ per 60 square feet resulted in 
negligible soil loss; but reductions in ground cover below this value resulted in a large increase in soil loss.

For a given amount of ground cover (below $4,000 \mathrm{~g}$ per 60 square feet) soil loss increased exponentially with rainfall intensity. Most of the soil loss which occurred during the year resulted from a small number of high intensity rains.

Chemical analyses of the soil loss indicated high fertility erosion.

Soil loss was negligible on soil types with even drainage throughout the profile irrespective of the amount of ground cover.

Infiltration rates were slightly higher under eucalypts than under pines and a hydrophobic effect was present under both types when the ground cover was dry.

Low intensity prescribed burning in a pine plantation did not result in any significant reduction in infiltration rates, However, the concentration of nutrients in the run-off water from two subsequent intense artificial rainfalls was significantly increased by the burning.

Native eucalypt forests and well established pine plantations provided excellent catchment protection on all soil types. Young pine plantations on soil types with restricted drainage in the subsoil provided insufficient protection. Most of the soil loss measured during the year originated on very bare areas such as firebreaks.

Improvement in catchment protection could be attained by vegetating bare areas such as roads and firebreaks. 
CHAPTER 1

INTRODUCTION TO PROJECT

\section{General introduction and aims of project}

The Cotter River flows through an uninhabited forested catchment on the western border of the Australian Capital Territory, and is the sole source of Canberra's domestic water supply.

Since 1926 about 10,000 acres of the native eucalypt forest in the lower portion of the catchment have been converted to coniferous plantations. During this period, and especially in recent years, poor quality water has been a source of annoyance to the people of Canberra. The causes of this apparent deterioration in water quality have been a matter for debate. Some of the factors which have been blamed for the deterioration are: poor quality eucalypt forests, pine plantations, roads, firebreaks, power lines, dam construction and unstable river banks. 
The objects of the present study are:

(1) To isolate and evaluate vegetation and soil influences on infiltration, surface run-off and soil movement.

(2) To determine ground cover requirements to assist in the management of the vegetation for domestic water supply.

\section{Description of study area}

\section{(a) Physiography}

The Cotter catchment has an area of 186 square miles above the lower dam, and a river mileage of 47 miles. It varies in elevation from 1,675 feet at the dam to 6,274 feet at Mount Bimberi in the south-western corner. The topography is gentle to hilly in the lower reaches and very steep in the middle and upper reaches. The river flows from south to north and the width of the valley is very uniform, varying from about five to seven miles. Figure 1 shows the position of the valley in relation to the surrounding features, and the frontispiece shows a general view of the lower catchment.

(b) Vegetation

Four main vegetation types are found in the Cotter catchment (after Pryor 1955):

(i) Alpine Woodland, which is found on the western and southern ranges of the catchment above 5,200 feet. It is only relatively small in area.

(ii) Savannah Woodland, which generally occurs below about 


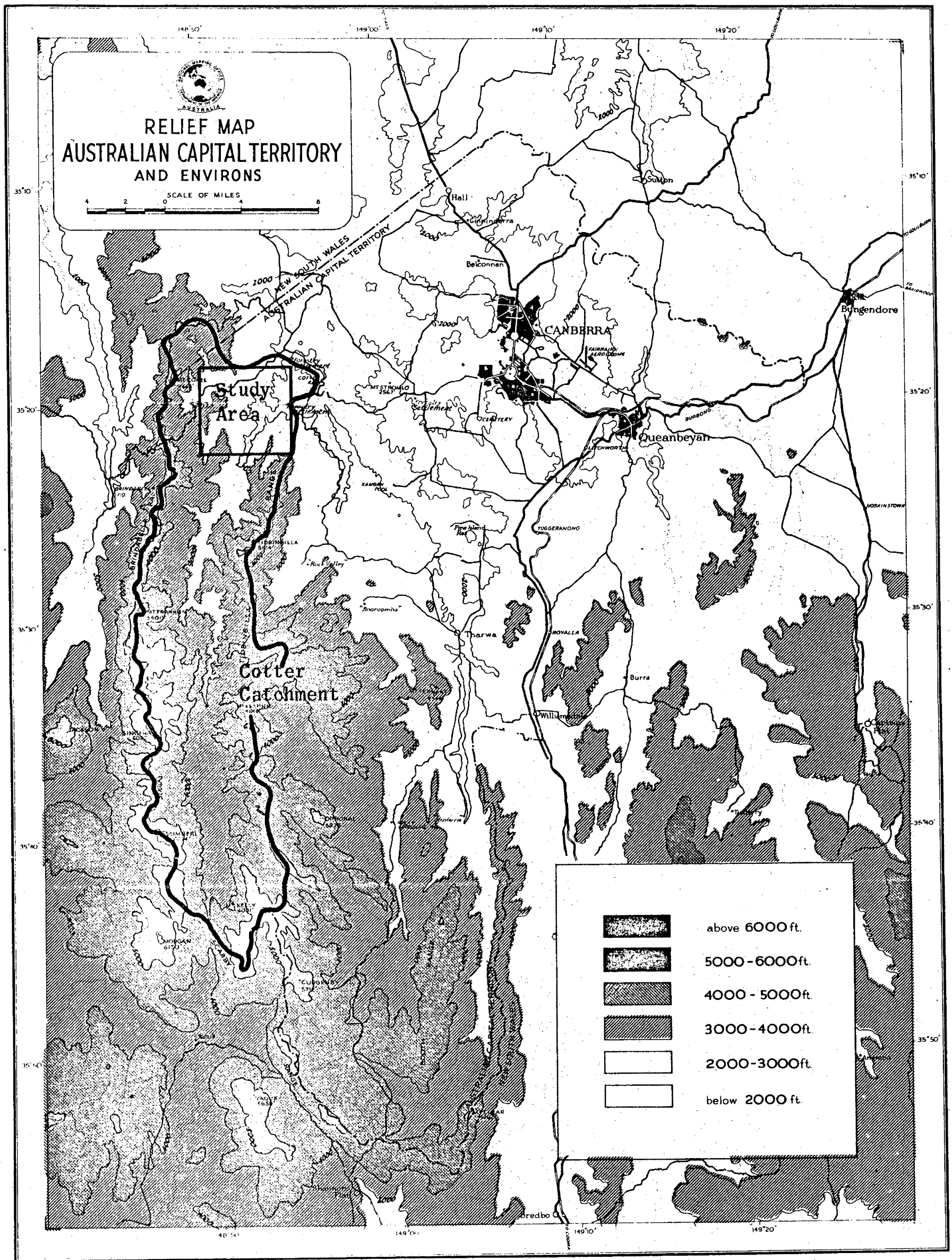

FIGURE 1 Map showing location of Cotter catchment and study area. 
2.500 feet. Most of it was cleared for grazing in the early part of the century, and has since been converted to pine plantations.

(iii) Dry Sclerophyll Forest, which occurs in the lower part of the valley, from about 2,300 to 2,900 feet. A large part of the area covered by this type has also been converted to pine plantations.

(iv) Wet Sclerophyll Forest, which occurs on the steeper, better watered parts of the catchment from about 2,700 feet to the lower limit of the alpine woodland.

(c) Geology

There are three main geological formations in the valley:

(i) Granite and graniorite (igneous).

(ij) Sandstone - slate - chert - greywacke (sediments and metamorphosed sediments).

(iii) Acid tuff - dacite - phyllite - calcareous shale (volcanics and metamorphosed sediments).

(d) $\underline{\text { Soils }}$

Soils vary from red-yellow podzolics at the lower altitudes through deep red forest soils in favourable positions on the middle slopes, to alpine humus sails on the ranges of the western boundary. In areas of strong relief skeletal soils are common.

(e) Sites for detailed study

Four sites (sites A-D) were chosen for the detailed study of run-off and erosion from natural rainfall; and three 


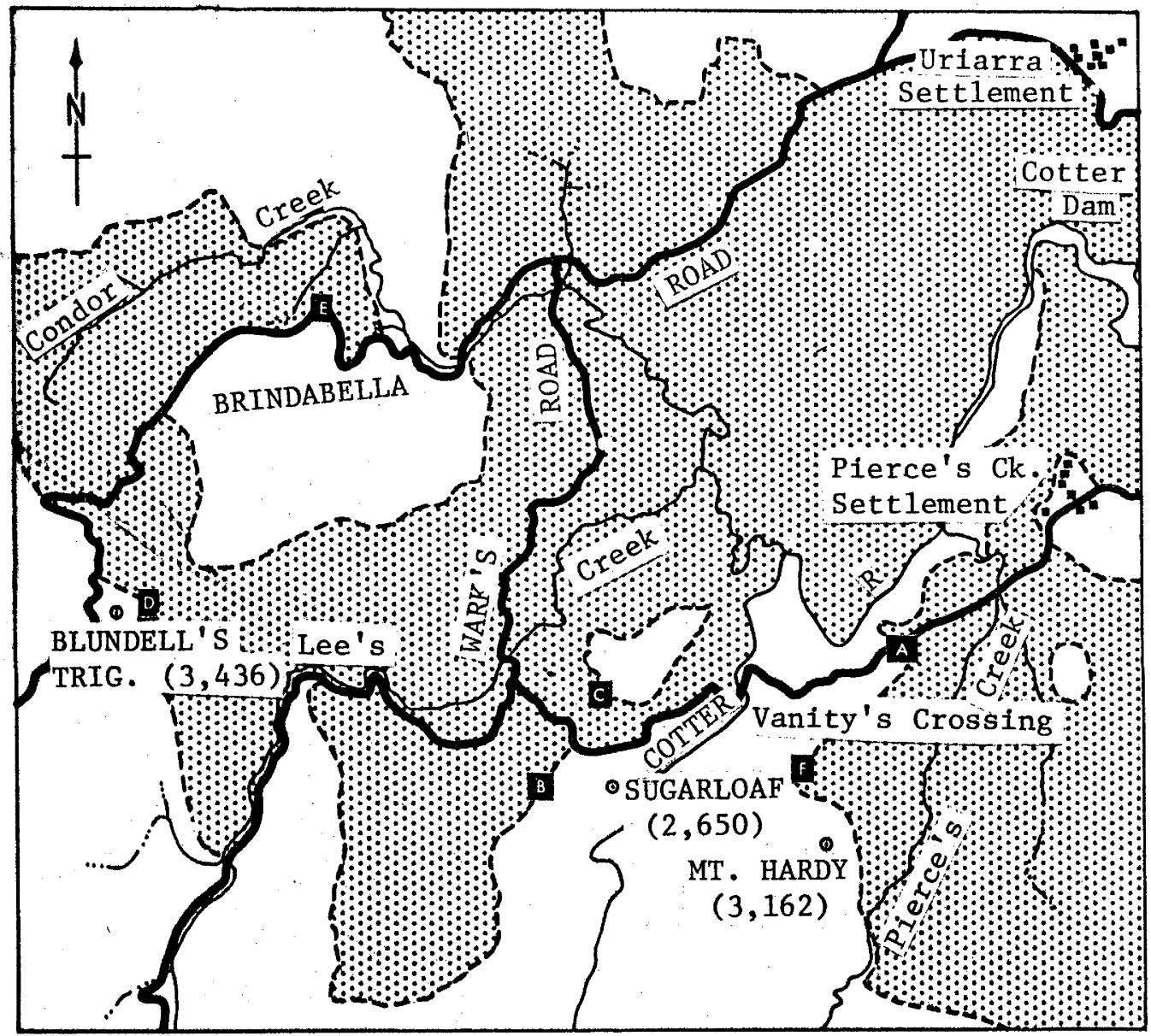

FIGURE 2. LOCATION OF STUDY SITES.

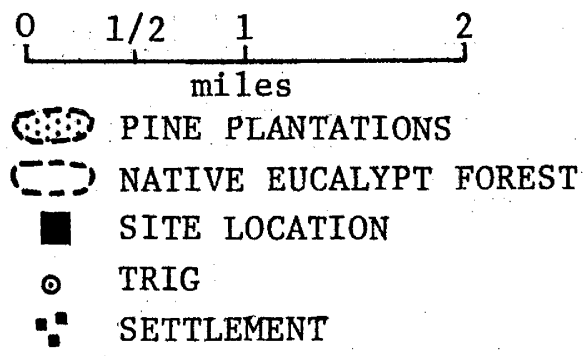


$-6 b-$

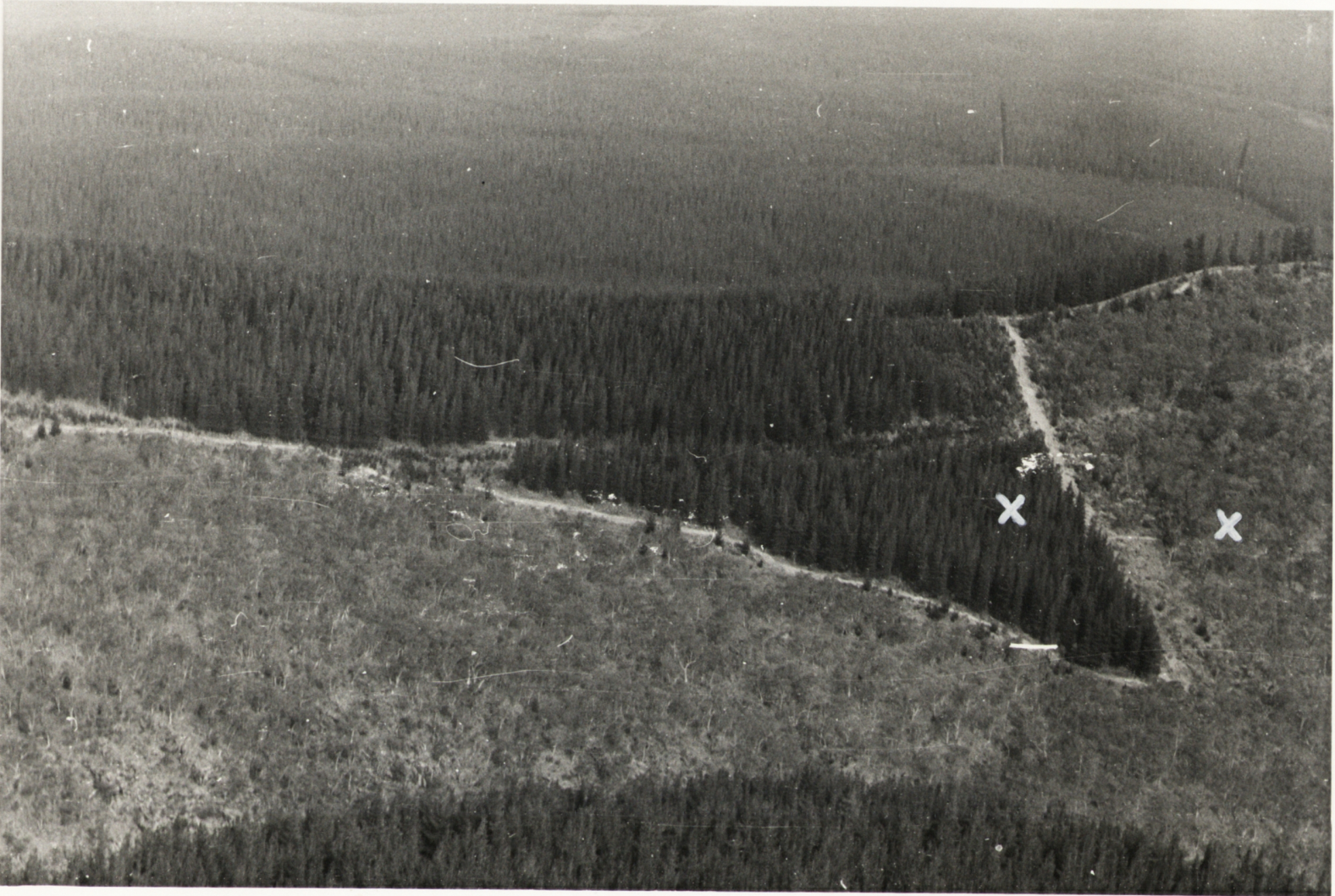

PLATE 1. Site A - dry sclerophyll eucalypt forest and 30 year old pine plantation. 


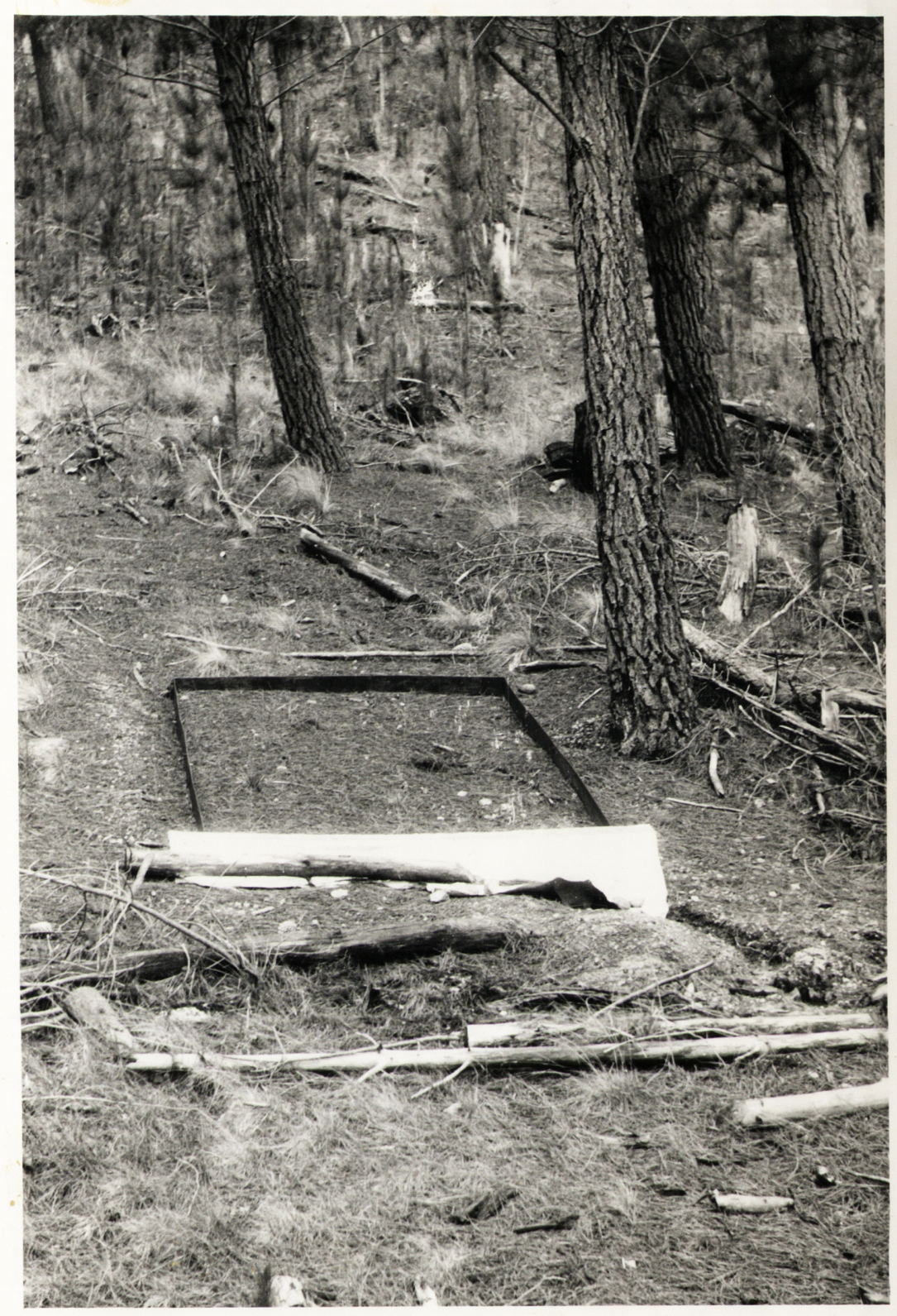

PLATE 2. Site A (pines) showing well developed ground cover of pine litter. 


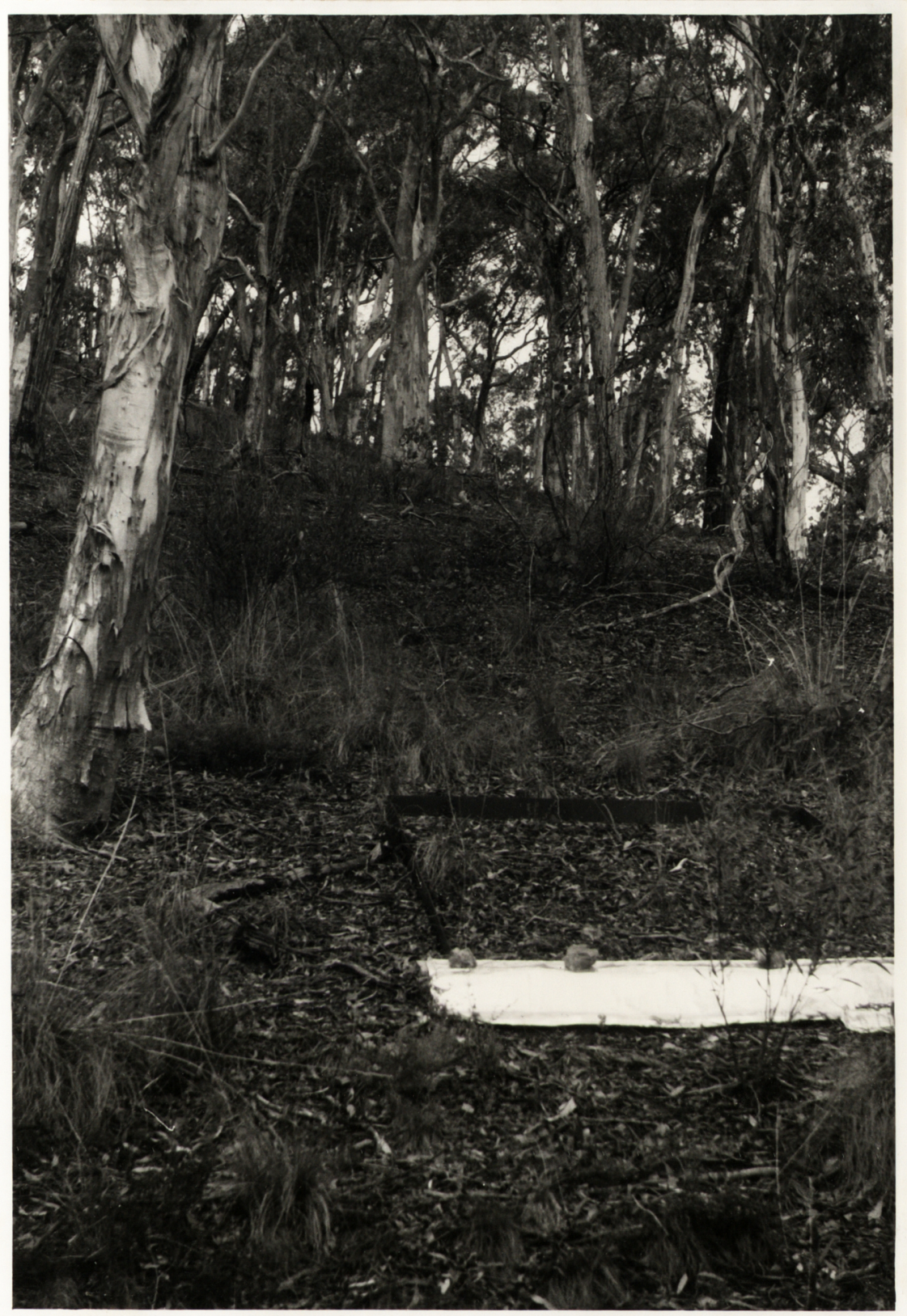

PLATE 3. Site A (eucalypts) showing moderate ground cover of sclerophyll litter. 


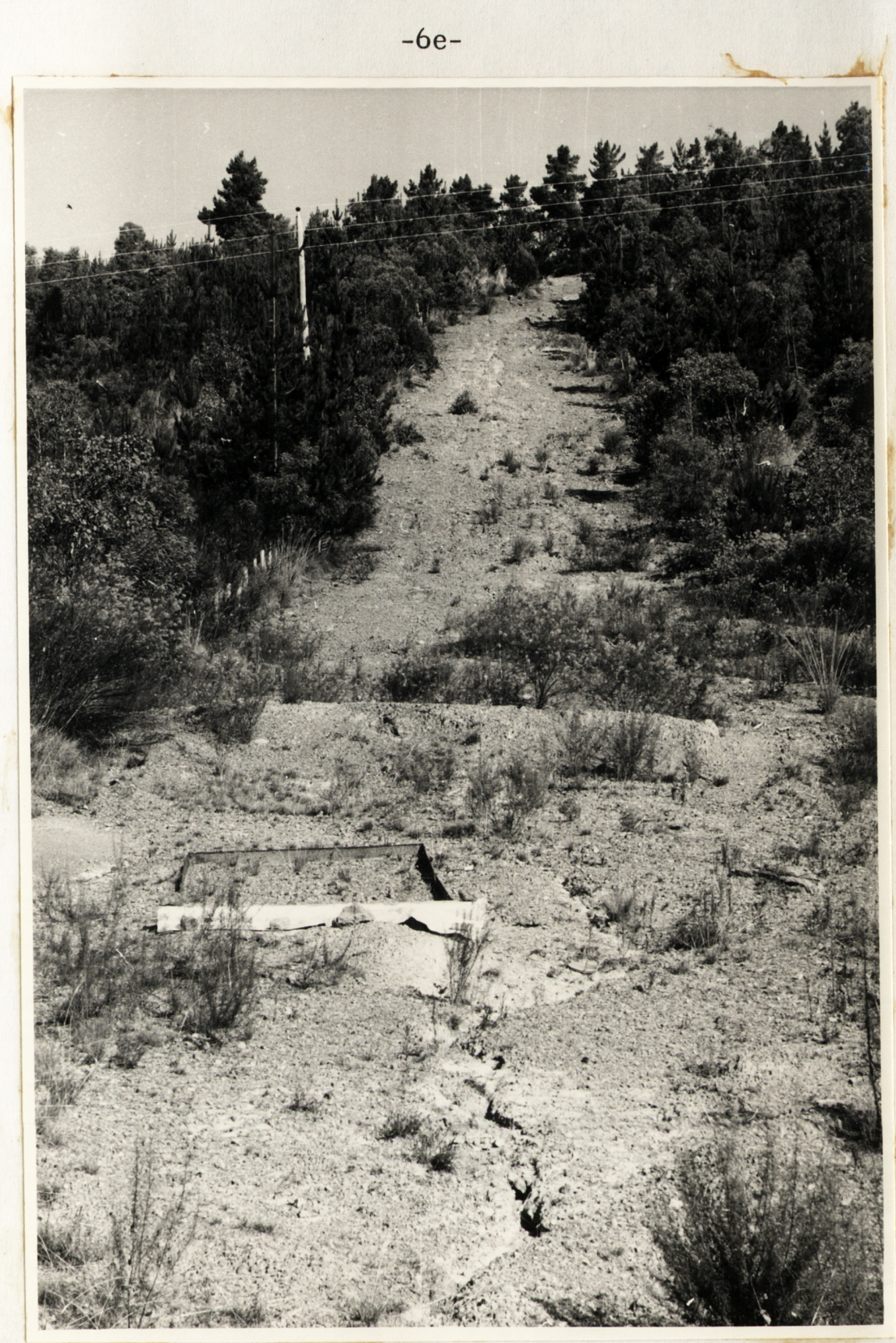

PLATE 4. Site A showing bare firebreak between pines and eucalypts. 


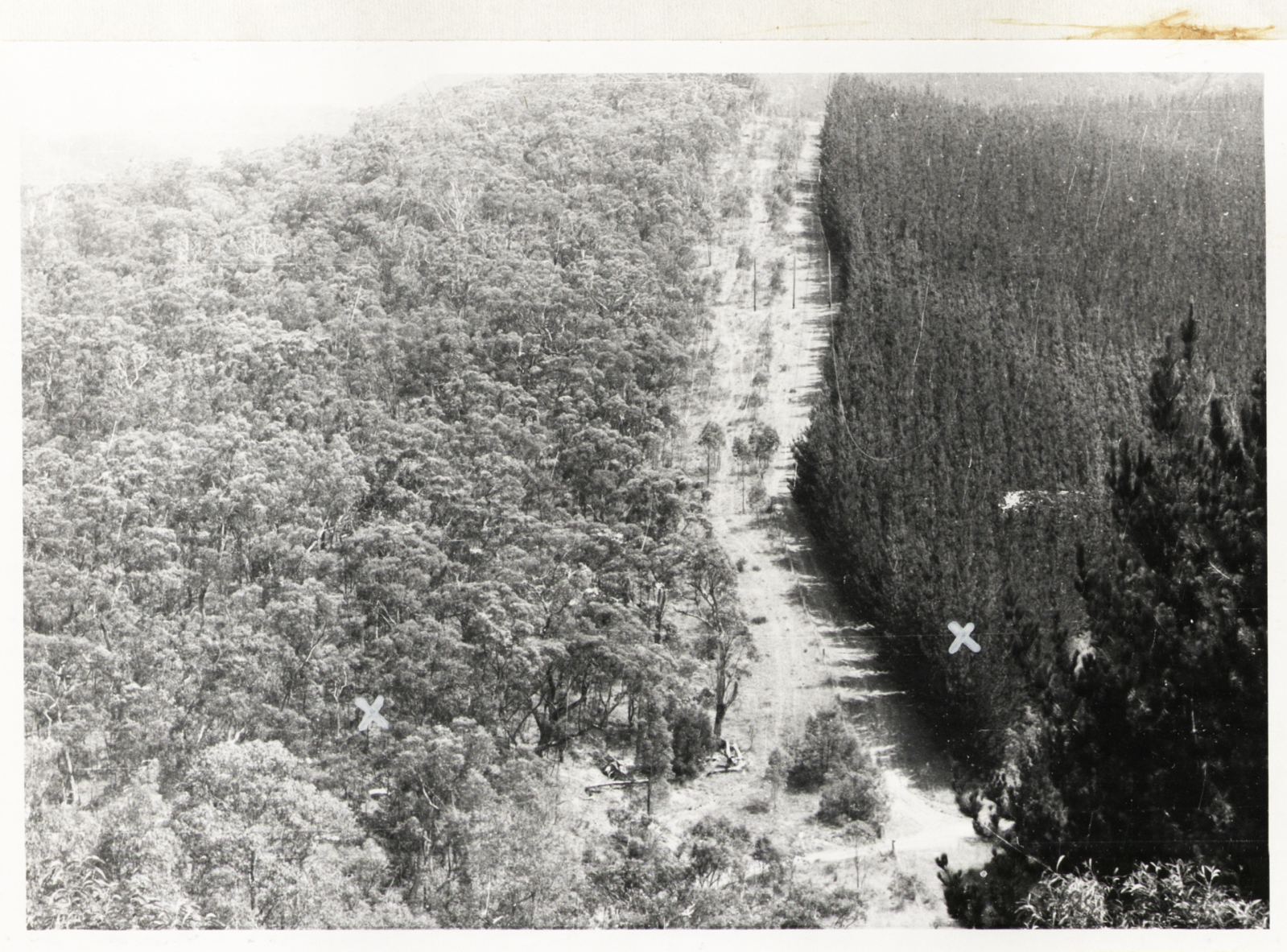

PLATE 5. Site B - dry sclerophyll eucalypt forest and 11 year old pine plantation. 


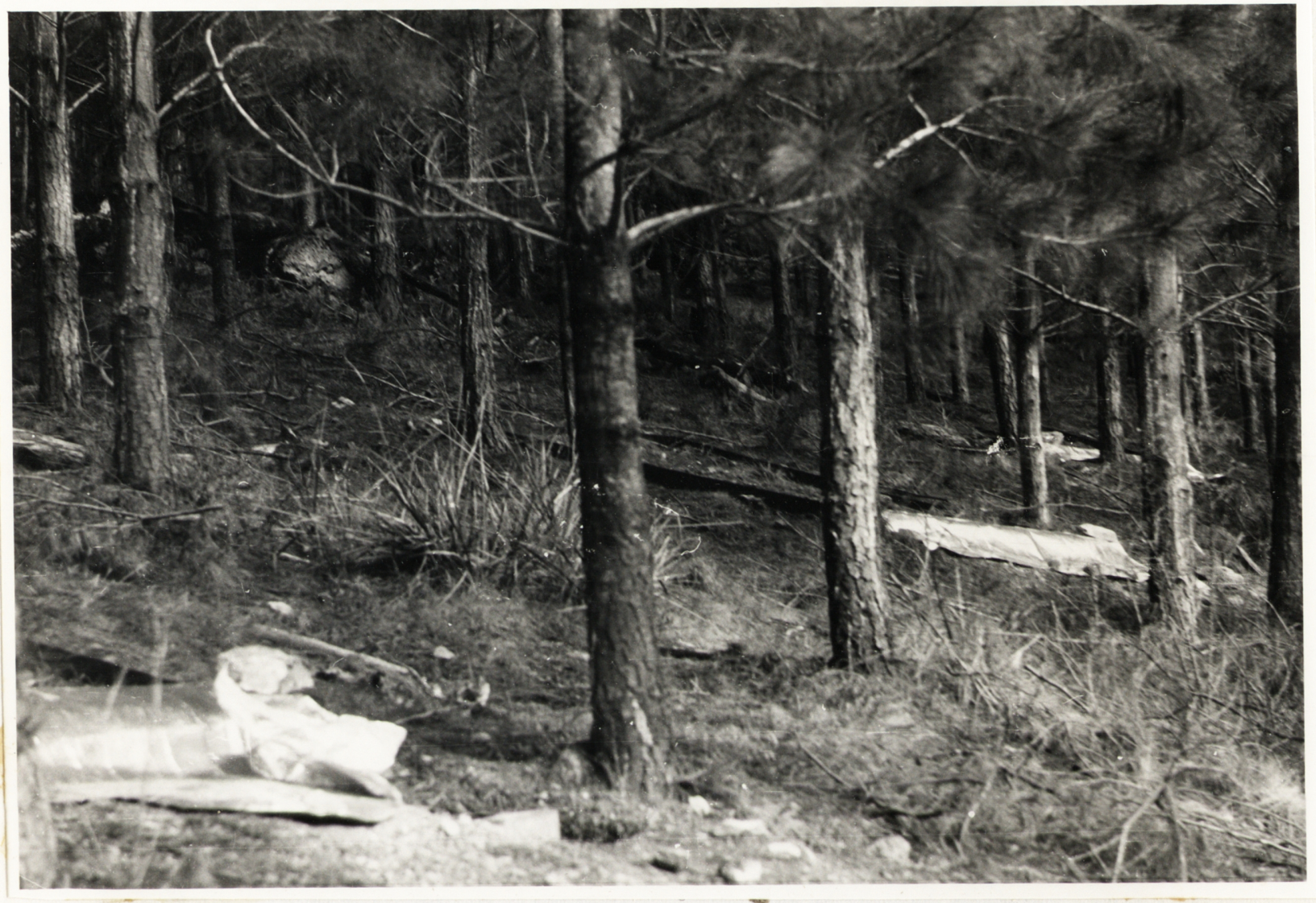

PLATE 6. Site B (pines) showing well developed ground cover of pine litter. 


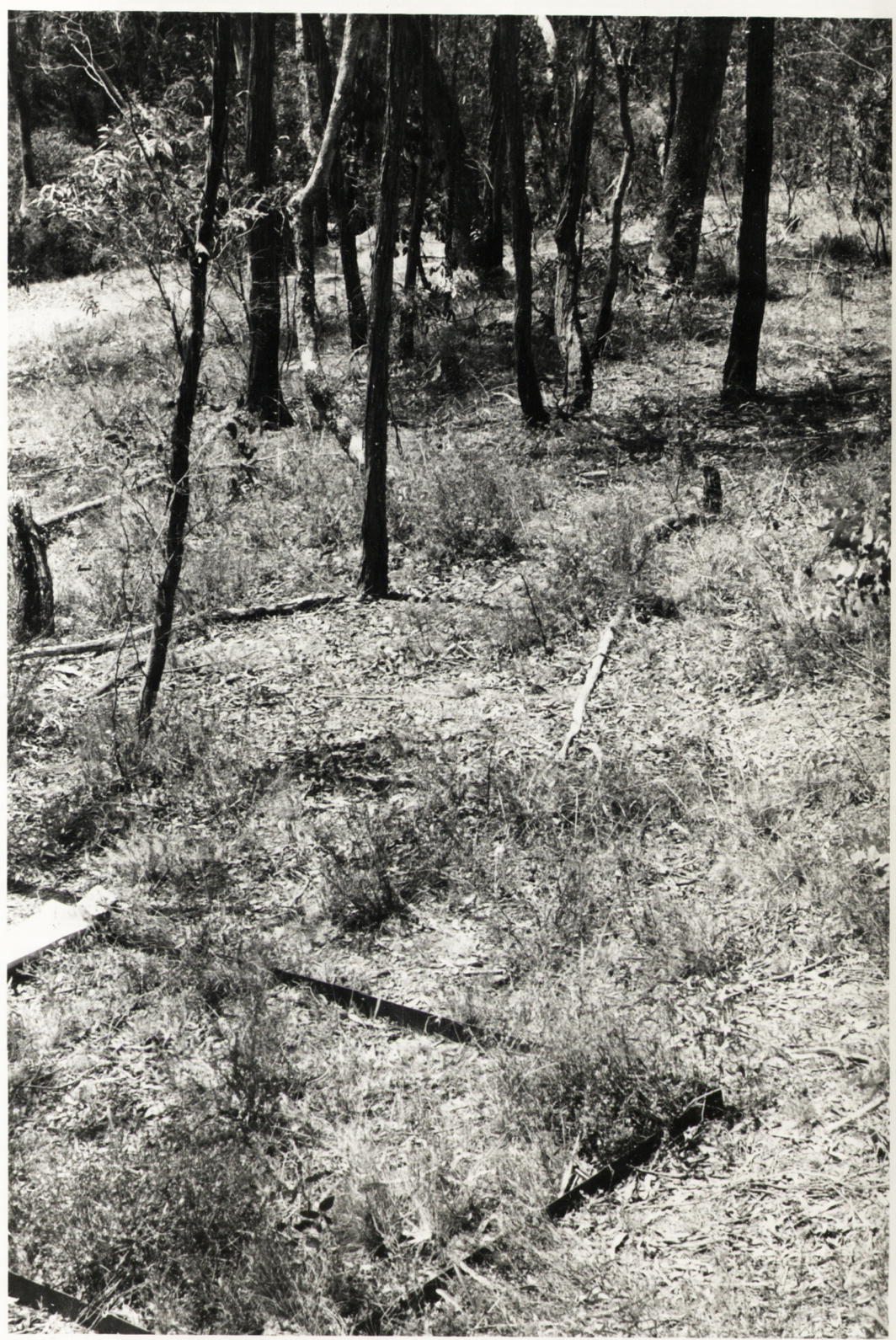

PLATE 7. Site B (eucalypts) showing well developed ground cover of sclerophyll litter and low shrubs. 


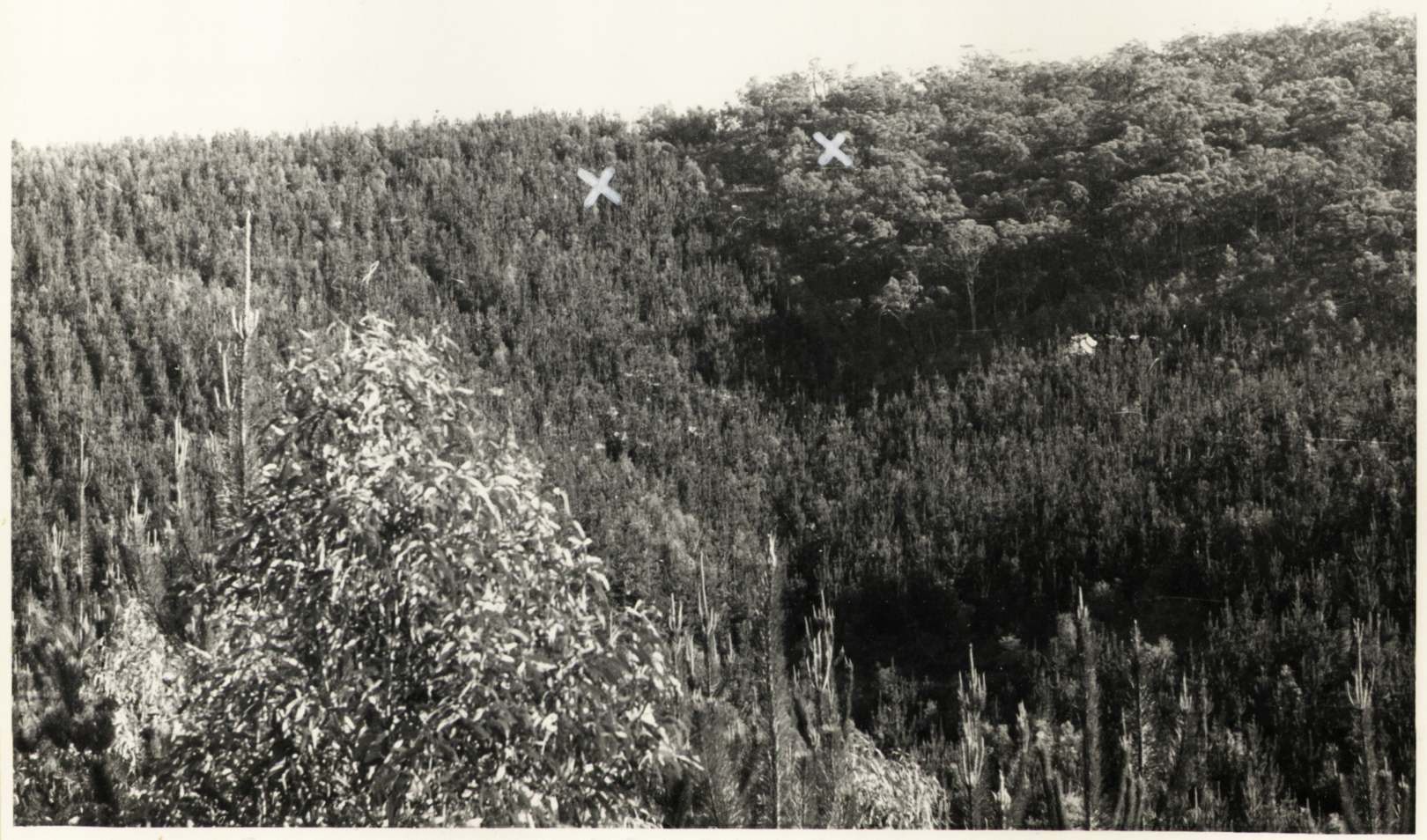

PLATE 8. Site C - dry sclerophyll eucalypt forest and seven year old pine plantation. 


$$
-6 j-
$$

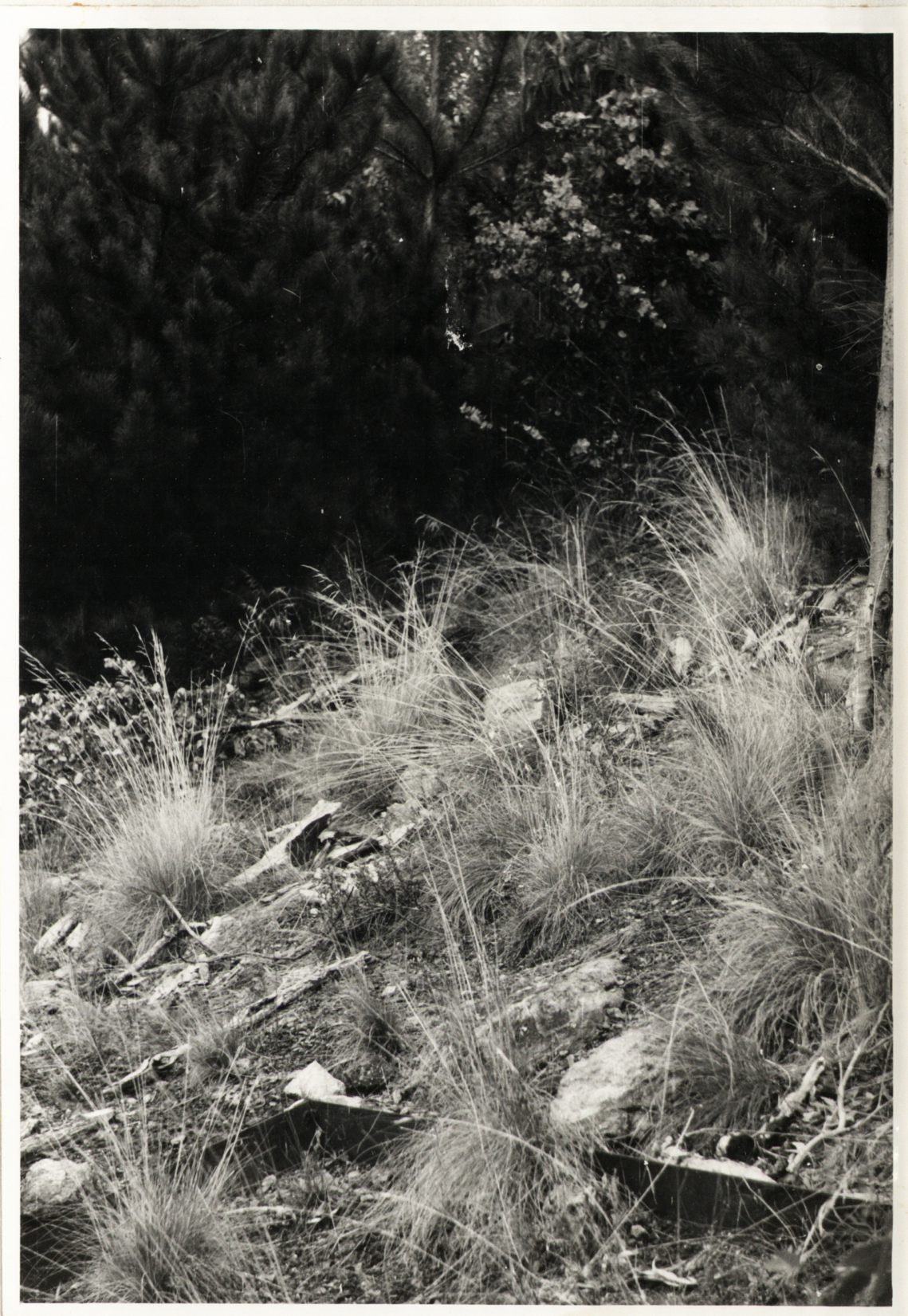

PLATE 9. Site C (pines) showing moderate ground cover of snow grass. 


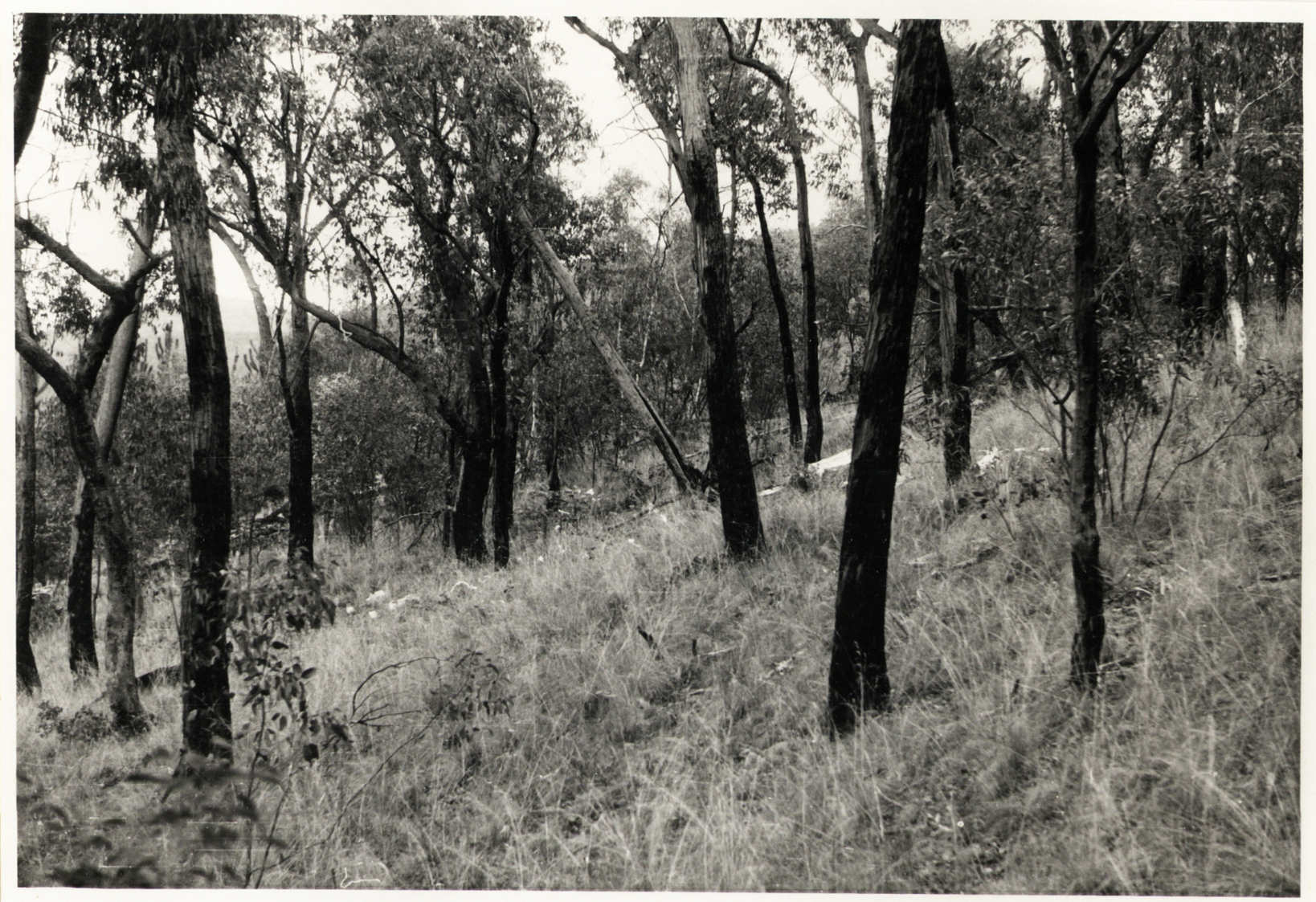

PLATE 10. Site C (eucalypts) showing well developed ground cover of snow grass and sclerophyll litter. 


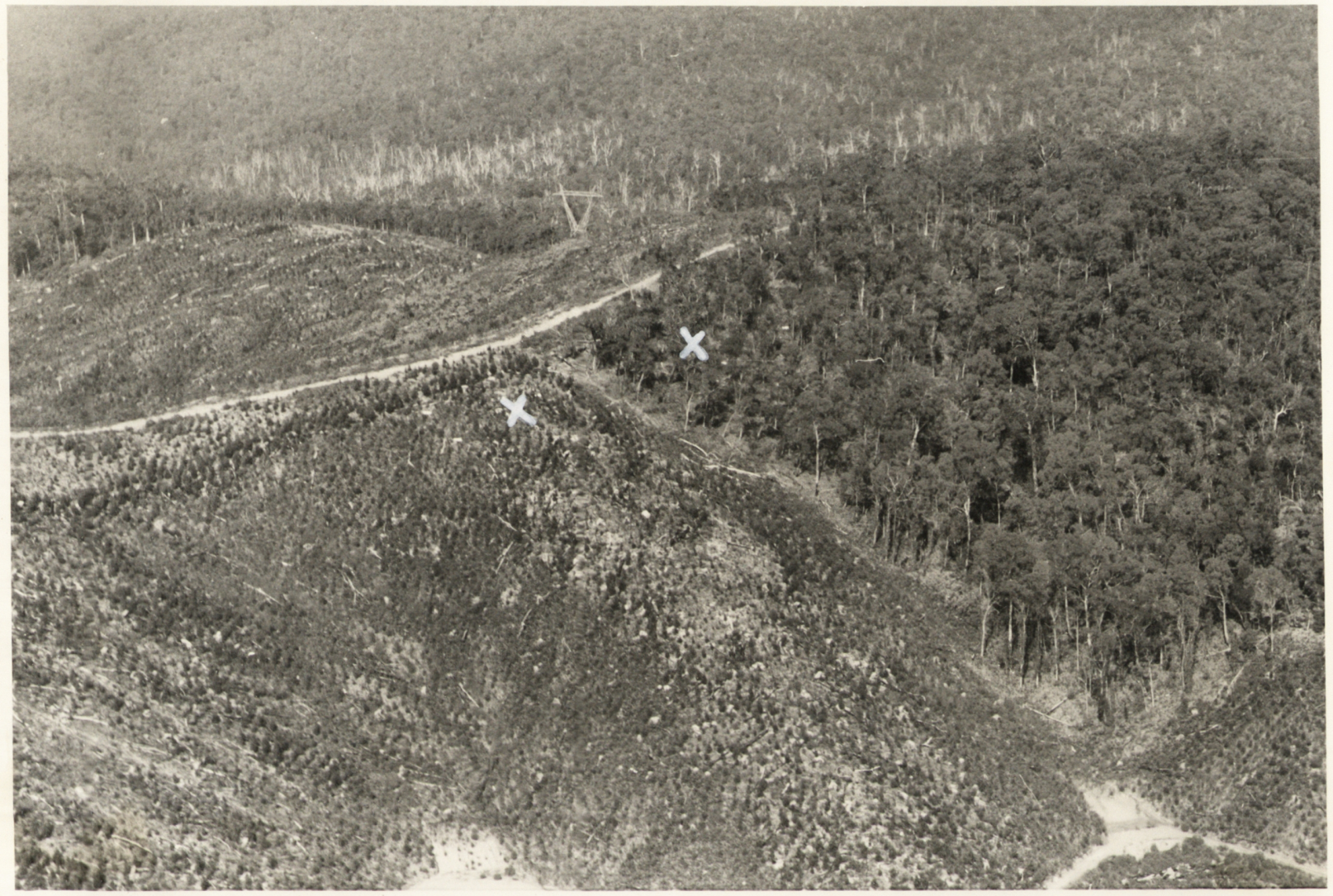

PLATE 11.' Site D - dry sclerophyll eucalypt forest and four year old pine plantation. 


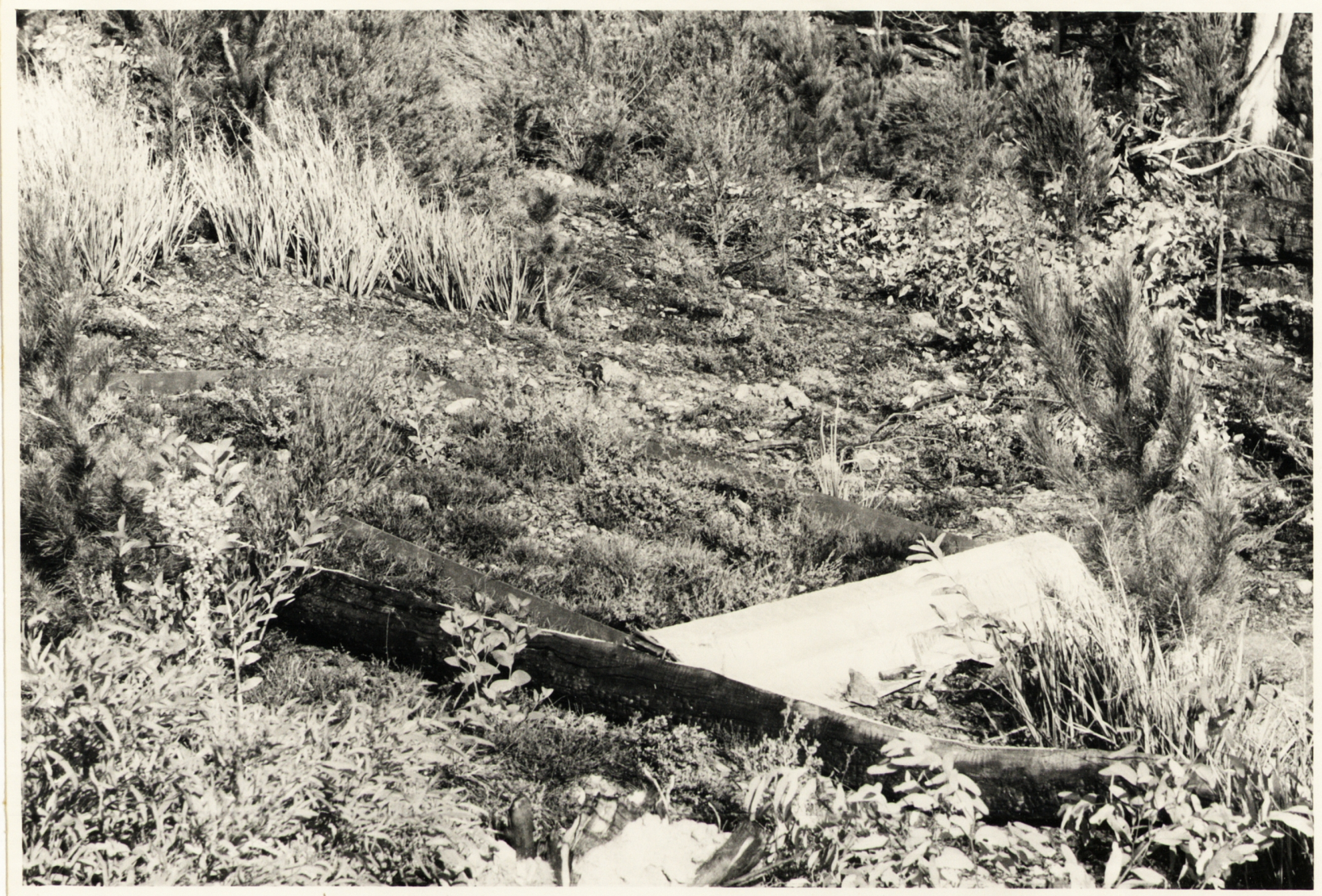

PLATE 12. Site D (pines) showing sparse ground cover of low shrubs. 


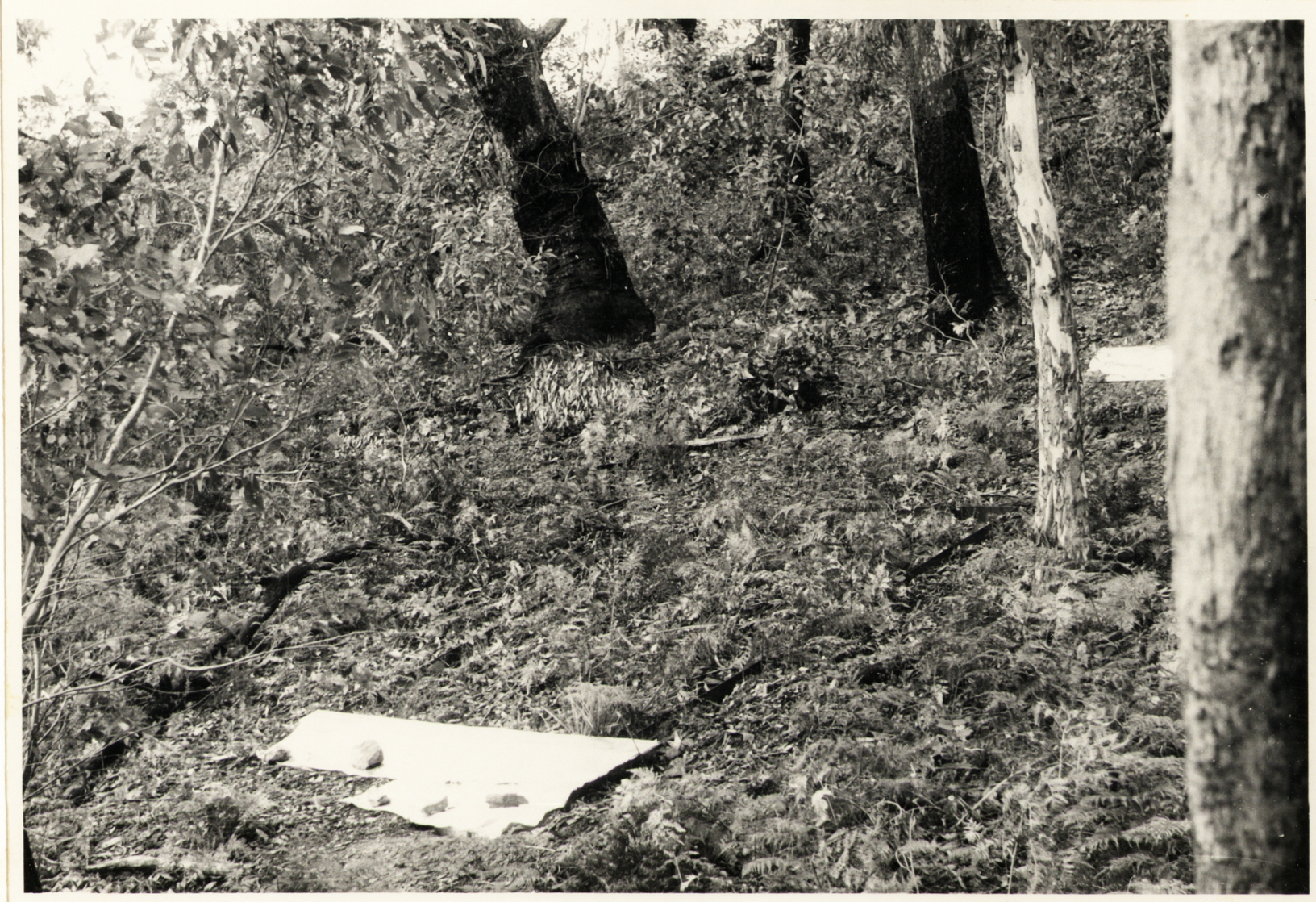

PLATE 13. 'Site D (eucalypts) showing well developed ground cover of sclerophyll litter and bracken fern. 
with leaf litter.

Site C $(2,600$ feet) was located on a skeletal minimal yellow podzolic soil derived from acid tuff, and slopes were about $25^{\circ}$. The dominant eucalypts were $\underline{E}$. dives and $\underline{E}$. macrorhyncha and the forest floor was very well covered with leaf litter and snow grass (Poa caespitosa ${ }^{*}$ ). The pines were planted in 1957 and the floor was moderately covered with snow grass.

Site D $(3,300 \mathrm{feet})$ was located on a skeletal minimal red podzolic soil derived from fine grained sandstones and mudstones, and slopes were about $21^{\circ}$. The dominant eucalypt was E. dives and the forest floor was well covered with leaf litter and bracken fern (Pteridium esculentum). The pines were planted in 1960 and the floor was poorly covered with low growing shrubs. Site E (2,450 feet) was located on a skeletal minimal yellow podzolic soil derived from fine grained sandstones and mudstones, with slopes of about $12^{\circ}$. The dominant eucalypt was E. dives, with E. maculosa as a subordinate species, and the forest floor was well covered with sclerophyll litter. The adjacent pine plantation was planted in 1955 and the floor was well covered with leaf litter and clumps of Poa caespitosa. The firebreak between the two communities was moderately covered with Poa caespitosa.

Site F $(2,600$ feet) was located on a firebreak between a 1934 pine plantation and a low quality eucalypt forest. The Gray (1963). 
soil was a skeletal minimal yellow podzolic derived from fine grained metamorphosed sediments. The firebreak was almost bare of vegetation, but the forest floors on either side were well covered with leaf litter. Slopes were about $18^{\circ}$.

Site G (1,850 feet) was located in a pine plantation at Stromlo Forest on slopes of about $5^{0}$. The soil type was a yellow podzolic derived from acid tuff. The plantation was established in 1941 and the floor was well covered with slash piles and leaf litter.

\section{Weather pattern during study period}

The period of study occupied a full year: from October 1963 to September 1964 inclusive. Generally speaking. spring and summer were dry, while autumn and winter were very wet. Details of the monthly rainfall for each site are given in Appendix II. The rainfall at sites $A$ and $D$ is shown graphically in Figure 3. Most of the rainfall of the springsummer period occurred as the result of thunderstorm activity and the disparity between the two sites is variable and related only to individual storm patterns. However, the higher altitude site $D(3,300$ feet) received substantially more rain than site A $(2,100$ feet) during the autumn-winter period when most of the rain originated from wide spread low pressure systems and associated cold fronts.

Figure 4 shows the frequency of high intensity rainfall for site $A$, the intensity distribution of the other sites being of the same pattern (see Appendix II). Although the spring-summer period was very dry, it experienced many more 


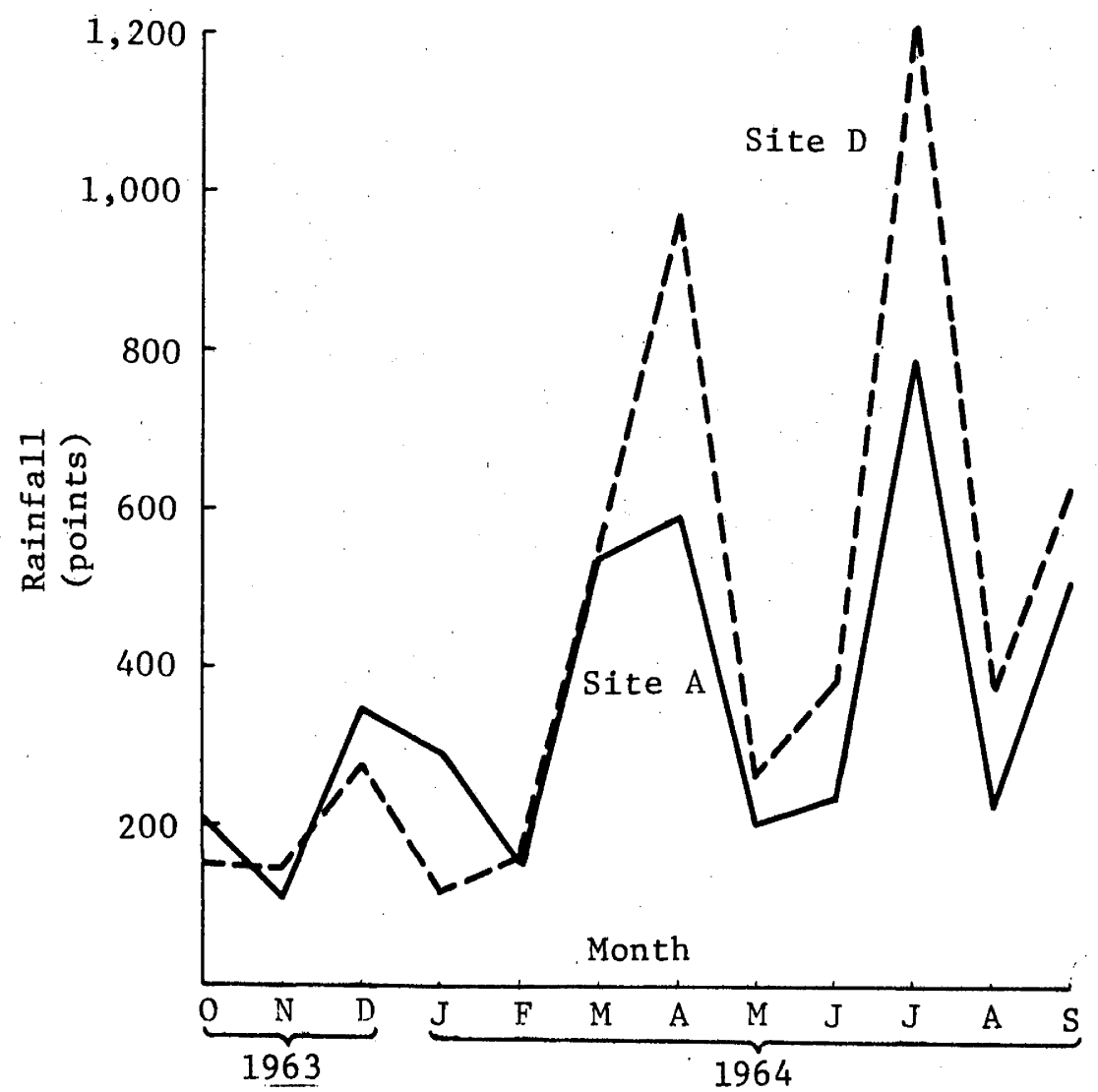

Figure 3. Monthly rainfall for Sites $A$ and $D$.

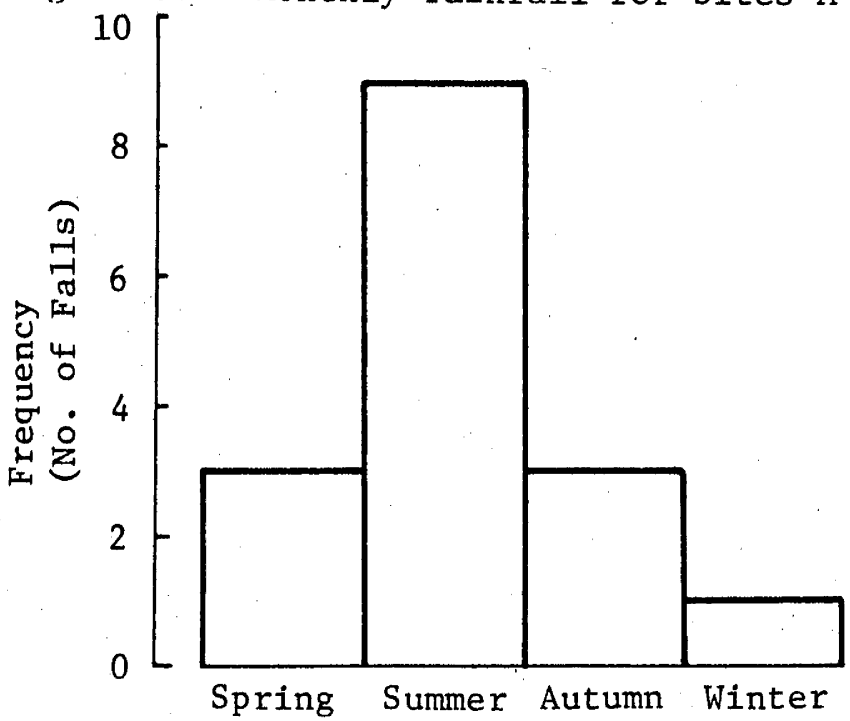

Figure 4. Seasonal frequency of rainfalls exceeding $40 \mathrm{pts} / \mathrm{hr}$ (max. 10 minute intensity) - site A. 
high intensity falls than occurred during the remainder of the year. An examination of the records from Fairbairn Meteorological Station for an eight year period (1955-1963) revealed a similar seasonal distribution of intense rainfall (Figure 5) .

Snow fell at all sites during July and August, but only persisted on the ground at site $D$, where approximately 230 points of precipitation occurred as snow. However, it never persisted for more than three days after a fall.

Very drying conditions were encountered during the summer months due to the combination of high temperatures, low humidities and long periods between rainfalls. Figure 6 shows the temperature and humidity pattern during the year and Appendix II gives details of monthly temperature and humidity and the number of days between rains.

The weather pattern during the year was a satisfactory one for study purposes, as a full range of precipitation and drying conditions was experienced.

4. Experimental procedure

There are three basic approaches to the problem of carrying out catchment experiments:

(i) Laboratory

(ii) Small plots

(iii) Watersheds

Laboratory and small plot techniques give results comparatively quickly and cheaply. They both suffer from the limitation 


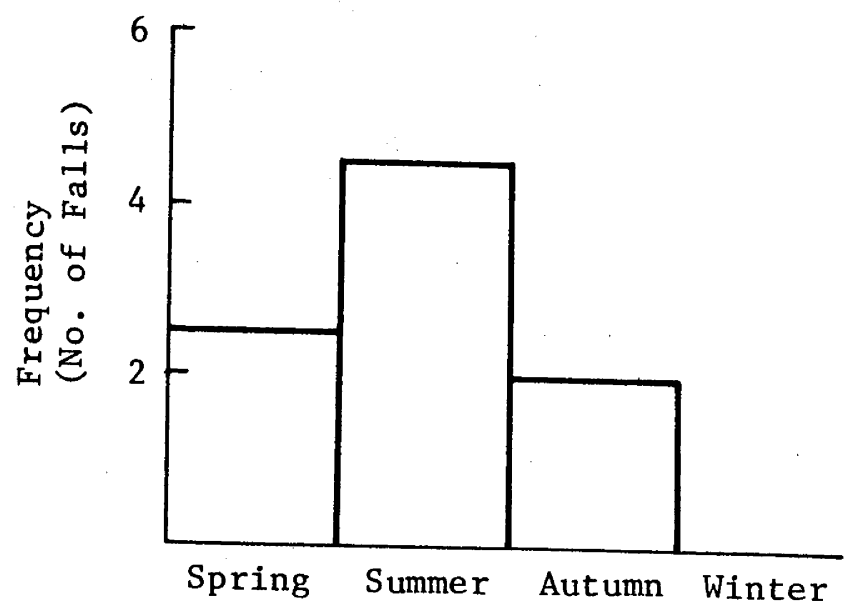

Figure 5. Seasonal frequency of rainfall exceeding $80 \mathrm{pts} / \mathrm{hr}$ (max. 15 minute intensity) - average of 8 years' data from Fairbairn Meteorological Station

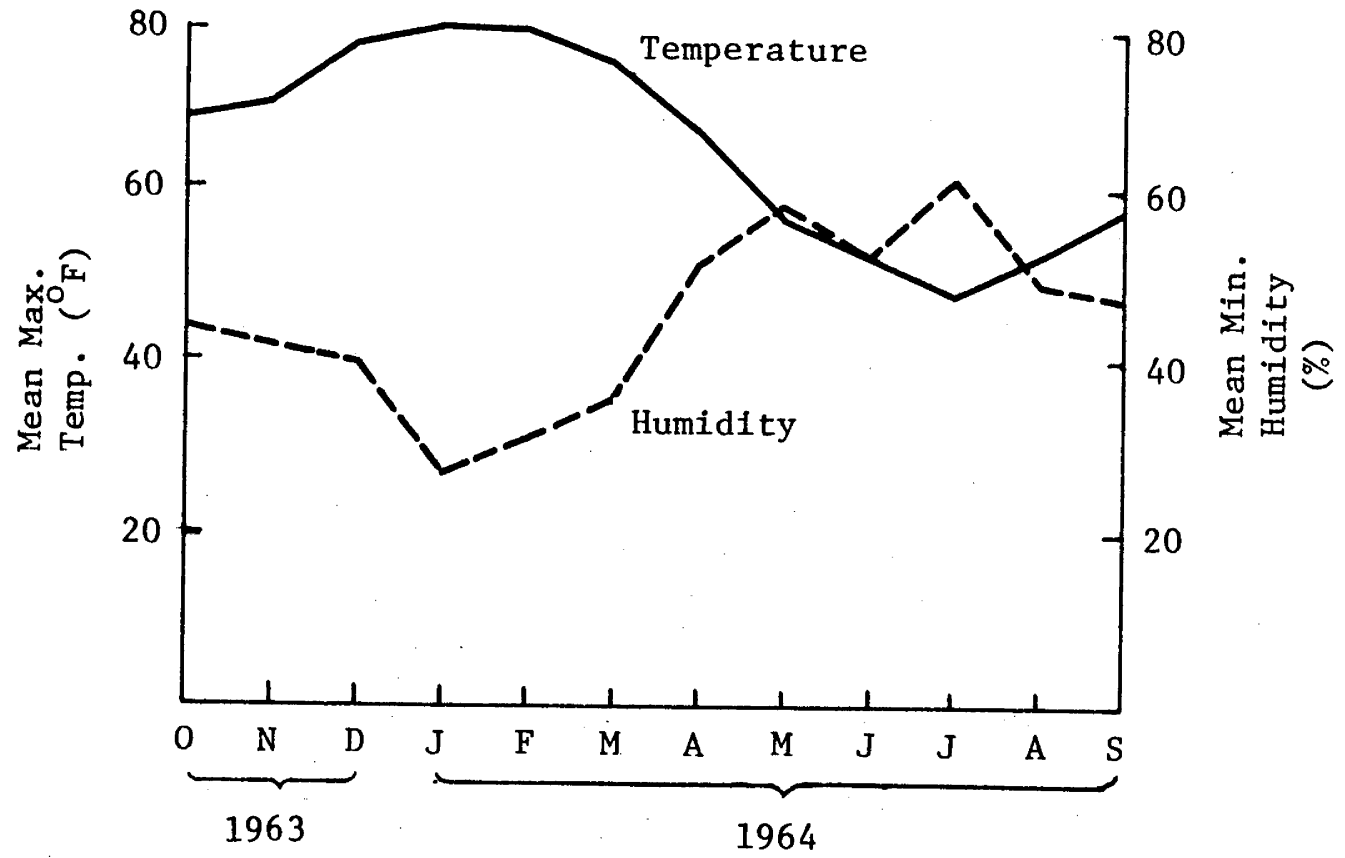

Figure 6 .

Mean maximum temperature and mean minimum humidity for each month during the study period (measured at Uriarra Forest Station). 
that the results are difficult to apply quantitatively on a watershed basis. However, they provide the only satisfactory methods of studying the individual hydrologic processes. The use of watersheds is essentially a long term project and instrumentation is expensive. Gross measurements of precipitation, streamflow and sediment yields over the whole catchment give an overall indication of the effect of a treatment, but the reasons for a particular result are not always clear. Ideally, all three approaches should be integrated to obtain the maximum amount of information.

It was decided that the small plot approach would give the greatest amount of information in the time available. This approach enabled a wide range of conditions to be sampled with sufficient replication to allow the use of statistical methods in analysing the results.

Steel plot frames were designed to enclose an area of 60 square feet - construction details may be seen in Plate 14. The ten foot side was hinged in the middle to accommodate a change in slope. The collecting trough was located at the foot of the plot and driven into an exposed face of soil. The exposed face was covered with concrete to prevent any subsurface flow from entering the collecting trough; and the concrete was moulded to the level of the soil surface. A plastic covering ("B.F.C. Liquid Envelope") was applied to the concrete in case shrinkage developed at the steel-concrete interface. Installation details may be seen in Plate 15 . 


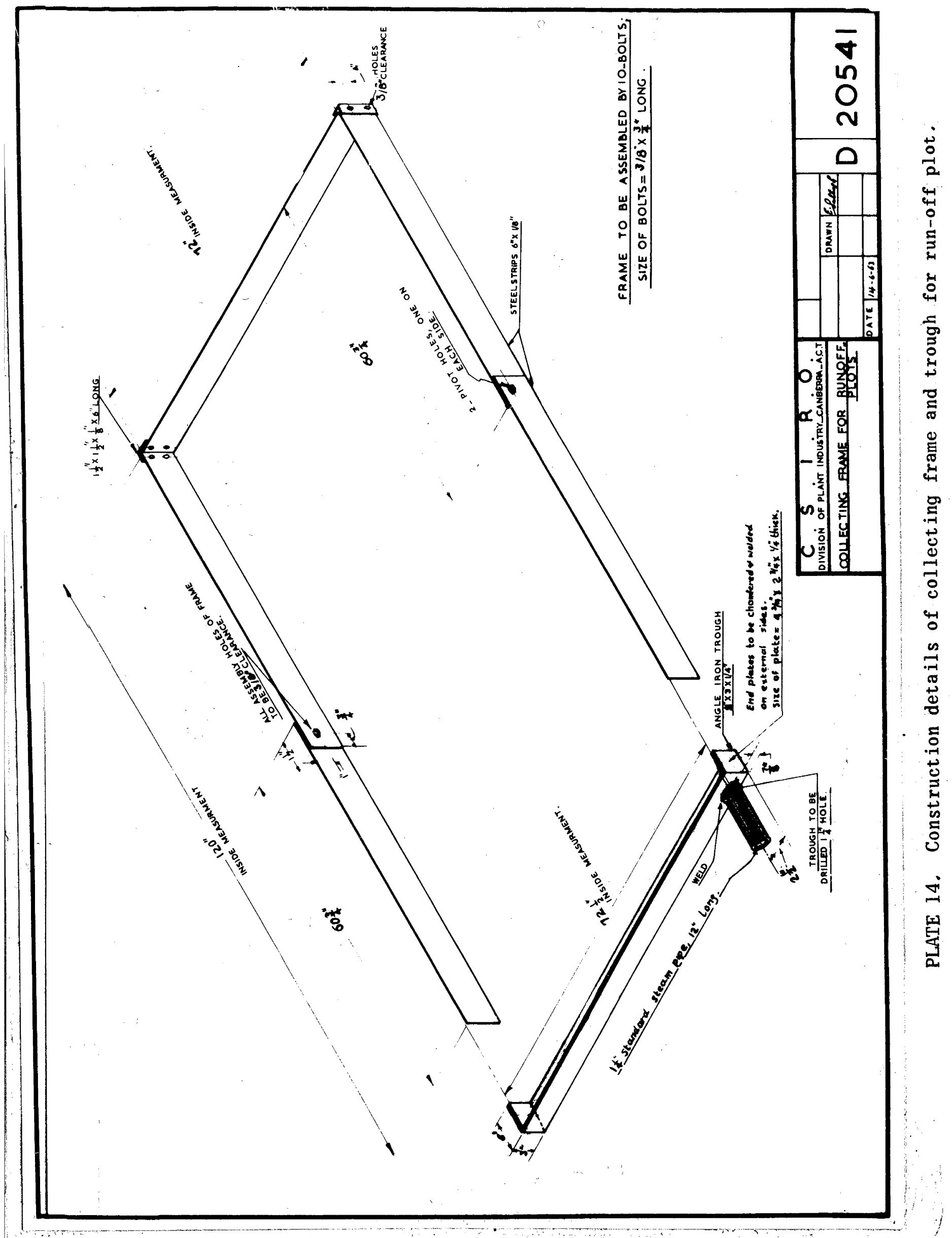




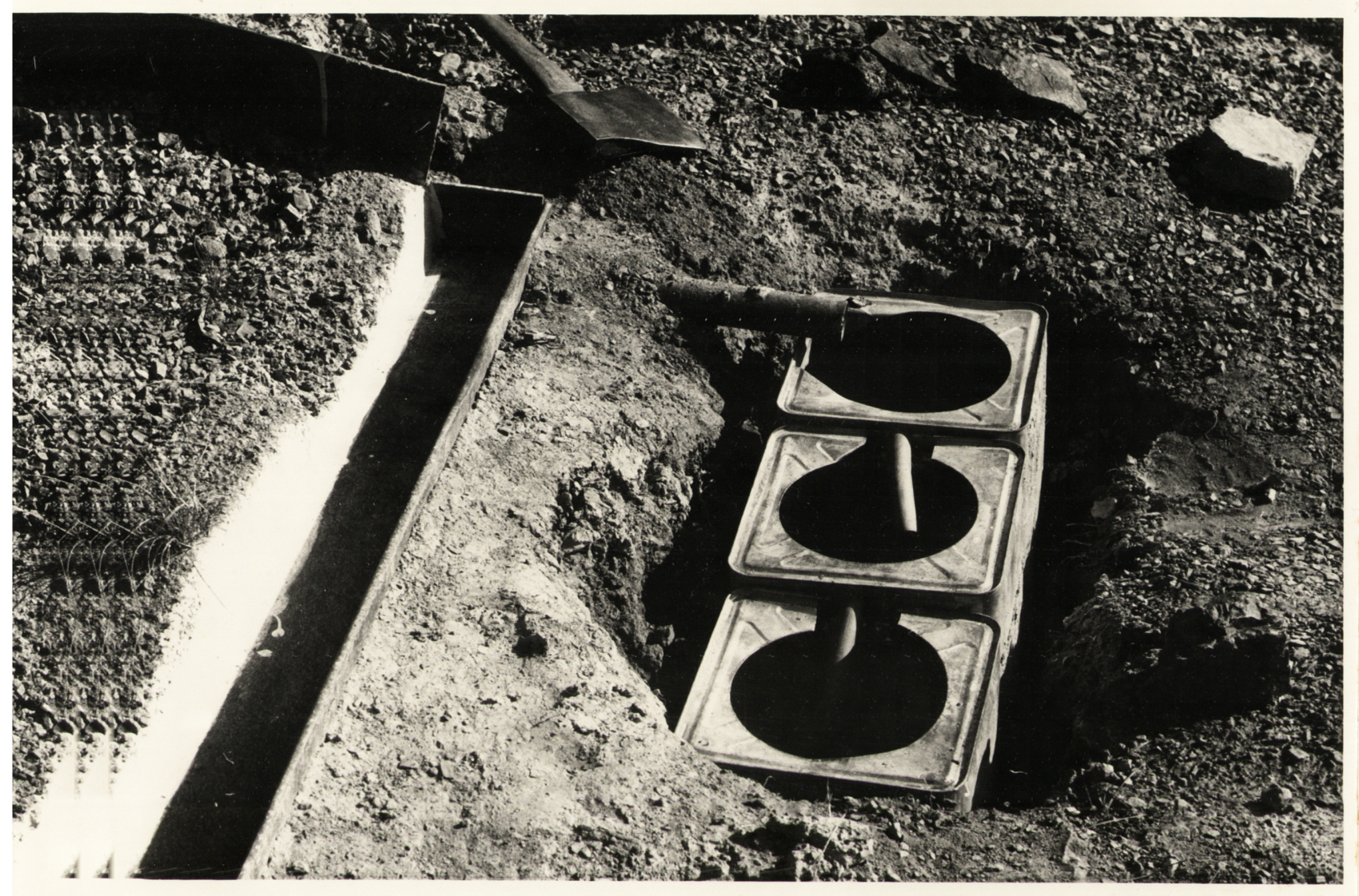

PLATE 15. Base of plot showing concrete covered face to prevent subsurface flow: and collecting tins with overflow pipes. 


\section{(a) Permanent plots}

Forty-one permanent plots were installed during the winter months of 1963. Five were situated in the eucalypts and five in the pines at each of the four sites, and one plot was located on the firebreak between the pines and eucalypts at site A. The plot sites were selected subjectively so that they covered a wide range of ground cover conditions within each site. Four gallon tins were set into the ground at the foot of each plot - one tin for most of the plots, but two or three for plots that showed high values of surface run-off. Where more than one tin was used, a simple overflow mechanism was utilised see Plate 15. The trough and collecting tins were covered with aluminium covered tarred paper to keep out rain. Plate 16 shows a plot complete with cover.

Plastic storage rain gauges were set up at each site to collect total rainfall, and a pluviometer at site $A$ and another at site D (operated by Forest Research Institute) provided data on rainfall intensities. Plate 17 shows the pluviometer at site A with one of the plastic storage gauges.

Immediately after a rainfall。 each plot was visited and the volume of run-off measured. Any soil that had been deposited in the trough was washed into the collecting tins, and soil loss was determined by agitating the run-off water in the tin and taking a subsample (300 c.c.) which was later oven dried and weighed. The soil from the subsample was accumulated during the year for each plot and chemical analyses carried out. 


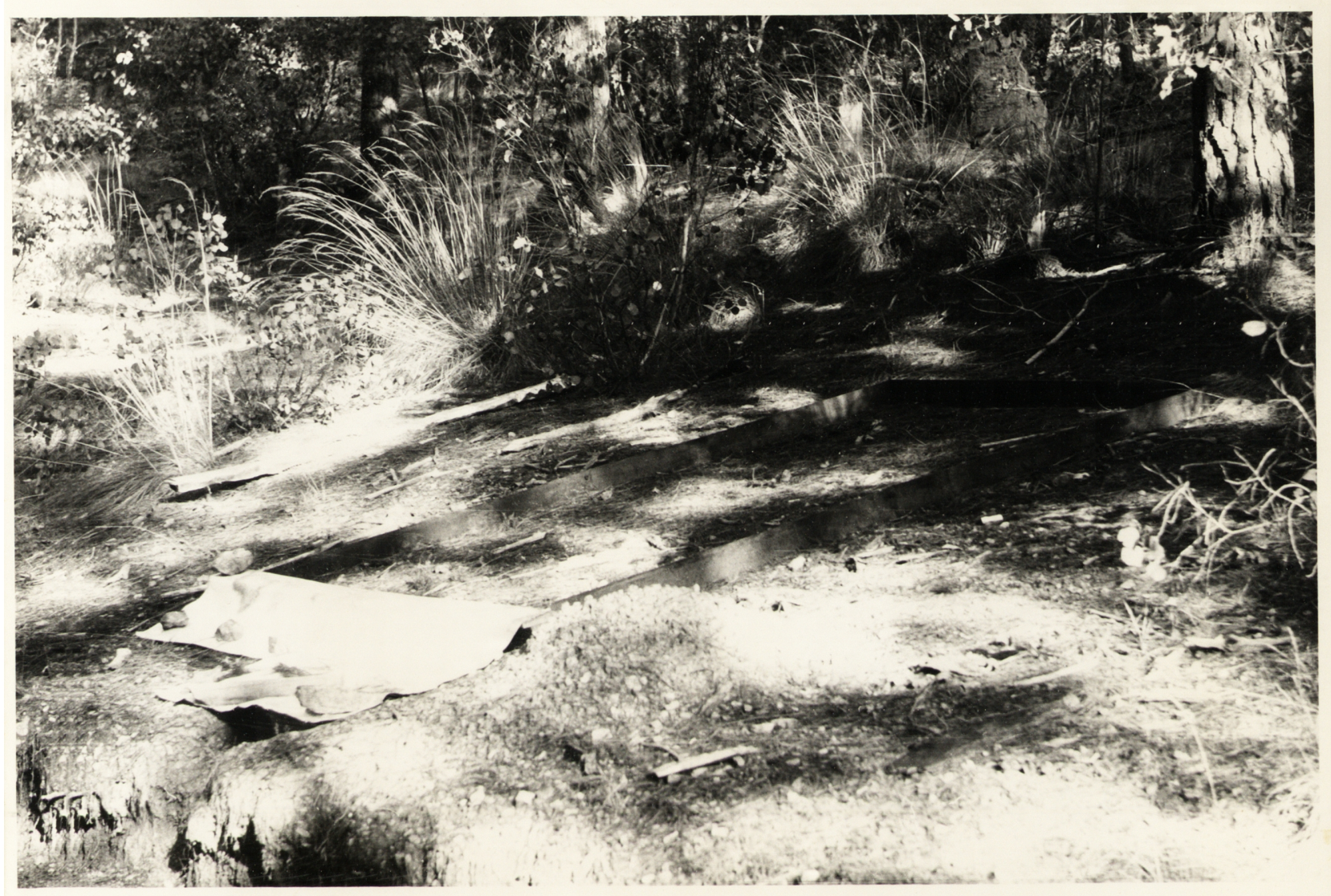

PLATE 16. ' Installed plot with protective covering over trough and collecting tins. 


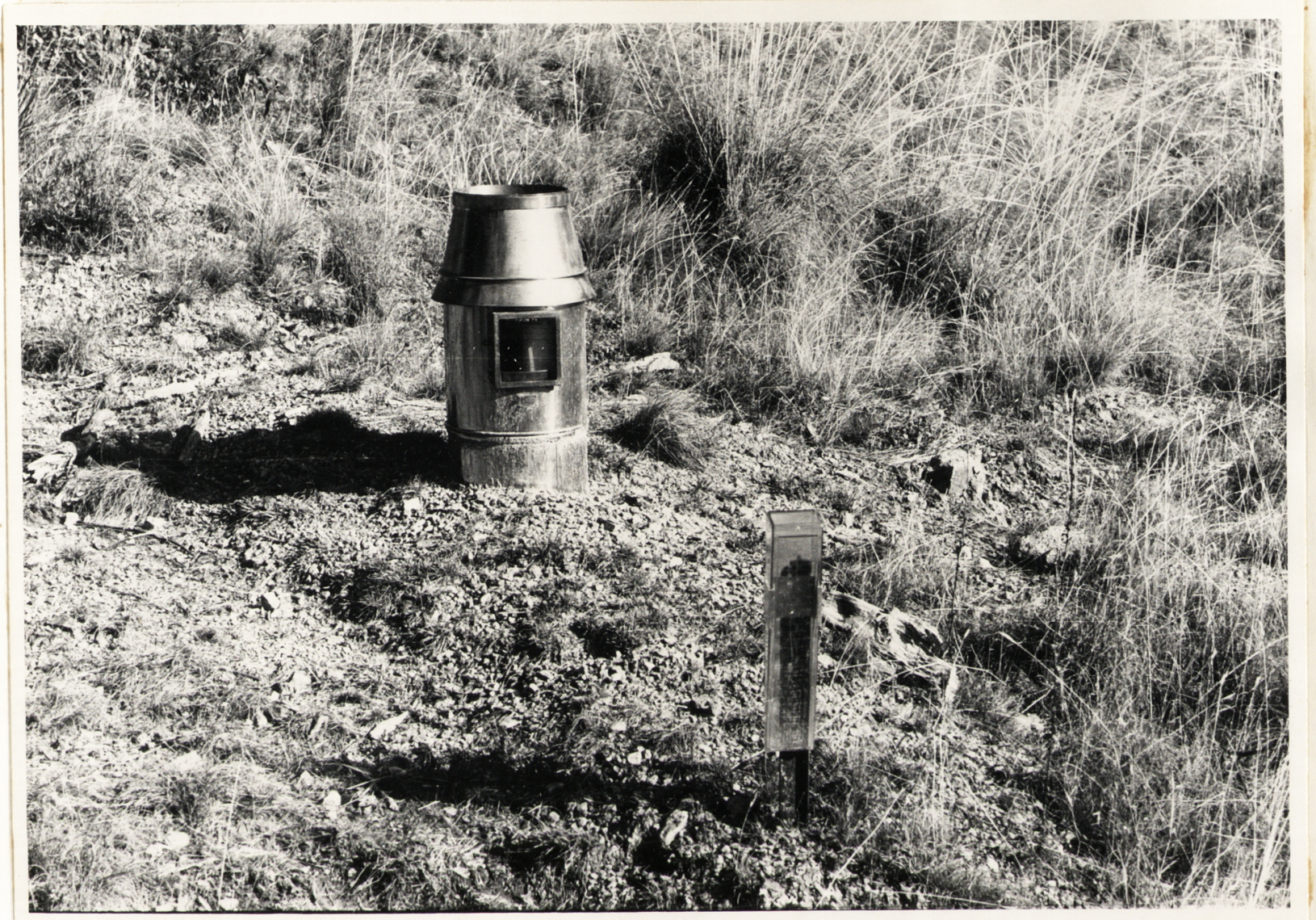

PLATE 17. Siphon type pluviometer and plastic storage gauge at site A. 
During periods of very prlonged or intense rainfall, some of the collecting tins overflowed, so it was necessary to estimate the volume of run-off. This was done by plotting the rainfall - run-off data for varying rainfall intensities, and extrapolating. Figure $7^{*}$ shows the situation for plot D9.

At the conclusion of the experiment the percentage cover was estimated using a grid. The ground cover was harvested, sorted into various types (leaf litter, grass, shrubs, bracken fern, sticks and twigs), oven dried at $148^{\circ} \mathrm{F}$. for 48 hours and weighed.

(b) Infiltration measurements

In order to obtain the maximum possible information on the factors affecting infiltration, the permanent plots were supplemented by roving plots so that a wider range of soil-vegetation types could be sampled. It was necessary to design a portable infiltration apparatus so that direct measurements of infiltration could be made.

There are two main methods for the measurement of infiltration in the field. The first utilizes small rings which are generally driven into the ground, partly filled with water.

The significance level of the correlation coefficient $(r)$ is shown thus:

$$
\begin{aligned}
* & (\mathrm{P}=0.05) \\
* * & (\mathrm{P}=0.01) \\
* * * & (\mathrm{P}=0.001)
\end{aligned}
$$

N.S. indicates that the correlation coefficient is not significant . 


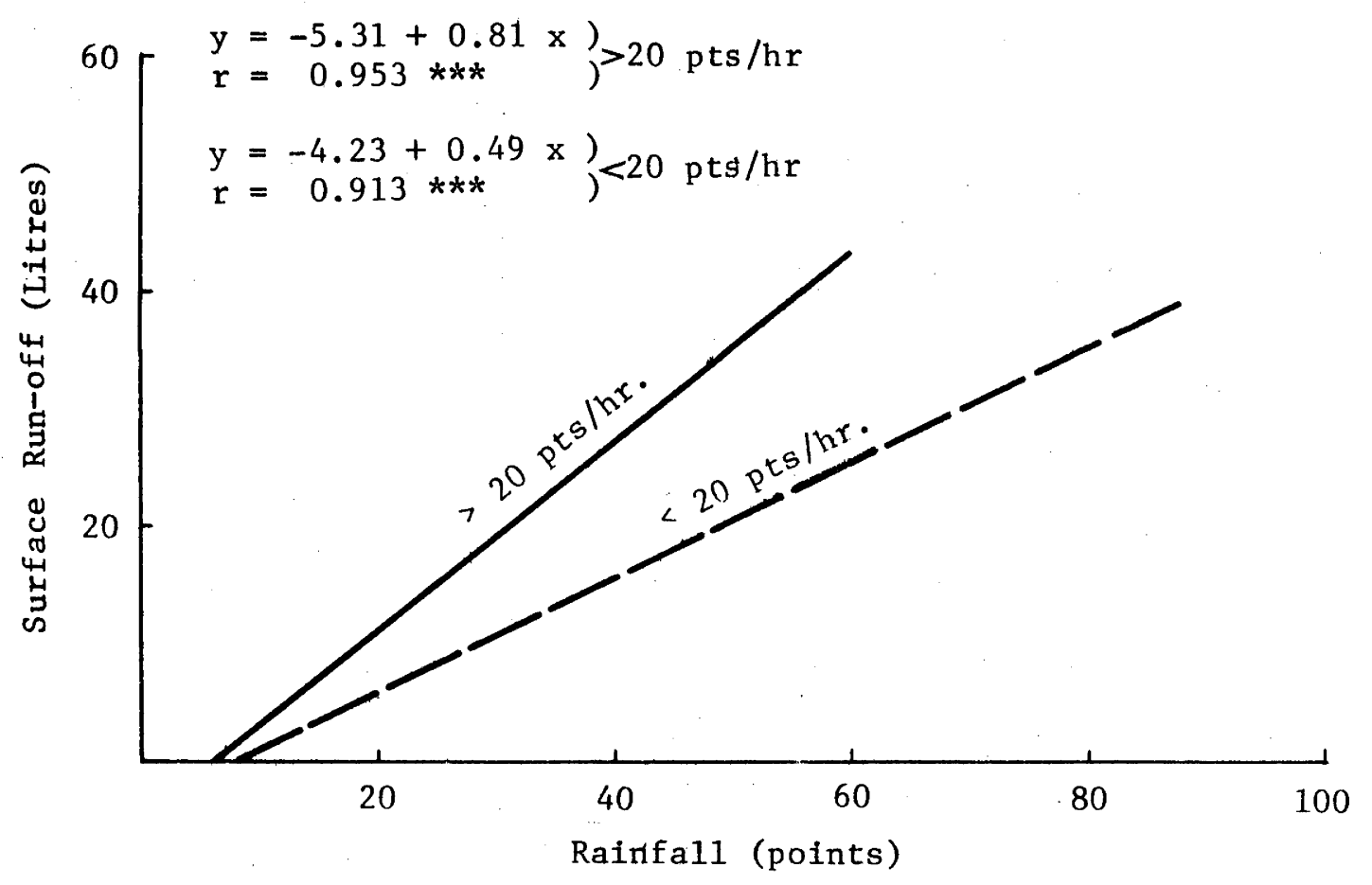

Figure 7. Relation between surface run-off and rainfall for plot $D 9$. 
and the rate of intake into the soil measured. These ring infiltrometers are often unsatisfactory because of the small area sampled and the fact that there is no effect of raindrop action on the soil. However, they have been used extensively, particularly in agricultural areas (e.g. Auten 1933; Musgrave 1935; Marshall and Stirk 1950; Tisdall 1951; Adams et al. 1959). The second method employs a sprinkling device which applies water to a plot at an even rate. The rate of surface run-off can be determined and, by subtracting this value from the rainfall rate. an estimate of the infiltration rate is obtained. This method has the added advantage of providing information on soil loss during the rainfall. These sprinkling types have also been used extensively (e.g. Craddock and Pearse 1938; Arend and Horton 1943; Wilm 1943; Woodward 1943; Packer 1951, 1953; Orr 1957; Dortignac and Love 1961).

A sprinkling type was considered most suitable for the measurement of infiltration in the present study. The equipment had to be compact anth easily handled by one person on steep terrain, and none of the types described in the literature met these requirements.

The equipment finally developed is described below. The water was carried in 44 gallon drums, which were calibrated in points of rainfall (per the plot area of 60 square feet) by an outside manometer (see Plate 18). It was possible to read this manometer to the nearest half point of rainfall, which was satisfactory accuracy for this type of work. The water was 


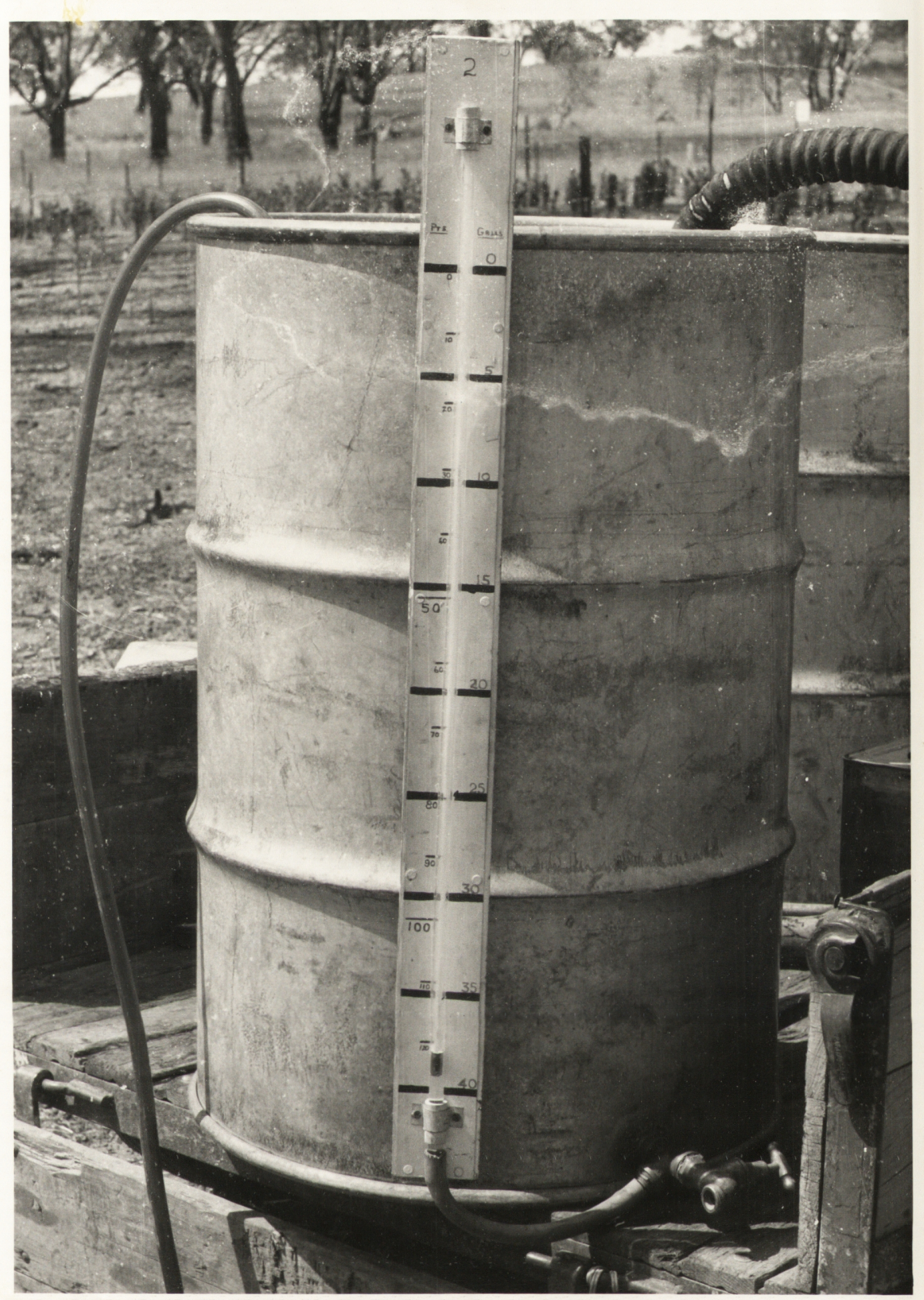

PLATE 18. Forty-four gallon drum with manometer calibrated in points of rainfall per the plot area of 60 square feet. 
pumped from the drums through a $1 \frac{1}{2}$ " wire reinforced hose by a 3/4" centrifugal pump with by-pass valve; driven by a 2 horsepower engine at 1,500 r.p.m. The pump and engine were fitted into a unit with a wheel and two handles to make for easier handling in the field - see Plate 19. The water was delivered to the plot through a $1 / 2$ " garden hose and a 3/8" copper boom, and the delivery rate was governed by a tap at the base of the boom - see Plate 20. Before beginning watering the drum was levelled with a spirit level.

Some difficulty was experienced in selecting a nozzle with a combination of suitable drop size distribution. area of spread and rate of delivery. This is not an uncommon problem in infiltration work; nozzles which produce the desired drop size distribution produce abnormally high intensities (Smith 1964). Many nozzles were tested, and the one finally selected is shown in Plate 21. It is a commercially manufactured rose spray with an orifice diameter of $1 \mathrm{~mm}$. Two of the inner rings of holes were soldered up to reduce the rate of delivery. The drop size distribution was found by moving the sprinkler across pans of finely sieved flour (Laws and Parsons 1943). The drops hardened into dough pellets which corresponded very closely in size to the raindrops that made them. The pellets were left overnight to harden, then sieved into size fractions. Figure 8 shows the drop size distribution curve for the nozzle for a rainfall intensity of 320 points per hour and Plate 22 shows the typical size ranges. The median diameter was $1.3 \mathrm{~mm}$, 


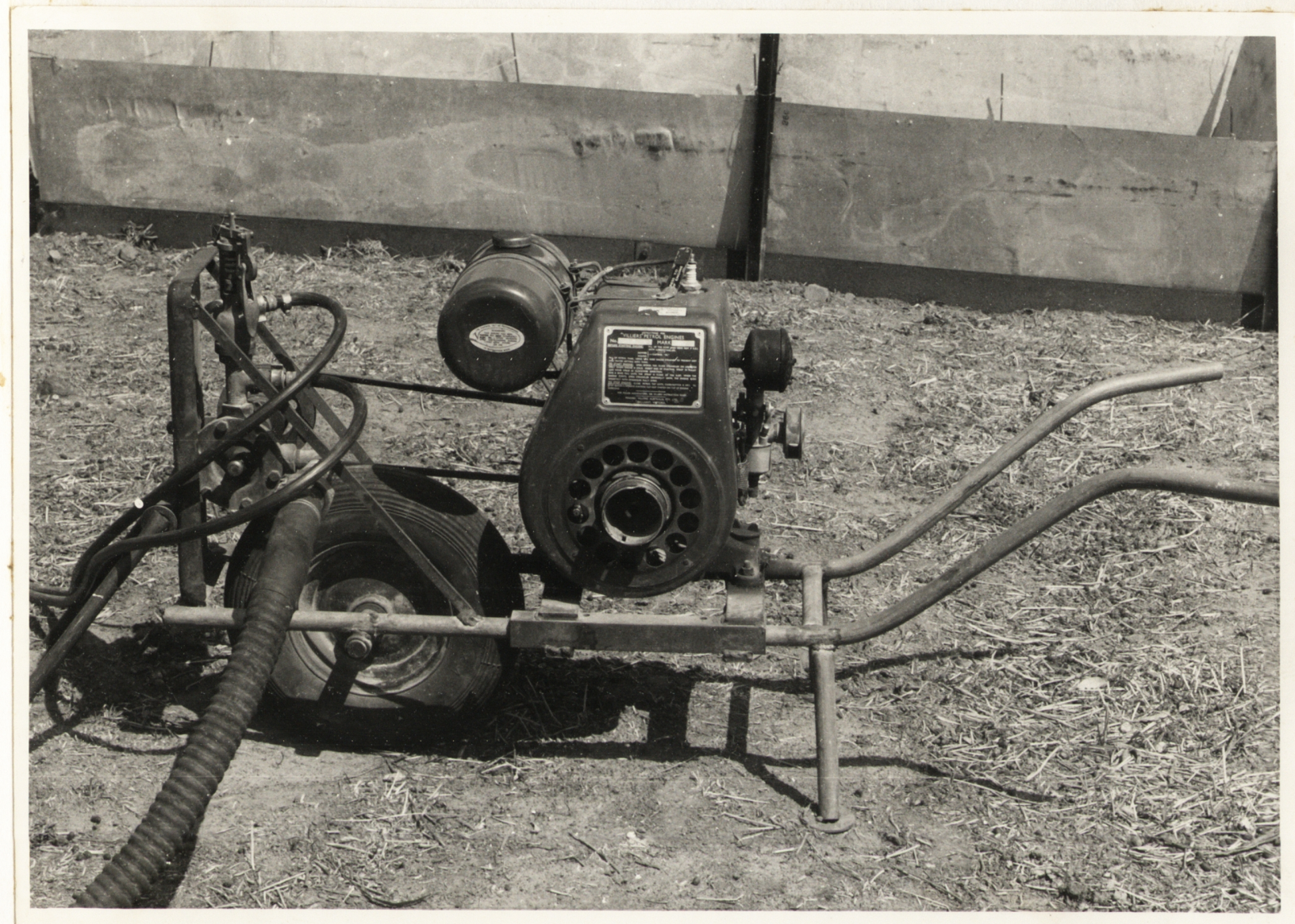

PLATE 19. Two horse power engine and 3/4" centrifugal pump used to deliver water to the plots. 


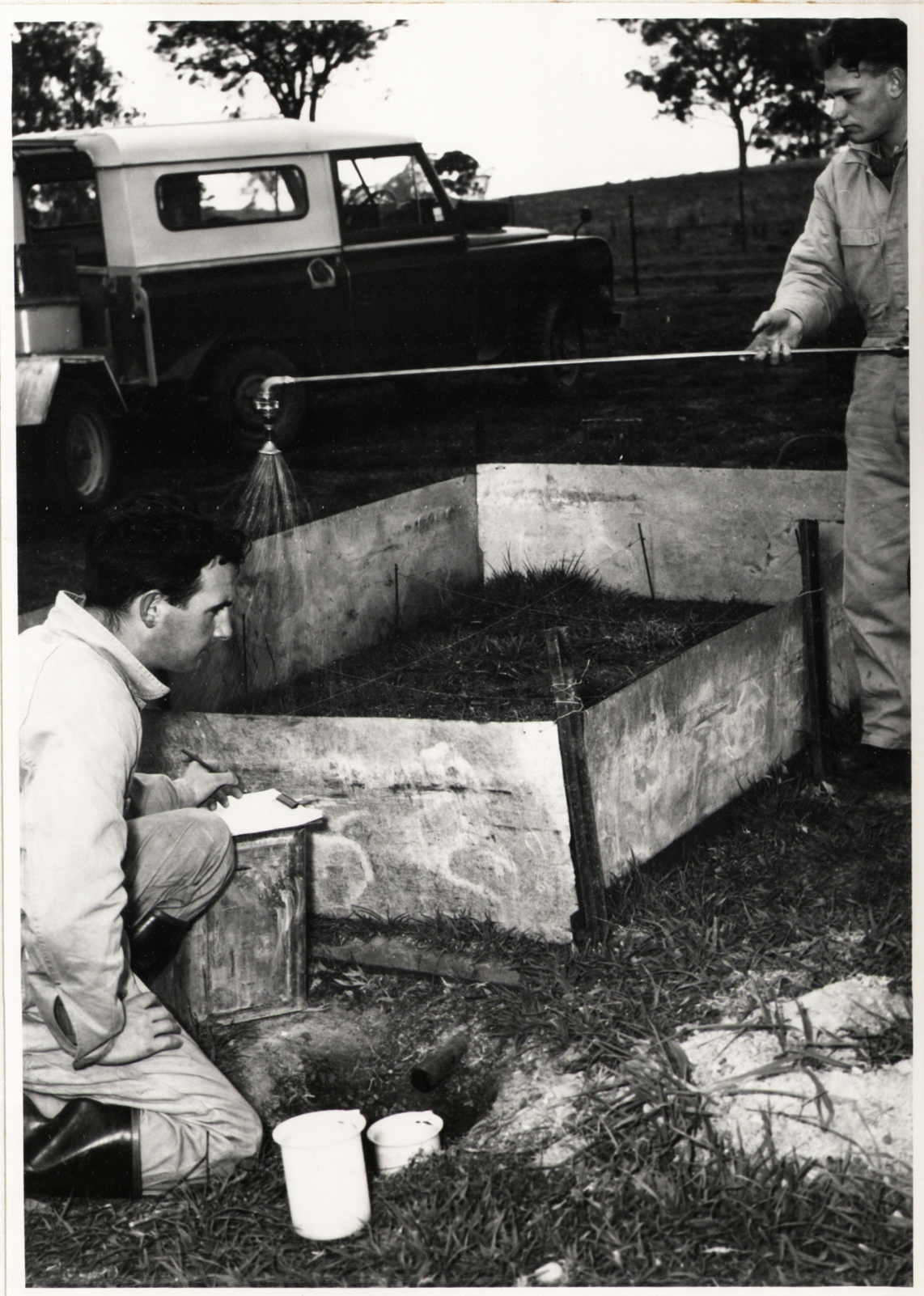

PLATE 20. Method of applying artificial rainfall using copper boom with tap at base to govern rate of application. 


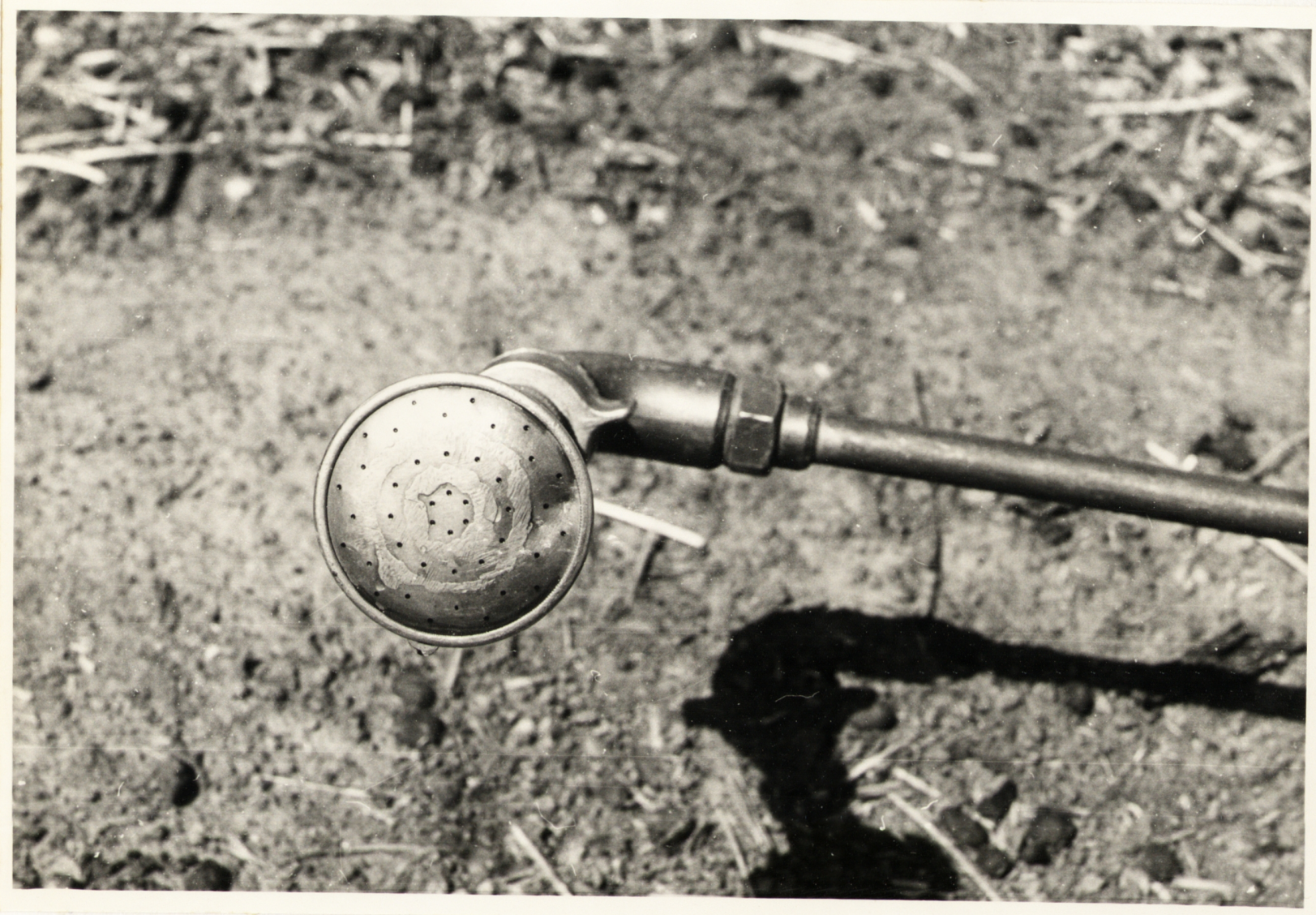

PLATE 2l. Rose spray used in experiments showing two soldered rings of holes. 
$-14 d-$

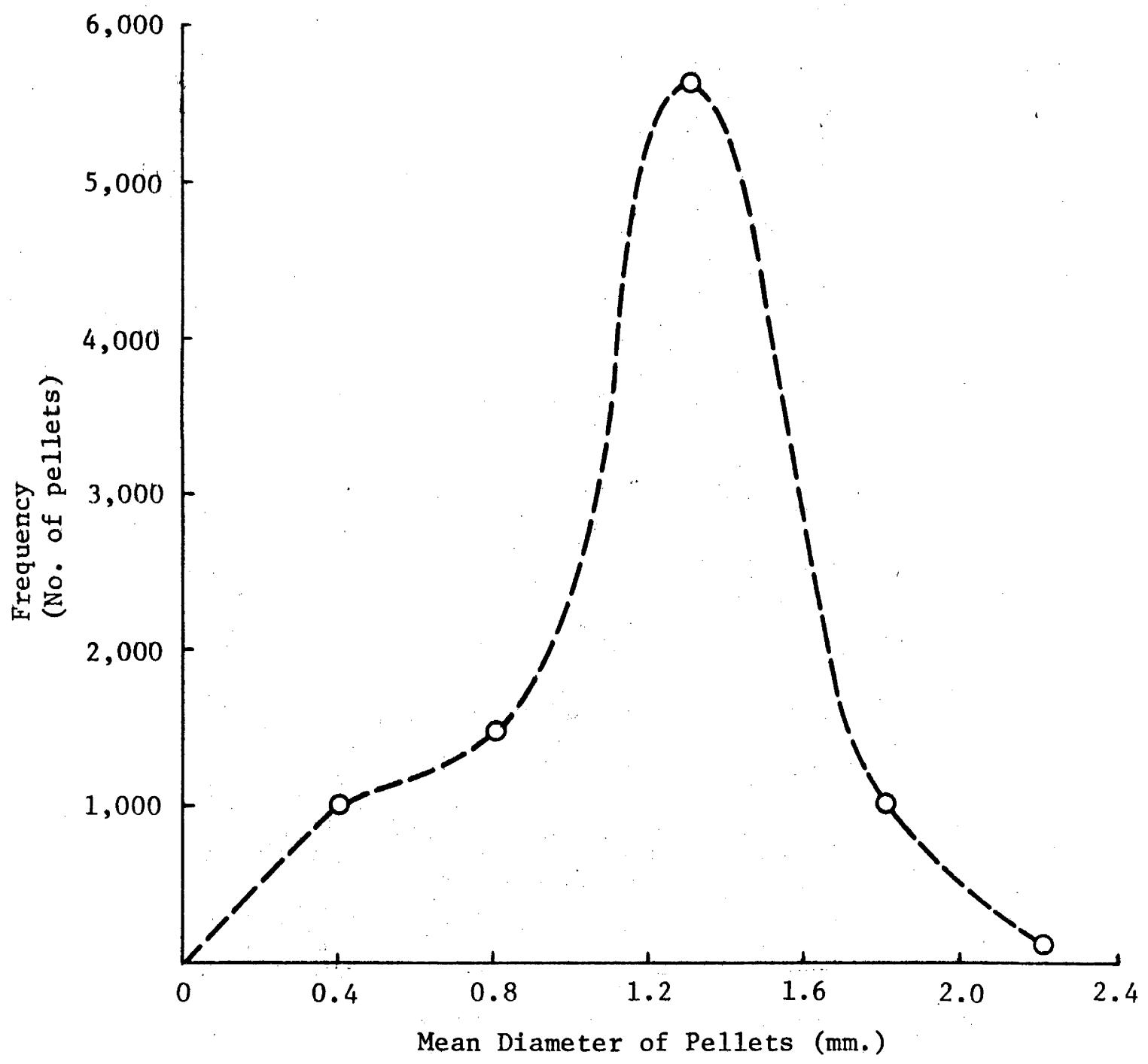

Figure 8. Size distribution curve for artificial raindrops. 


\section{S I M U LAT E D R A I NFA L L}
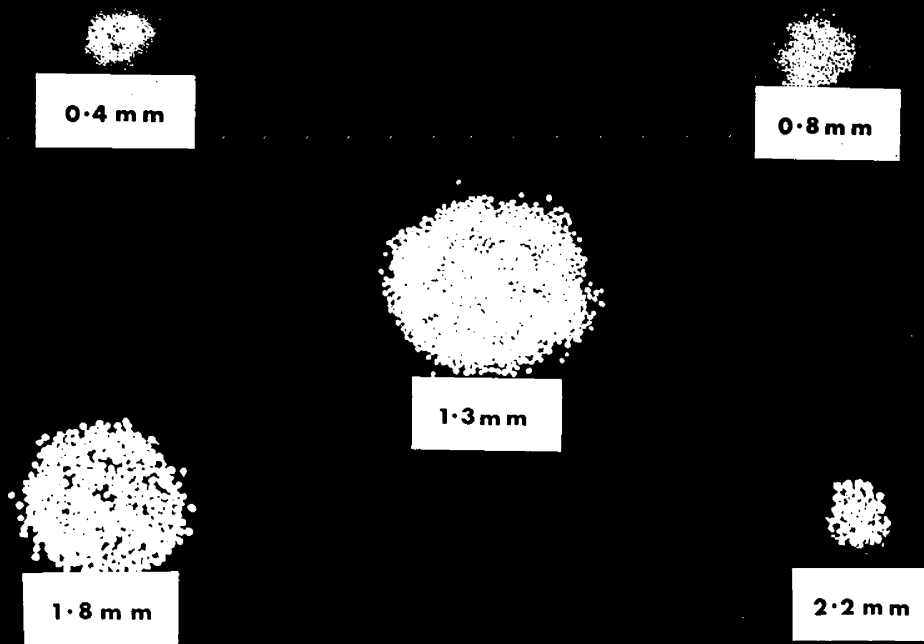

\section{ME A N \\ D I A M E T E R \\ O F \\ P E L L E T S}

PLATE 22.' Size range of pellets formed by moving sprinkler across pans of flour. Diameters are the mean of size classes. 
and this was somewhat conservative when compared with drop sizes for natural rainfalls of similar intensities; e.g. Laws and Parsons (1943) found a median drop size of $3.0 \mathrm{~mm}$ for rainfall of 400 points per hour intensity; and Smith and Smith (1950) found a median drop size of $2.5 \mathrm{~mm}$ for an intensity of 320 points per hour.

The initial velocity of emergence was determined by the simple method described by Meyer (1958) of turning the nozzle to discharge upwards and measuring the mean height of rise " $h$ " of the drops, and substituting in the formula:

$$
\begin{aligned}
& V^{2}=V_{0}^{2}+2 g h \\
& V \text { (velocity at height } h \text { ) }=0 \\
& V_{0}=\text { initial velocity of emergence } \\
& g=\text { retardation due to gravity } \\
& h=\text { mean height of rise of raindrops }
\end{aligned}
$$

The effects of air resistance are disregarded in this equation, but it is considered to be accurate enough to give a rough idea of the initial velocity. The mean height of rise was found to be 7.5 feet and the calculated initial velocity 22 feet per second. Terminal velocity of the drops was then calculated using a vertical distance of fall of three feet (height of nozzle above ground during normal application) and the above value of initial velocity. The terminal velocity was found to be 26 feet per second. This figure agrees very well with the terminal velocity of natural rain of similar intensities: e.g. Smith and Smith (1950) give a value of 25 feet per second 
for a rainfall intensity of 320 points per hour and Wischmeier and Smith (1958) give a value of 26 feet per second for a drop size of $3.0 \mathrm{~mm}$ (which corresponds to 400 points per hour from the data of Laws and Parsons).

The drops had a somewhat smaller diameter than those of similar intensity natural rainfall, but a slightly higher terminal velocity. In general, it was felt that the drop size and velocity characteristics of the simulated rainfall were very satisfactory .

The water was applied to the plots manually by moving the boom back and forth over the plot. It was necessary to find a method of application which resulted in an even spread of water over the plot. The plot was divided into 60 squares (each $1 \mathrm{ft} \times 1 \mathrm{ft}$ ) with a string grid, and a small beaker placed at the corner of each square. Different methods of application were tried until one was found which did not result in any bias in application (as measured by the volume of water deposited in the small beakers). The method (shown in Figure 9) was then adhered to for all field experiments. To assist in application in the field, the plot to be watered was divided into 12 even areas by a string grid (Plate 23). Metal wind shields were erected round the plot to prevent the spray from being deposited outside the plot frame (Plate 23).

When the rainfall rate exceeded the infiltration rate, surface run-off began, and the water was directed into a beaker. When the water reached a marked level it was exchanged for another 
$-16 a-$

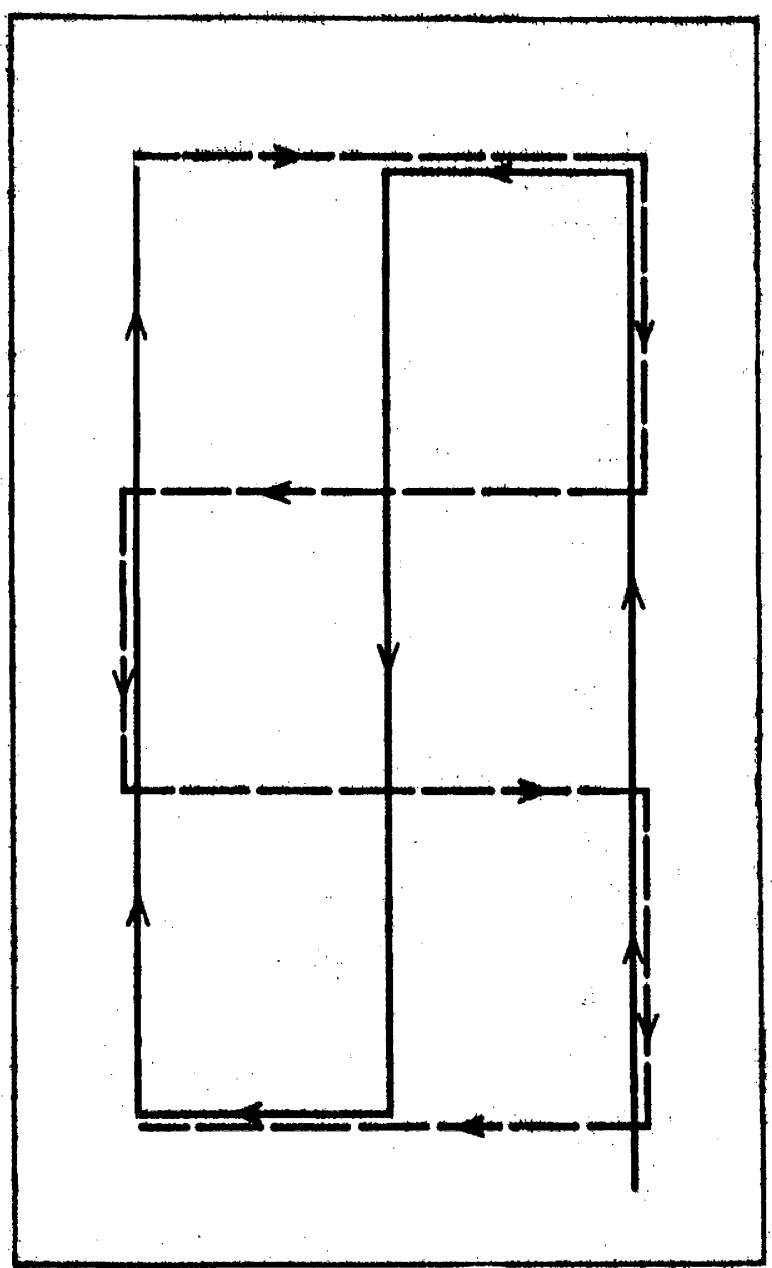

Figure 9. Method of applying artificlal rainfall to plot - arrows indicate direction in which boom was moved so that no bias in application occurred. 


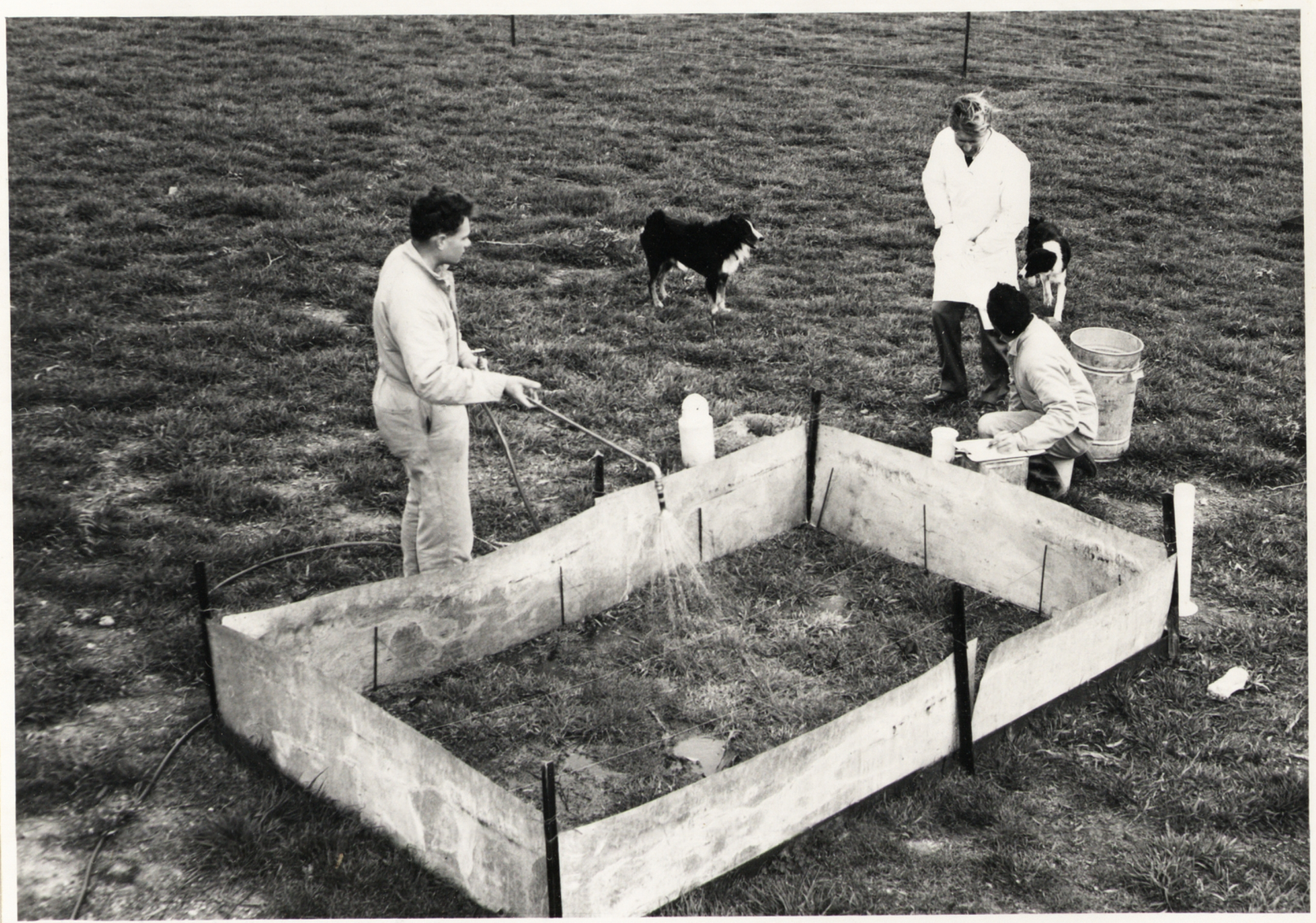

PLATE 23. Infiltration run in progress showing wind shields and string grid. 
beaker of the same size, and the time noted (Plate 24). The rate of run-off could thus be calculated; and subtracted from the rate of rainfall to give the infiltration rate. The infiltration rate generally reached a constant value after about 5-7 minutes from the onset of the rainfall, and the infiltration results expressed in this study refer to this constant rate (designated fc.). The run-off water from each plot was bulked and subsampled for soil loss.

The rate of rainfall used on all plots was 80 points in 15 minutes. This was a convenient rate for the equipment to handle and was not unlike some of the high intensity falls which the catchment has received. On the basis of rainfall records from Fairbairn Meteorological Station it was found that during an eight year period (1955-1963) seven falls in excess of 60 points in 15 minutes had occurred. Although the rainfall rate used in the experiments was somewhat higher than that normally expected, it was a suitable one to simulate stress conditions. In addition, the infiltration rate of many areas was found to be close to or greater than this rate ( 80 points in 15 minutes) so a lower rate would have provided results which, would have been difficult to interpret.

Two infiltration runs were generally carried out, a dry run when the soil and vegetation were dry, and a wet run on the following day. The object of the dry run was to wet the surface soil so that when the wet run was carried out the surface soil had drained to about field capacity. This ensured that wet run results from different plots would be comparable. In 


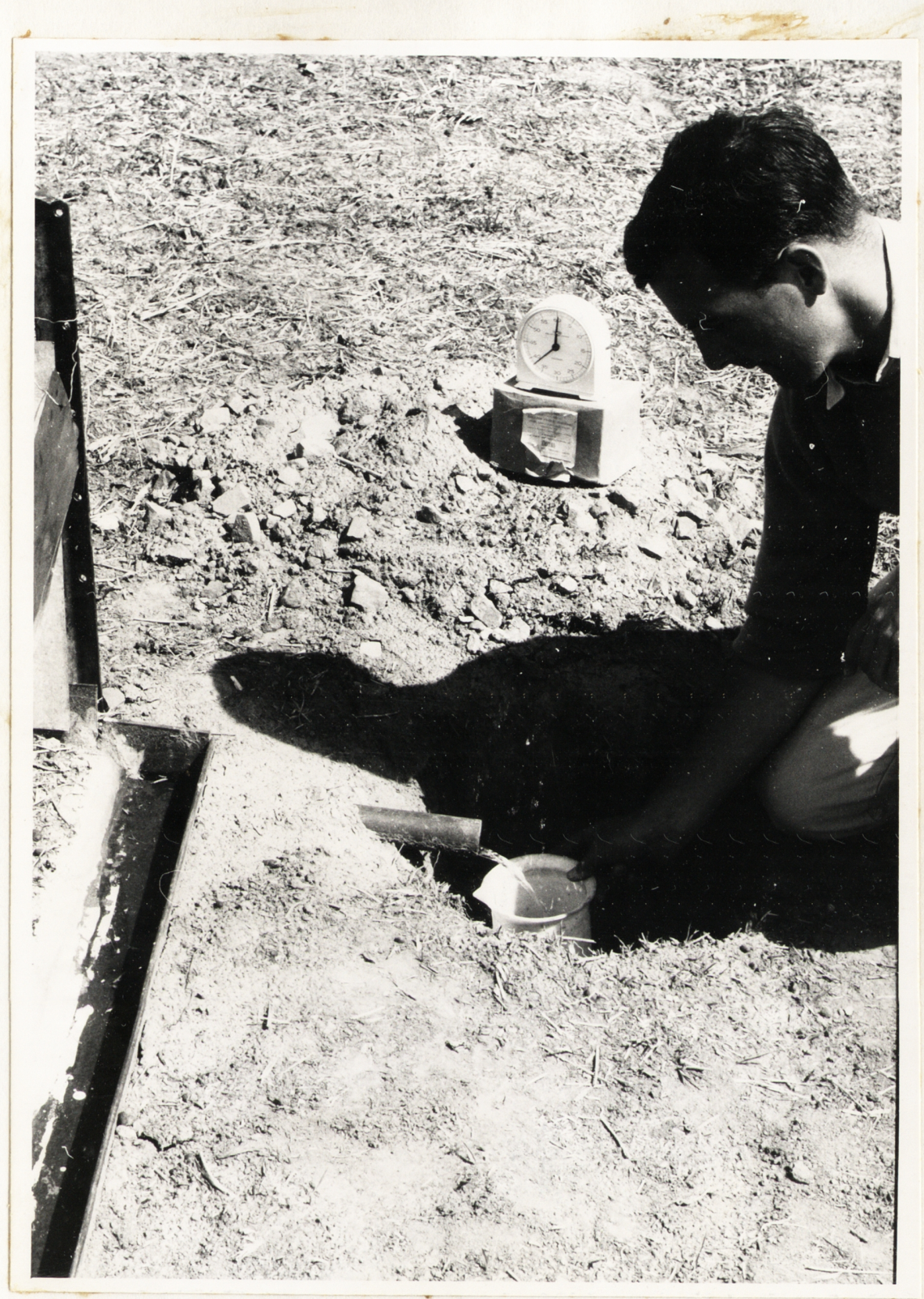

PLATE 24. Method of measuring rate of run-off. 
some cases the ground cover was harvested after the wet run and a bare run carried out.

Plates 23 and 25 show the operation of the equipment on typical infiltration runs.

(c) Prescribed burning experiment

Prescribed burning as a technique for reducing fire hazard has received considerable attention lately and its use as a management tool has become widespread. Most applications of prescribed burning have been in native eucalypt forest, but attention has recently turned to its use in pine plantations. Large areas of pine plantations occur in water catchments, so it is desirable to investigate the hydrological consequences of such practices under plantation conditions.

An area was selected in a 1941 plantation of Pinus radiata at Stromlo Forest, about six miles west of Canberra (site G). The trees had been pruned to eight feet and slash piles were common on the forest floor. The litter layer was well developed and all other vegetation had been excluded from the fớrest floor by dense shading from the canopy. The average measured weight of fine fuel (included slash piles) was $4.970 \mathrm{~g}$ per 60 square feet, which was equivalent to 3.6 tons per acre. Eight plots were installed and two infiltration runs (pre burn dry and wet runs) were carried out on consecutive days. Five days were allowed to elapse after the wet run, then a low intensity prescribed burn was carried out ${ }^{*}$. The fire (shown in 


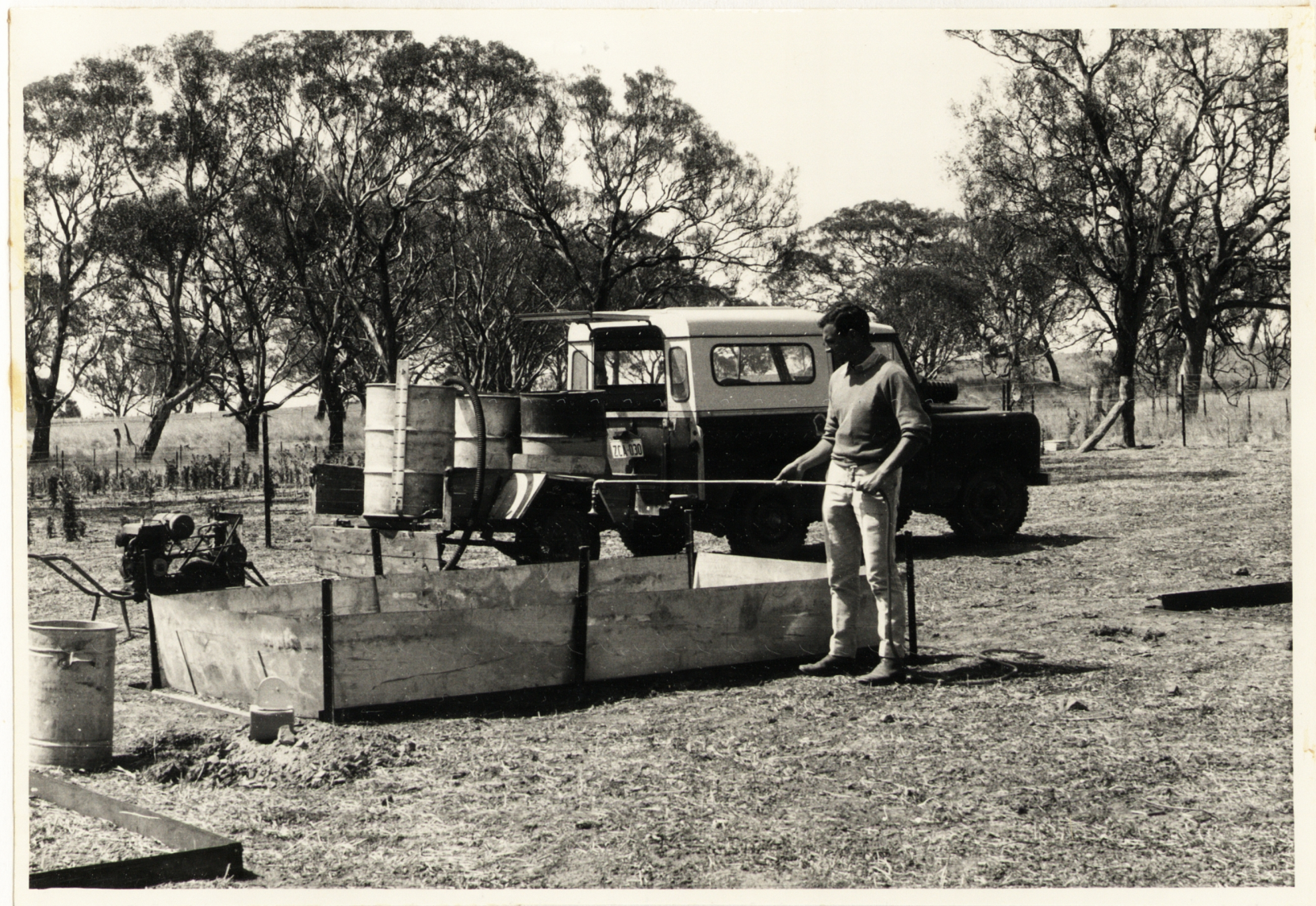

PLATE 25. Typical arrangement of equipment during an infiltration run. 
Plate 26) burnt about half an acre including the area contained by four of the plots. The remaining four plots were kept as a control. On the two days following the fire two more infiltration runs were carried out (post burn dry and wet runs).

A subsample of the run-off water from each of the control plots and from exach of the treated plots was analysed for nutrient content (see Section 4(e) of this chapter for details).

After the infiltration runs the ground cover was harvested from all plots, sorted into fine and heavy fuel, oven dried (at $148^{\circ} \mathrm{F}$ for 48 hours) and weighed.

(d) Revegetation of a firebreak

Wilthin the Cotter catchment there is a considerable network of roads and firebreaks, much of which is graded periodically. Many of these roads and firebreaks show evidence of erosion and. excessive surface run-off, and they could adversely affect catchment values.

It was therefore decided to investigate the effects of revegetating a firebreak on soil and water losses. The clovers, especially white clover ( $\underline{\text { Trifolium }} \underline{\text { repens }}$ ), seemed to hold promise as they can be easily maintained with fertilizer treatments. They are low growing and probably would not produce an excessive amount of dry fuel which could be a danger during the fire season. Further, rabbits and marsupials would remove a considerable portion of the leaf material thereby preventing the accumulation of excess fuel. 


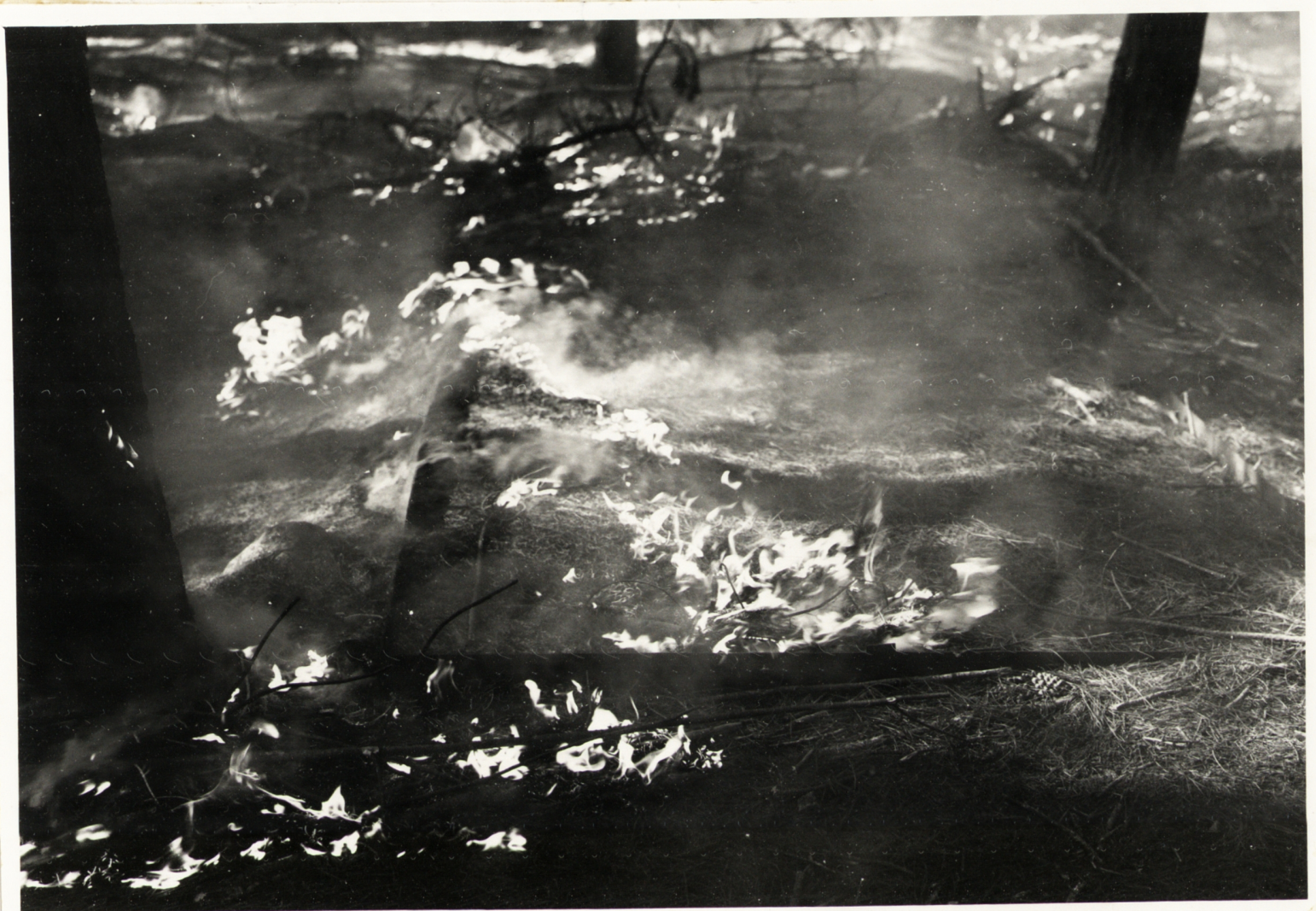

PLATE 26. Low intensity fire used in prescribed burning experiment. 
A section of bare firebreak was chosen in Pierce's Creek Forest (site F) and portion of it sown with a mixture of inoculated subterranean and white clovers (T. subterraneum and T. repens). A blanket dressing of superphosphate was applied at the rate of $2 \mathrm{cwt}$ per acre and four levels of lime were applied. The seed bed was harrowed (or jaked on the steeper portions), the seed sown by hand and the soil raked again to cover the seed.

Sowing was carried out in mid-April 1964 and the seed germinated quickly. However, severe frosts were enountered in late May and the seedlings remained at the cotyledon stage for several months. The effects of the different lime treatments applied at planting were completely overshadowed by the low temperatures during winter, when soil freezing was a common occurrence.

Severe chlorosis appeared in early June, apparently because the nitrogen supply in the seeds had been exhausted and the soil temperature was too low for efficient nitrogen fixation to be carried out by the root nodules (which had formed). To overcome this deficiency, the seedlings were sprayed with a solution of "nitro green" (calcium ammonium nitrate containing about $20 \%$ of readily available nitrogen). This was effective in overcoming the chlorosis and maintaining the seedlings until the beginning of the spring growing season.

By early September the clover was showing satisfactory growth, and good coverage had been obtained on most of the planted 
area by early November (Plate 27).

Plates 28 and 29 show one of the areas before and after planting.

To test the effect of revegetating the firebreak on soil and water losses, infiltration runs were carried out on planted and unplanted sections of the firebreak. Four plots were installed on a planted area and four on an adjacent unplanted area. Plate 30 shows the layout. Two infiltration runs (a dry and wet run) were carried out in December 1964. After the infiltration runs the ground cover was harvested from all plots, oven dried (at $148^{\circ} \mathrm{F}$. for 48 hours) and weighed.

\section{(e) Soil measurements}

\section{(i) Physical}

The surface soil of each permanent plot was sampled for bulk density (weight per unit volume of oven dry soil). Four samples were taken from each plot site using the "Coile" sampler shown in Plate 31, which sampled a cylinder of soil four inches in diameter and two inches deep. The subsurface horizons were also sampled at each site, but not for each plot. Total porosity was calculated from bulk density using the formula:

$$
\begin{aligned}
\text { Total porosity } & (\%)=100-\frac{\text { B.D. } \times 100}{\text { S.G. }} \\
\text { B.D. } & =\text { Bulk density } \\
\text { S.G. } & =\text { Specific gravity of the soil particles. }
\end{aligned}
$$

The value of 2.6 was used for S.G. because it has been found to show little variation between largely inorganic soils (Wilde and 


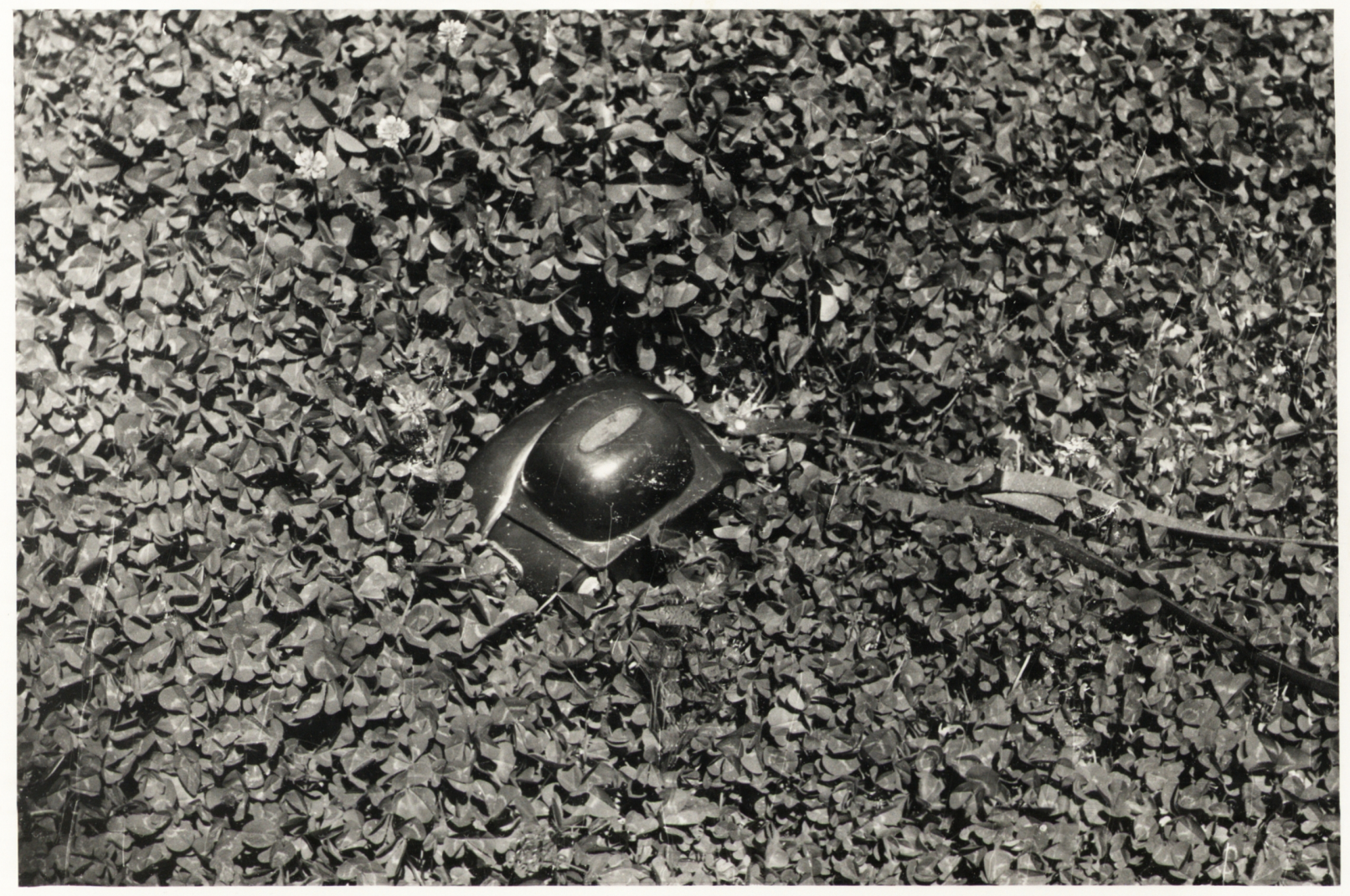

PLATE 27. Dense cover of subterranean and white clover on firebreak at Pierce's Creek. 


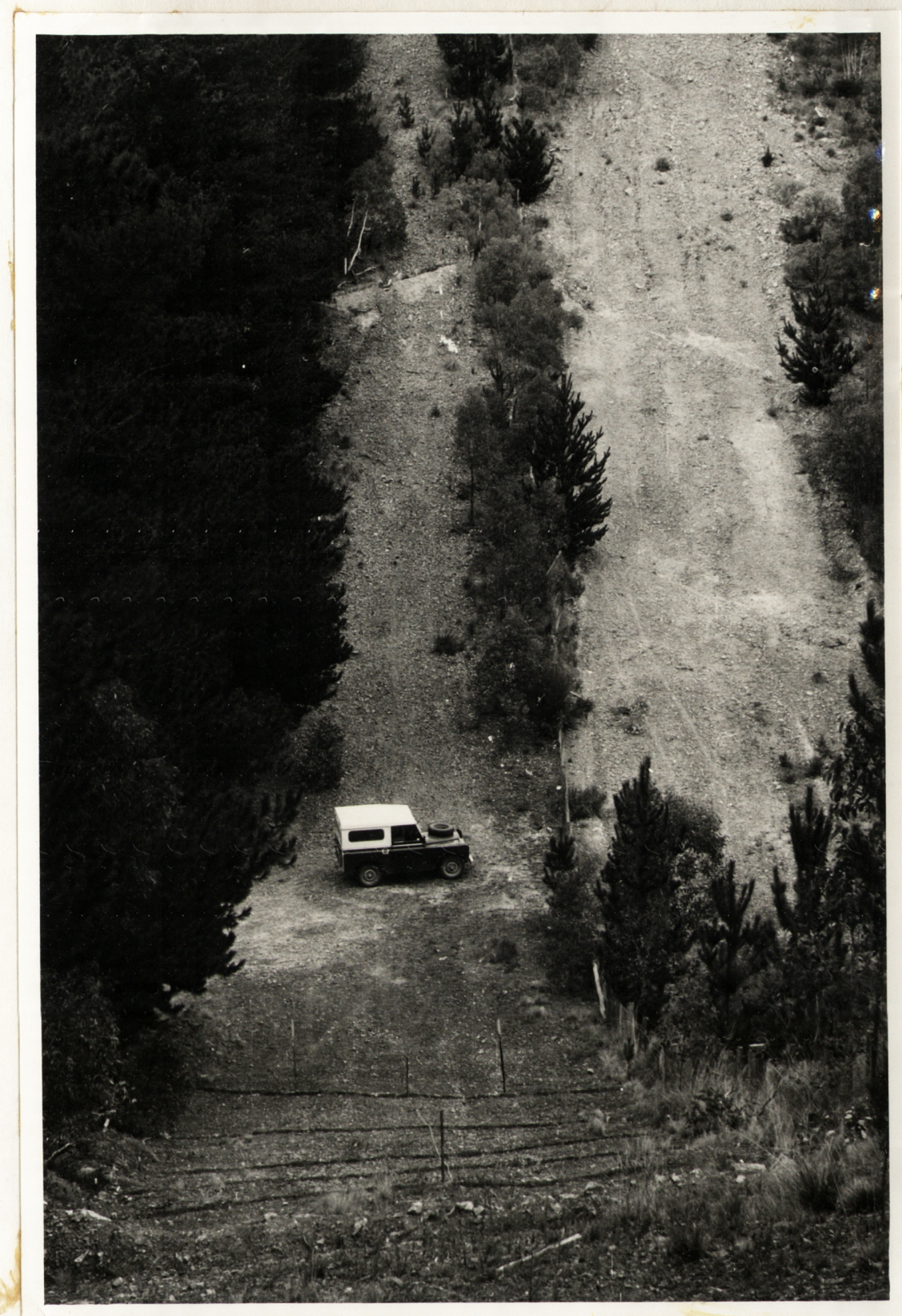

PLATE 28. Steep firebreak at Pierce's Creek before clover establishment. 


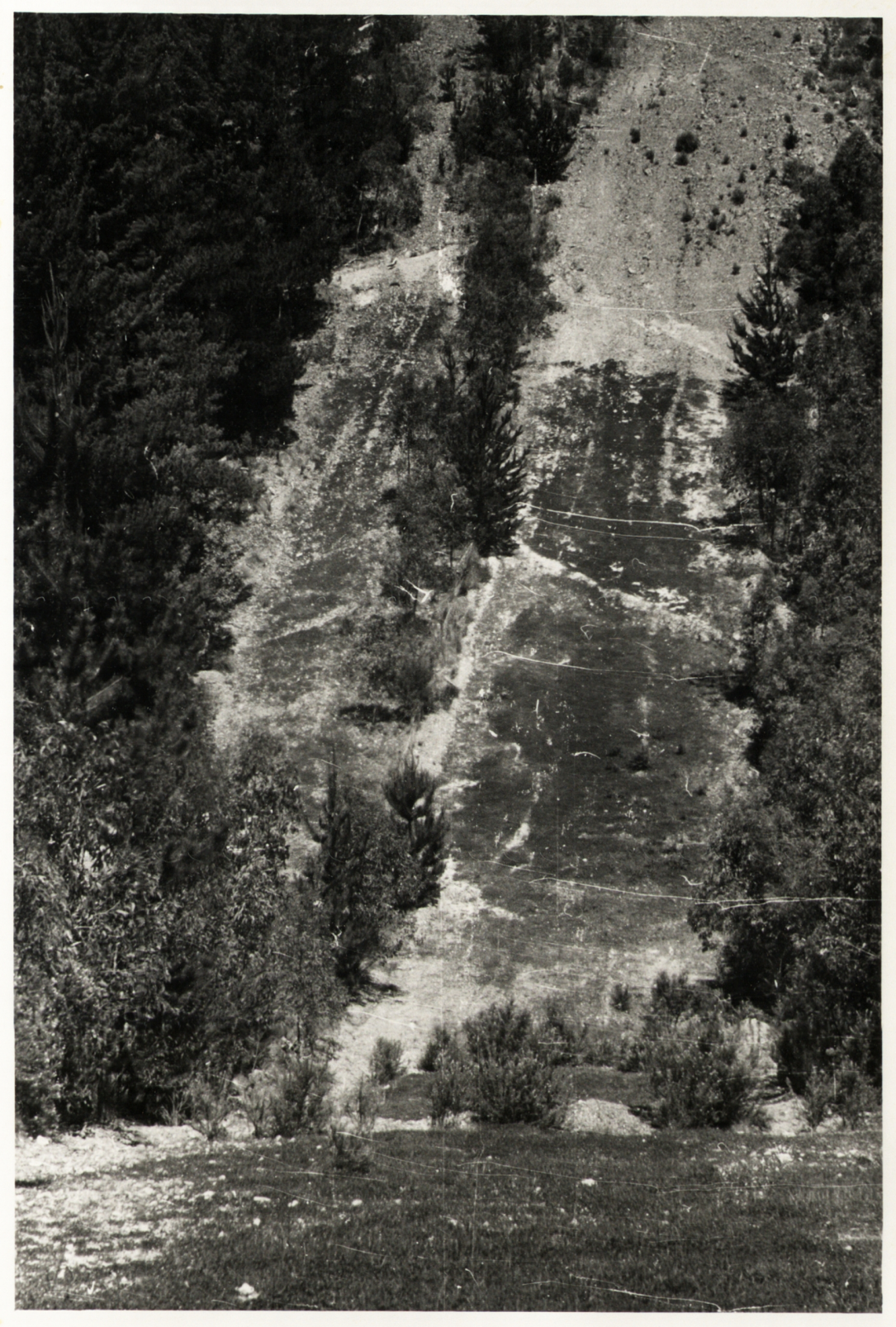

PLATE 29. Same section of firebreak as shown in Plate 28. but after clover establishment. 


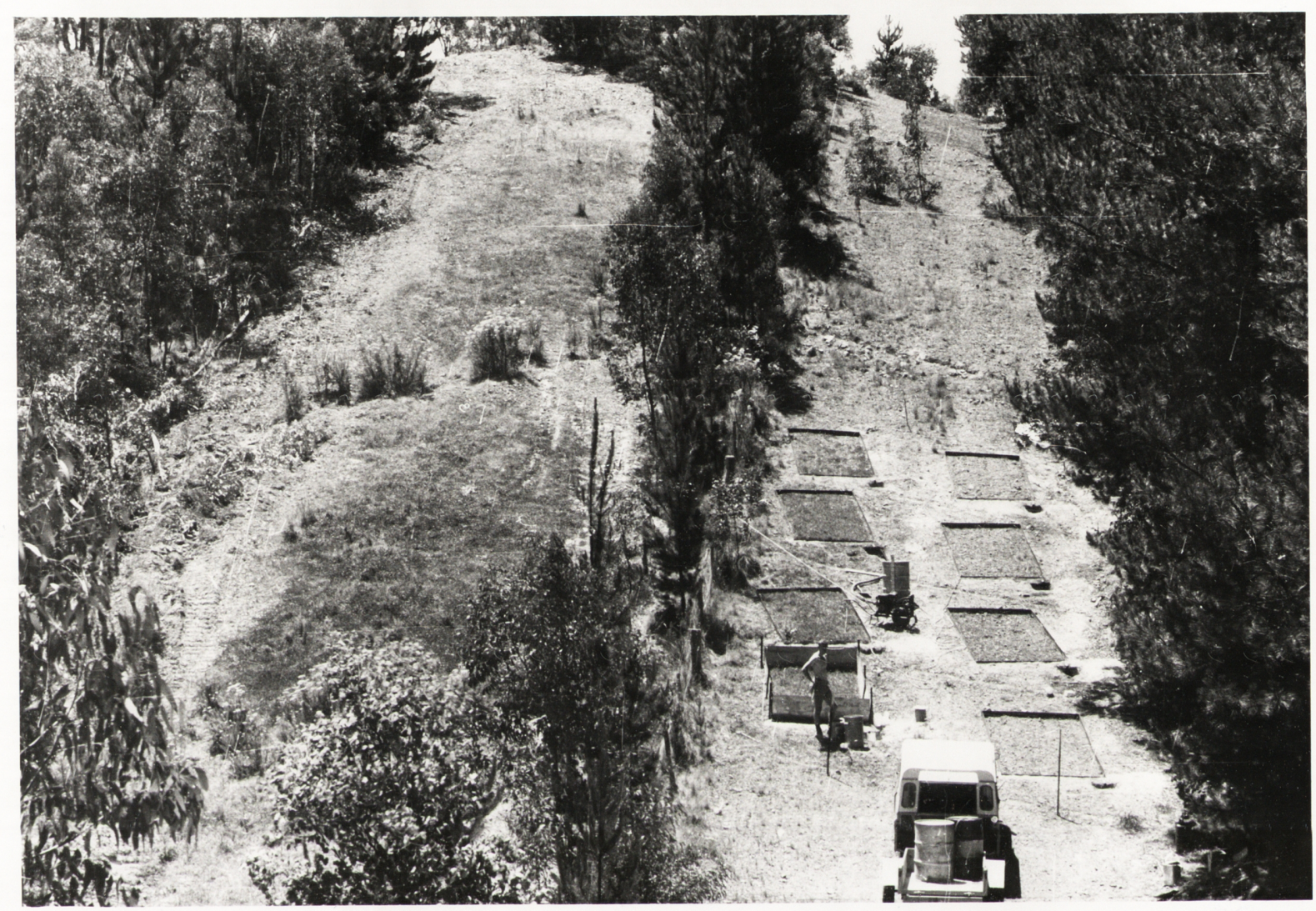

PLATE 30. Arrangement of plots for measuring infiltration and soil loss from planted and unplanted sections of firebreak. 


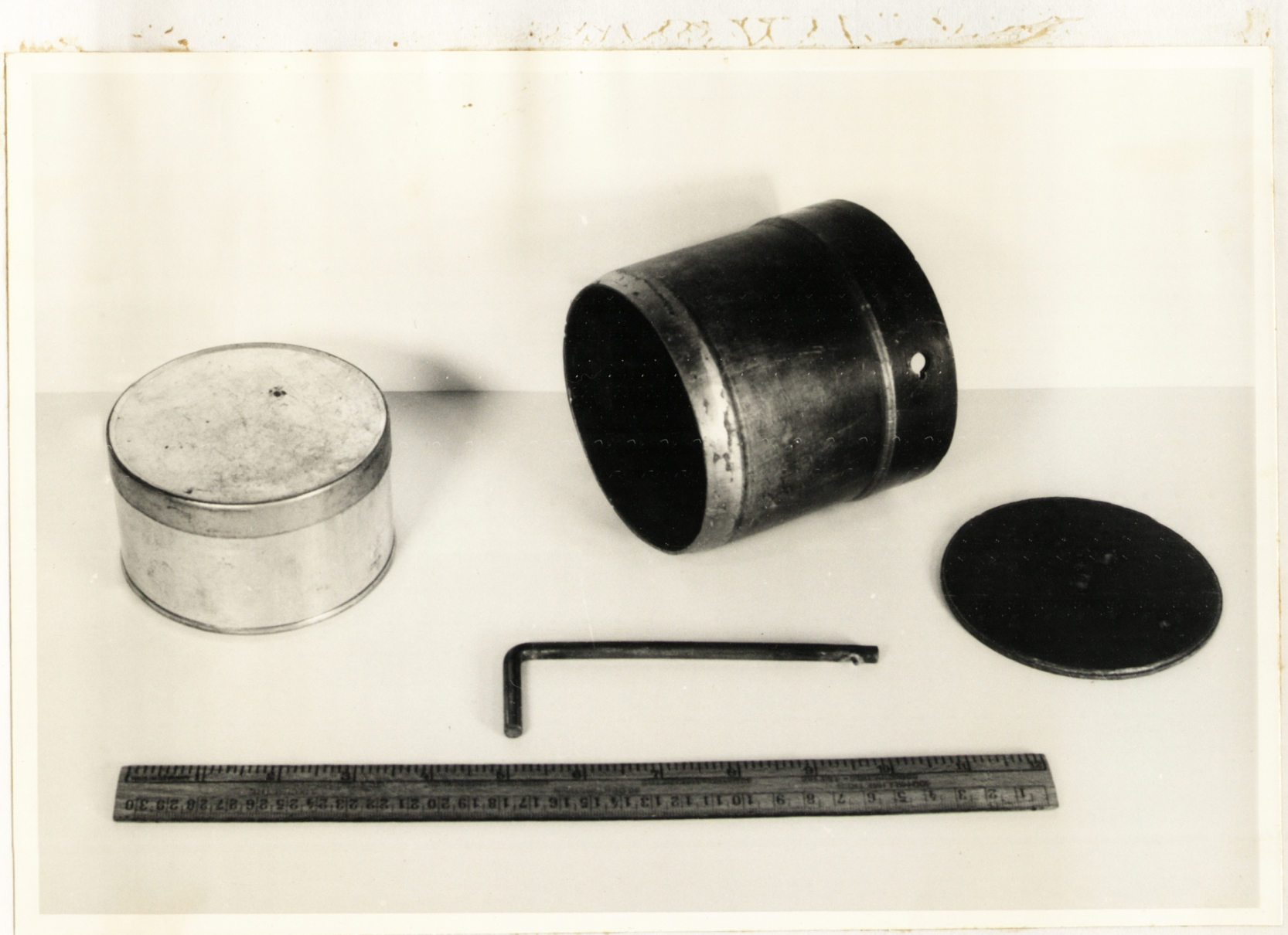

PLATE 3l. "Coile" bulk density sampler. 
Voigt, 1955; Leeper 1957).

Because of the variability in stone content from site to site, the particles greater than $2 \mathrm{~mm}$ in diameter were removed from each of the bulk density samples by sieving. Bulk density of the soil alone was then calculated by subtracting the known weight and calculated volume of stones from the weight and volume of the original sample.

Field capacity (F.C.) determinations were made for the surface two inches of soil (the same depth as the B.D. sample) using a tension plate apparatus. A tension of onethird atmosphere was used because the water held in the soil at this tension is generally considered to be filling only the capillary pore space (Lassen et al. 1952). The soil for these determinations was collected from three places in each plot, bulked and sieved to remove the particles greater than $2 \mathrm{~mm}$ in diameter. Determinations were also made from the subsoil of each site. .

The capillary porosity was calculated from the

formula:

$\begin{aligned} & \text { Capillary } \\ & \text { porosity (\%) }\end{aligned}=\frac{\text { wt. water held in soil at F.C. }}{\text { wt. oven dry soil }}$ $x$ B.D. (soil alone)

Non-capillary porosity (i.e. volume of pores not filled by water at F.C.) was found by subtracting capillary porosity from total porosity.

Mechanical analyses were carried out for each soil horizon at each site using the hydrometer method described by 
Bouyoucos (1936). The results were expressed on the International System.

\section{(ii) Chemical}

Analyses ${ }^{*}$ were carried out on the soil loss from the permanent plots to determine nutrient concentrations. Total nitrogen was determined by the Kjeldahl method; total potassium was determined by using a flame photometer; and total phosphate $\left(\mathrm{P}^{\circ}{ }^{\circ}\right)$ was determined by the molybdenum blue technique.

Samples of run-off water were collected from the artificial rainfalls which followed the prescribed burning experiment at Stromlo Forest; and analysed for calcium, potassium and sodium using a flame photometer.

All chemical analyses were carried out by Dr. C.H, Williams of the Division of Plant Industry, C.S.I.R.0., Canberra, A.C.T. 


\section{CHAPTER 2}

\section{RESULTS}

\section{Results of natural rainfall studies}

The plot data in relation to natural rainfall are summarized in Appendix III.

(a) Relation of surface run-off to amount and type of ground cover

The amount of ground cover was found to be an important factor in controlling surface run-off from all plots at sites A and D. Figure 10 shows the relationships between average surface run-off (for all rains in the study year) and oven dry weight of ground cover for each of the four sites.

Surface run-off remained at low levels at sites $B$ and C, even when the weight of ground cover was low. This was because of the overriding effect of soil factors, which will be discussed in the next section.

The two lines for sites $A$ and $D$ in Figure 10 are almost coincident, yet the plots at site A were covered with leaf litter. while the plots at site $D$ were covered with bracken fern and low shrubs. This suggests that none of the cover types mentioned is more effective than any other in controlling surface run-off. Table 1 shows the average surface run-off (for the year) for selected plots with approximately the same weight of different types of ground cover.

It may be concluded that the amount of ground cover is more important than the type of cover in controlling surface run-off. 


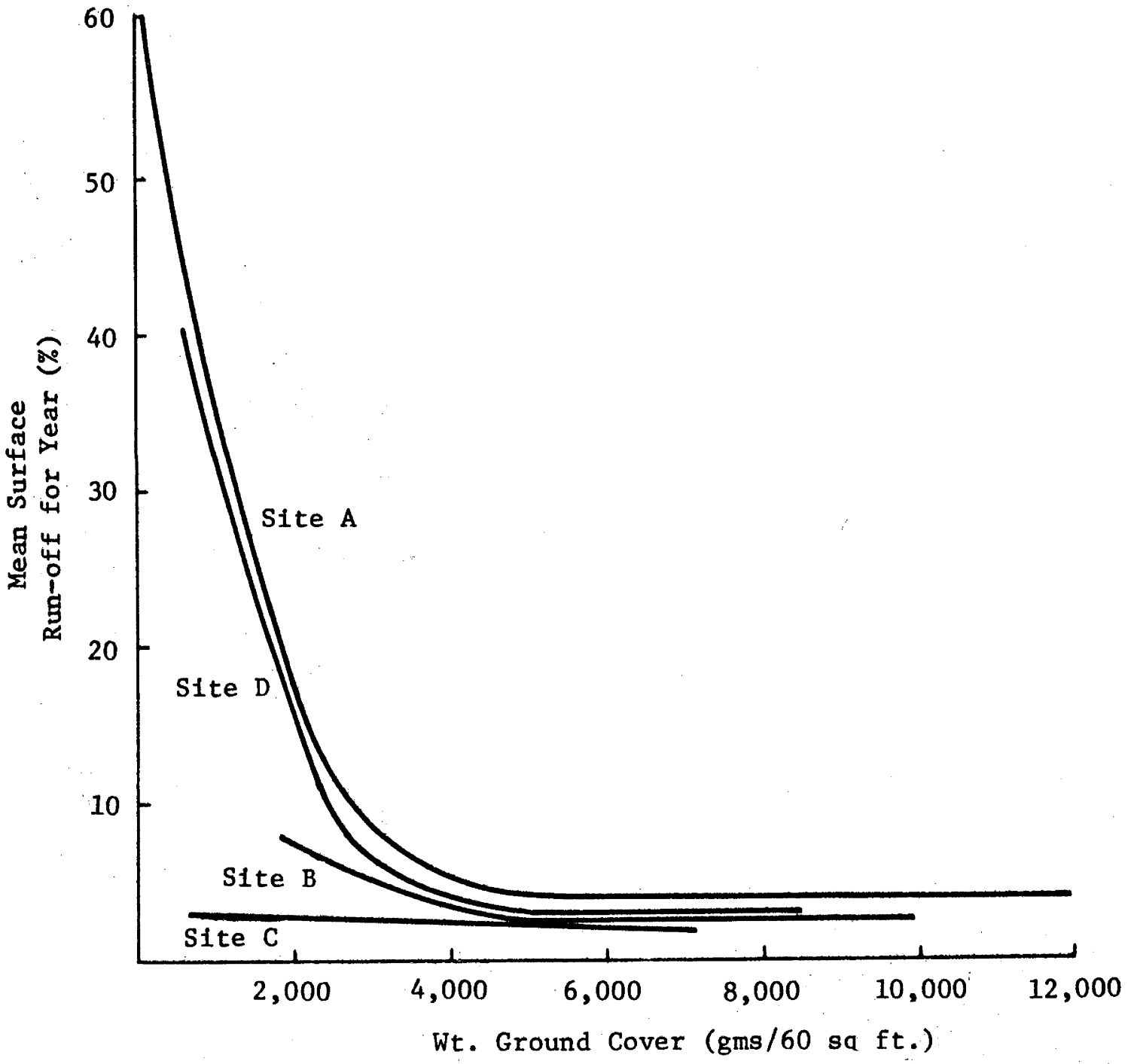

Figure 10. Relation between surface run-off and weight of ground cover for each site. 
Table 1

Effect of different types of ground cover on surface run-off

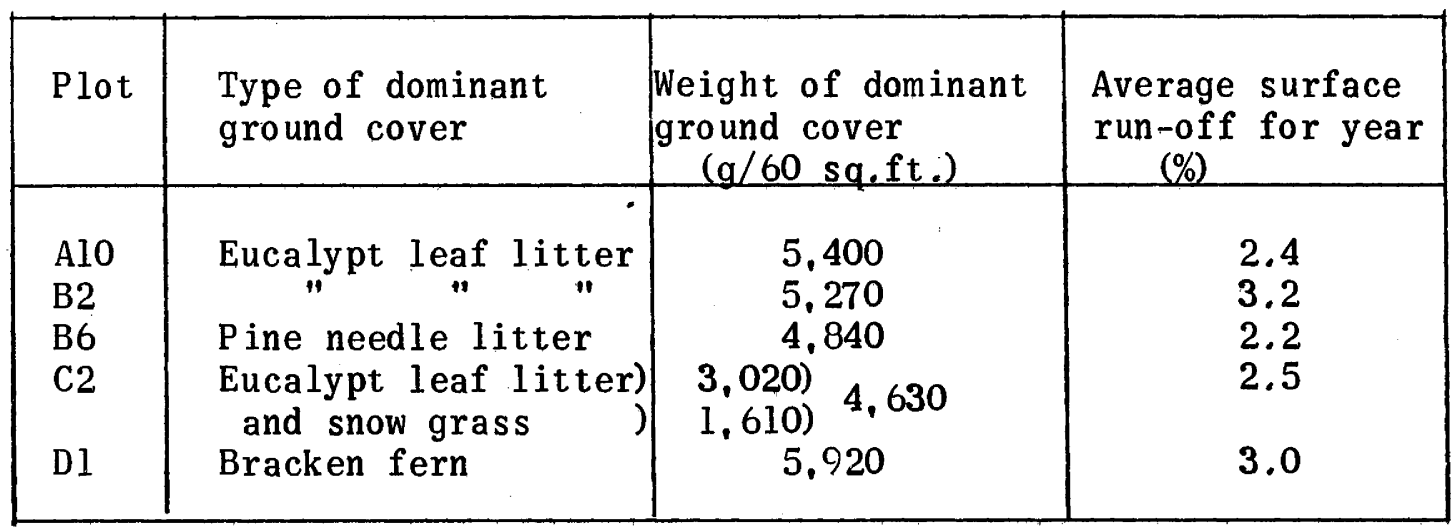

Figure 10 indicates that for sites $A$ and $D$, ground cover at the rate of $4.000 \mathrm{~g} / 60 \mathrm{sq}$. $\mathrm{ft}$. is necessary to keep run-off below the point of inflection.

It was possible to investigate the nature of snow melt run-off at site $D_{\text {; }}$ as about 230 points of precipitation occurred as snow during July and August. Plate 32 shows a light snow cover at site D. No surface run-off occurred from the well vegetated plots for any of the six snow falls encountered. The reaction of the plots.with bare soil exposed depended on whether or not the soil surface was frozen before the snowfall. Table 2 shows the behaviour of two poorly covered plots in relation to frozen and unfrozen soil.

Table 2

Effect of soil freezing on surface run-off from snow melt Site D.

\begin{tabular}{|l|cc|}
\hline Plot & \multicolumn{2}{|c|}{ Surface Run-off (\%) } \\
& Soil Frozen & Soil Unfrozen \\
\hline D8 & 16.1 & 6.0 \\
D9 & 29.1 & 5.8 \\
\hline
\end{tabular}




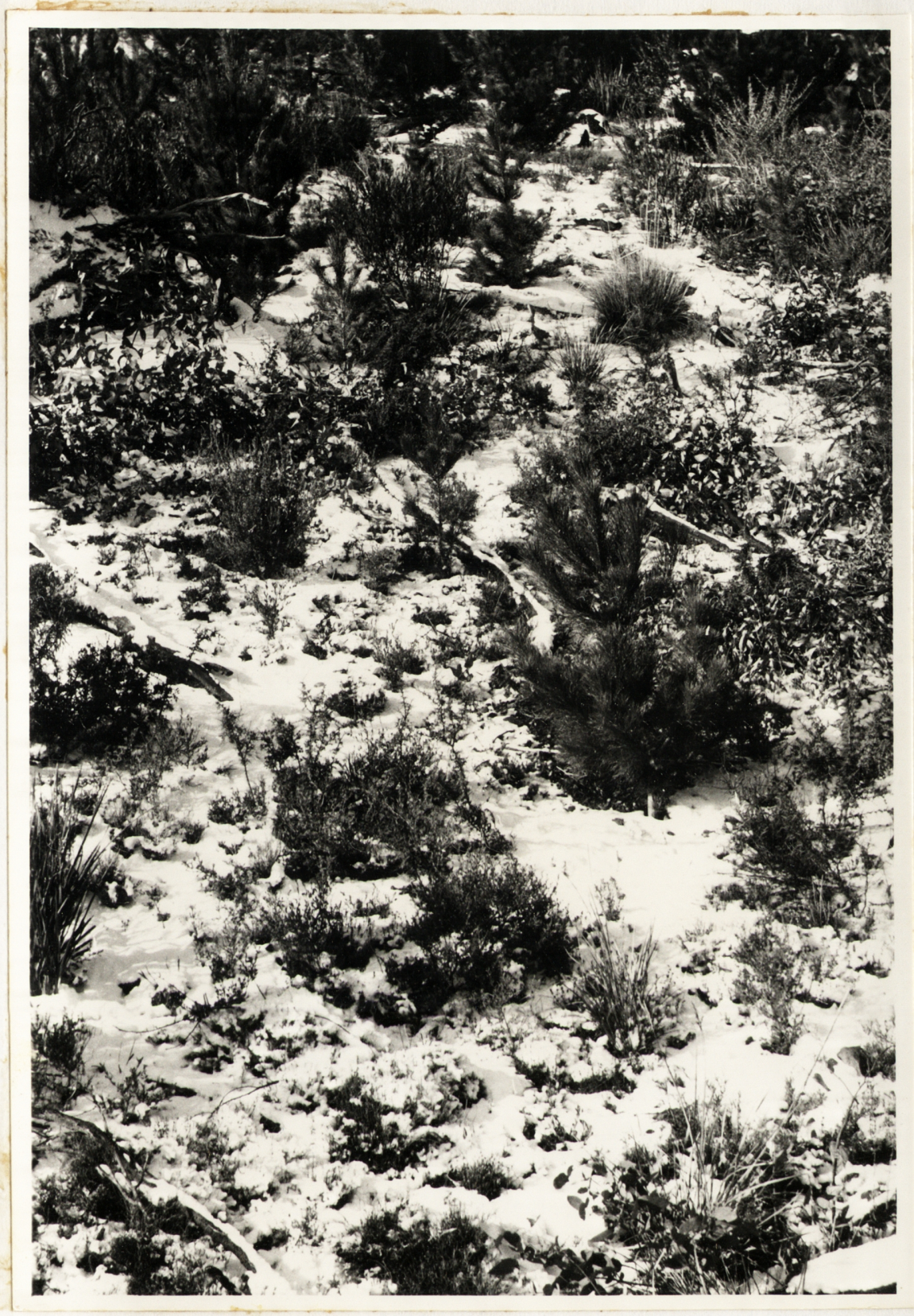

PLATE 32. Light snow cover at site D. 
(b) Relation of surface run-off to soil physical characteristics

Details of the soil physical characteristics determined for each plot and site are given in Appendix IV. As was mentioned earlier (Chapter 1, Section 4(e)), the bulk density of the soil alone (i.e. excluding particles $>2 \mathrm{~mm}$ diameter) was determined because of the variability in stone content between samples. The correlation of average surface run-off (for all rains in the study year) with surface soil bulk density was highly significant (Figure 11). However, when the points for each site were plotted separately, sites A and D showed significant correlations, while for sites $B$ and $C$ there was little change in run-off over a wide range of bulk density values (Figure 12). Although bulk density is correlated with total pore space, it gives no indication of the proportion of large to small pores. Since the number of large pores helps determine the rate of water intake into soil (Lassen et al. 1952), non-capillary porosity is a better parameter to use thán bulk density when several soil types are compared.

The correlation of surface run-off with surface noncapillary porosity for all permanent plots was highly significant (Figure 13). A breakdown of the points into the four sites (Figure 14) revealed that each site fell into one of two patterns: One (sites A and D) where low values of non-capillary porosity were associated with high values of surface run-off; and the other (sites $B$ and C) where low values of non-capillary porosity were associated with low values of surface run-off. The correlations 


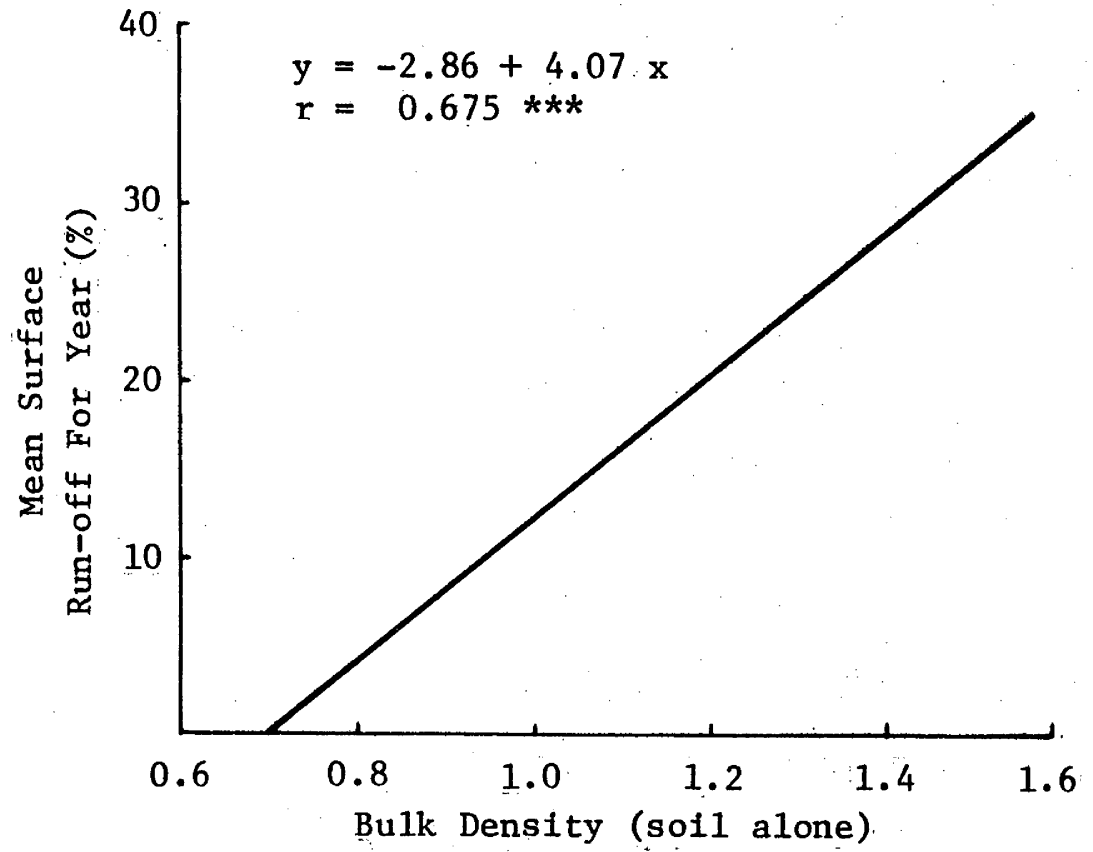

Figure 11. Relation between surface run-off and bulk density for a11 permanent plots.

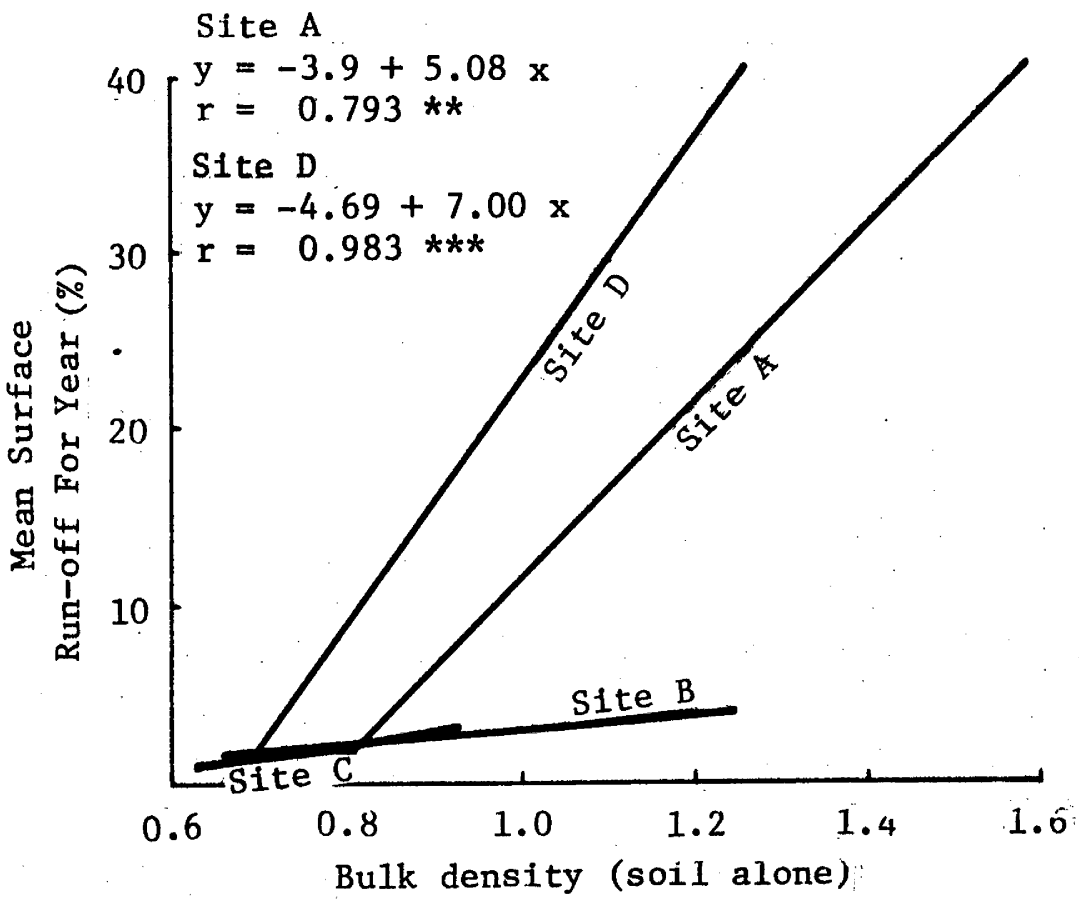

Figure I2. Relation between surface run-off and bulk density for each site. 


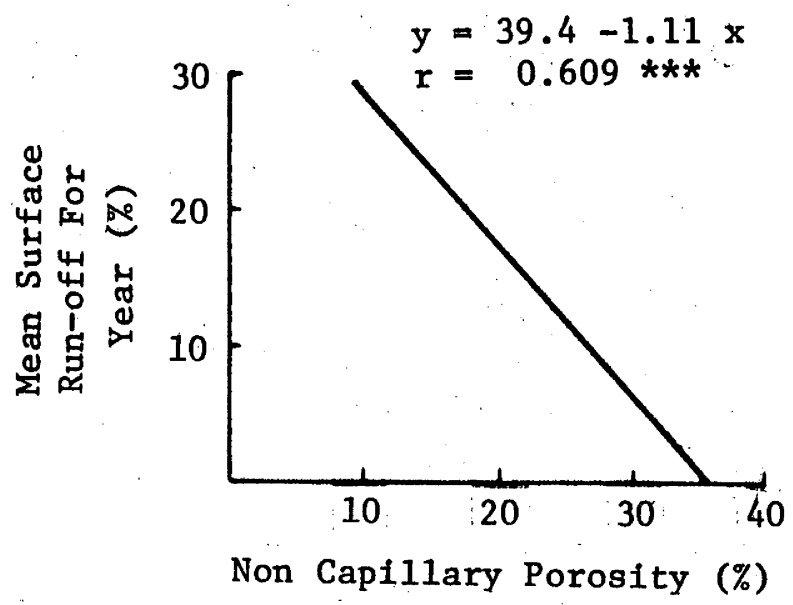

Figure 13. Relation between surface run-off and surface non capillary porosity for all permanent plots.

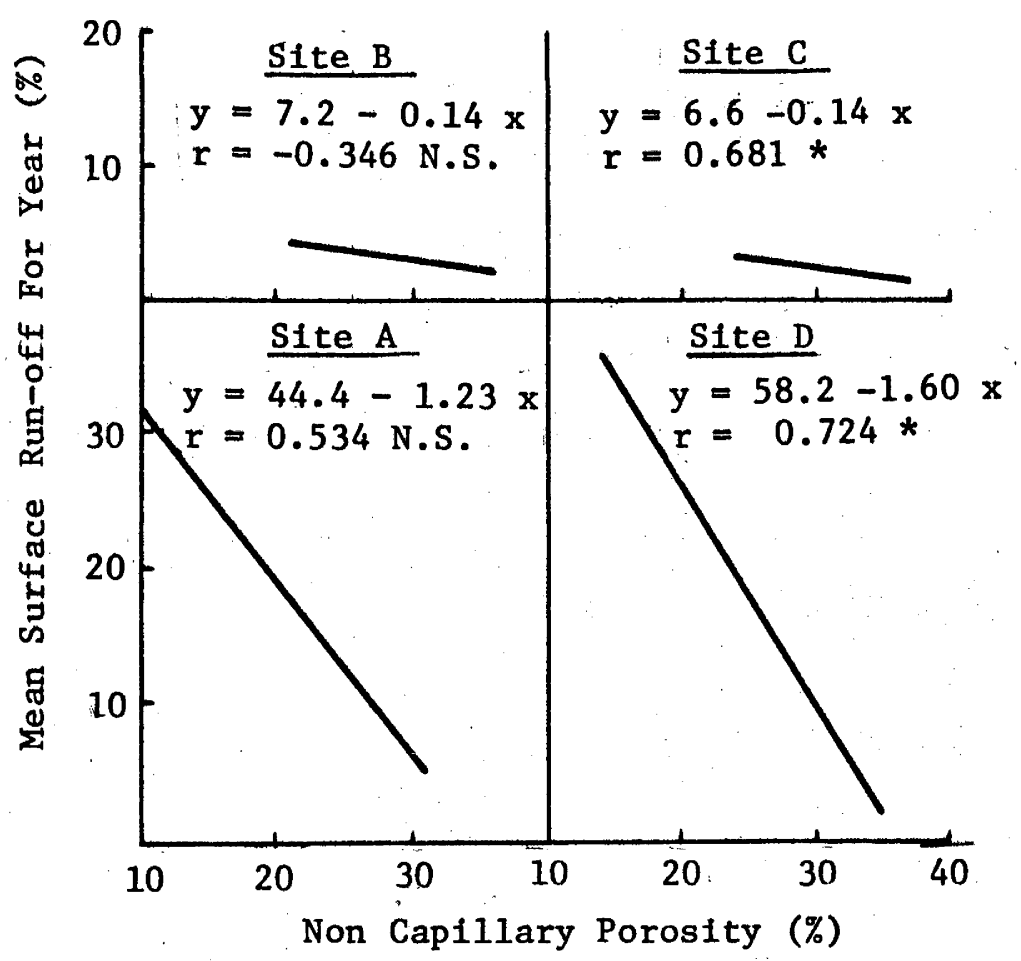

Figure 14. Relation between surface run-off and surface non capillary porosity for each site. 
were significant for sites $C$ and $D$, but within-site variation at sites $A$ and $B$ resulted in non-significant $r$ values.

The difference in behaviour between sites $A$ and $D$ and sites $B$ and $C$ can be explained by a difference in the non-capillary porosity of the subsoil. Table 3 shows subsoil non-capillary porosity values at each site.

Table 3

Subsoil non-capillary porosity at each site.

\begin{tabular}{|l|cccc|}
\hline \multirow{2}{*}{ Depth } & A & Non-capillary porosity (\%) \\
\hline $10-12^{\prime \prime}$ & $10 \pm 1$ & $24 \pm 2$ & $21 \pm 2$ & $12 \pm 2$ \\
\hline
\end{tabular}

It can be seen from Table 3 that there is a segregation into two groups: those with relatively low non-capillary porosity in the subsoil (sites $A$ and $D) ;$ and those with relatively high non-capillary porosity in the subsoil (sites $B$ and $C$ ). The detention storage space (space occupied by the non-capillary pores) is much greater at sites B and $C$ than at sites $A$ and $D$. Hence while the soil at sites $B$ and $C$ can temporarily store a large amount of rainfall, the soil at sites $A$ and $D$ cannot, so the amount that runs off will depend largely on the non-capillary porosity of the surface soil. Thus high run-off occurred at sites $A$ and $D$ when the non-capillary porosity (and detention storage) of the surface soil was low.

Figure 15 shows the importance of non-capillary porosity throughout the profile in limiting detention storage.

The large differences in subsoil non-capillary porosity 
Site A

Low subsoil Non capillary porosity

1. Hi.gh surface non capillary porosity.
2. Low surface non capillary porosity.

Non Capillary Porosity (\%)
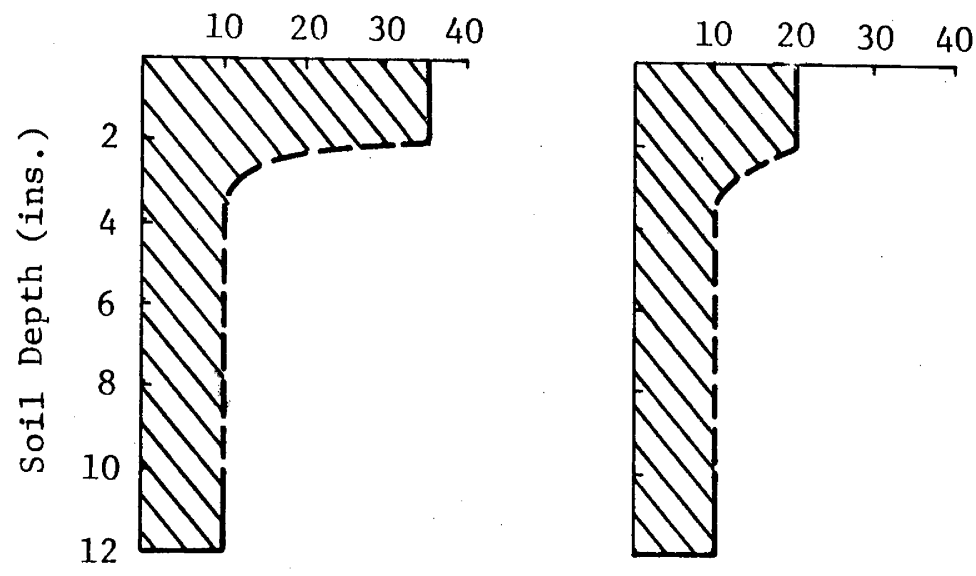

Site C

High subsoil Non Capillary Porosity

3. High surface non capillary porosity.

4. Low surface non capillary porosity.
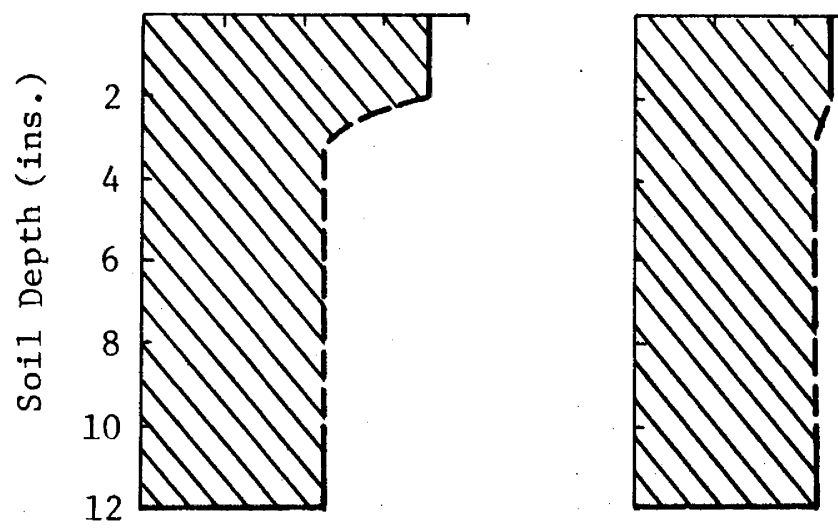

Figure 15. Detention storage of soils with high and low subsoil non capillary porosity.

DV Detention storage. 
shown in Table 3 probably reflect the natural characteristics of the soil parent materials. Soils at sites $B$ and $C$ are derived from coarse grained quartz porphry and acid tuff respectively. These rocks produce coarse grained soils with little profile differentiation. The non-capillary porosity is relatively high and does not differ much between surface and subsoil. In contrast, soils at sites $A$ and $D$ are derived from fine grained metamorphosed sediments and fine grained sediments respectively. The resultant soils are poorly structured and show some degree of profile differentiation and texture contrast. Subsoil non-capillary porosities of these soils are low.

At sites $A$ and D non-capillary porosity in the surface soil was related to the amount of ground cover (Table 4).

\section{Table 4}

As sociation between weight of ground cover and non-capillary porosity - sites $A$ and $D$

\begin{tabular}{|c|c|}
\hline $\begin{array}{c}\text { Ground cover } \\
(\mathrm{g} / 60 \text { sq.ft.) }\end{array}$ & $\begin{array}{c}\text { Non-capillary porosity } \\
(\%)\end{array}$ \\
\hline$>2,000^{*}$ (mean of 16 plots) & $27 \pm 1$ \\
$<2,000$ (mean of 5 plots) & $18 \pm 3$ \\
\hline
\end{tabular}

$\%$

Below the figure of $2.000 \mathrm{~g} / 60 \mathrm{sq}$. ft. bare spaces become obvious and changes in non-capillary porosity associated with changes in ground cover will be marked above and below this value.

No association was apparent between ground cover and surface non-capillary porosity at sites B and C, probably because of the relatively high non-capillary porosity in the subsoil.

To summarize the relationships between surface run-off 
and non-capillary porosity: At sites $B$ and $C$ surface run-off was low at all times because of the relatively high non-capillary porosity throughout the profile. At sites $A$ and $D$, with low noncapillary porosity in the subsoil, surface run-off varied from high to low in accordance with surface non-capillary porosity values - high values being associated with high amounts of ground cover.

(c) Relation of soil loss to amount and type of ground cover and to surface dryness

Figure 16 shows the relationship between total soil loss for the year and weight of ground cover for sites A and D. Soil loss was negligible from plots with more than $4.000 \mathrm{~g} / 60 \mathrm{sq}$. $\mathrm{ft}$. of ground cover: but marked increases in soil loss resulted from cover reductions below this value.

As with surface run-off, the type of ground cover does not seem to be important. The two lines in Figure 16 are almost coincident, yet the plots at site A were covered with leaf litter, while those at site $D$ were covered with bracken fern and low shrubs.

No soil movement occurred during the year's observations at sites $B$ and $C_{\text {, }}$ even on poorly covered plots. This was probably because of the low surface run-off due to the favourable soil conditions of high non-capillary porosity throughout the profile. It was also possible to test the effect of surface dryness on soil loss. From the plots used in the infiltration experiments. 17 were selected which showed some degree of soil loss. The concentration of soil in the run-off water was determined following artificial rainfalls of 80 points in 15 minutes on dry and wet 


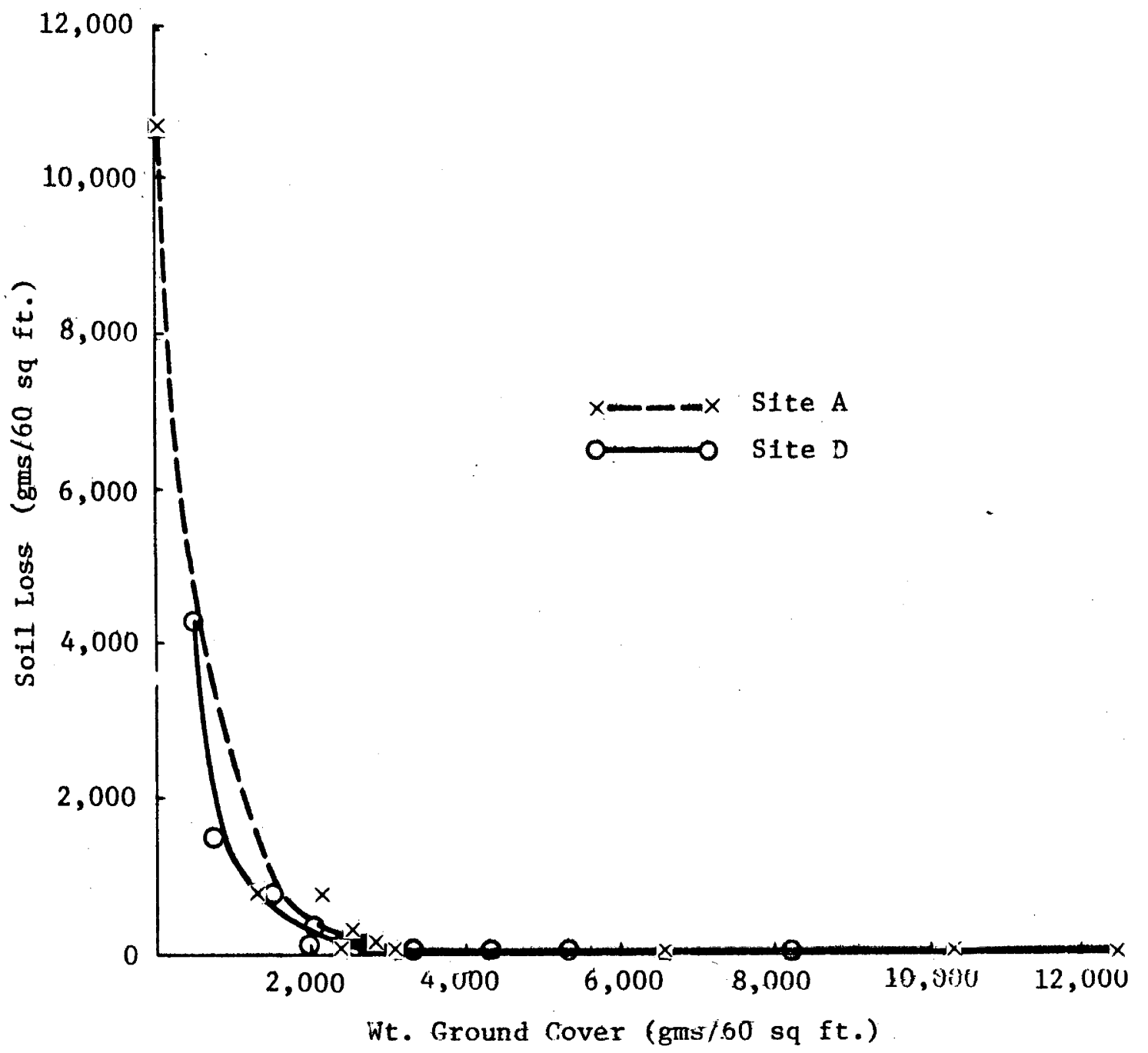

Figure 16. Relation between sol1 loss and welght of ground cover for Sites $A$ and $D$. 
surface soils. The results shown in Table 5 indicate that the soil surface is more erodible when dry than when moist.

Table 5

Effect of surface dryness on soil loss

\begin{tabular}{|c|c|c|}
\hline \multicolumn{2}{|c|}{ Concentration of soil in run-off water (g/litre) } \\
(mean of 17 plots)
\end{tabular}

(d) Relation of nutrient loss to amount of ground cover

The soil loss which was collected from the subsample of run-off water after each natural rainfall was accumulated for each plot, and chemical analyses carried out at the conclusion of the study year. Only 15 plots (eight at site $A$ and seven at site D) provided sufficient soil loss for analyses to be carried out." Detailed results of the analyses are given in Appendix $V_{*}$ and a summary is shown in Table 6.

Table 6

Concentration of nutrients in soil loss from sites $A$ and $D$

\begin{tabular}{|c|c|c|c|}
\hline \multirow{2}{*}{ Site } & \multicolumn{3}{|c|}{ Concentration of nutrients in soil los } \\
\cline { 2 - 4 } & $\begin{array}{c}\text { Total nitrogen } \\
(\%)\end{array}$ & $\begin{array}{c}\text { Total potassium } \\
(\%)\end{array}$ & $\begin{array}{c}\text { Total phos- } \\
\text { phate (ppm) }\end{array}$ \\
\hline $\begin{array}{c}\text { A } \\
\text { (mean of } 8 \text { plots) }\end{array}$ & 0.377 & 2.10 & 1.297 \\
$\begin{array}{c}\text { D } \\
\text { (mean of } 7 \text { plots) }\end{array}$ & 0.376 & 1.52 & 957 \\
\hline
\end{tabular}


The concentration of nitrogen and phosphate was highest in the soil loss from plots with high ground cover (Figures 17 and 18). However, no relationship was apparent between potassium concentration and ground cover. The individual points for sites $A$ and $D$ are shown in Figures 17 and 18 but, since they showed no segregation into sites, only one line was drawn to represent the relationship.

Although the concentration of nutrients was highest in the soil loss from plots with high ground cover the plots with the least amount of cover had the greatest total nutrient loss (Figure 19). This is to be expected because of the inverse soil loss - ground cover relationship shown in Figure 16. Total nutrient losses for each site are given in Appendix V. and a summary is shown in Table 7 .

\section{Table 7}

Weight of nutrient losses for sites $A$ and $D$ during study year

\begin{tabular}{|c|c|c|c|}
\hline \multirow{2}{*}{ Site } & \multicolumn{3}{|c|}{$\begin{array}{c}\text { Weight of nutrients lost during year } \\
(\mathrm{g} / 60 \mathrm{sg} . \mathrm{ft} .)\end{array}$} \\
\hline & Nitrogen & Potassium & Phosphate \\
\hline $\begin{array}{c}\text { A } \\
\text { (mean of } 8 \text { plots) } \\
\text { D } \\
\text { (mean of } 7 \text { plots) }\end{array}$ & 2.977 & 43.11 & 1.350 \\
\hline
\end{tabular}

(e) Influence of rainfall intensity on surface run-off and soil loss; and importance of infrequent heavy rains

$$
\text { Rainfall intensities in excess of the infiltration rate }
$$

will produce surface run-off (Horton 1933). The amount of run-off produced will depend on the intensity and duration of the rainfall. 


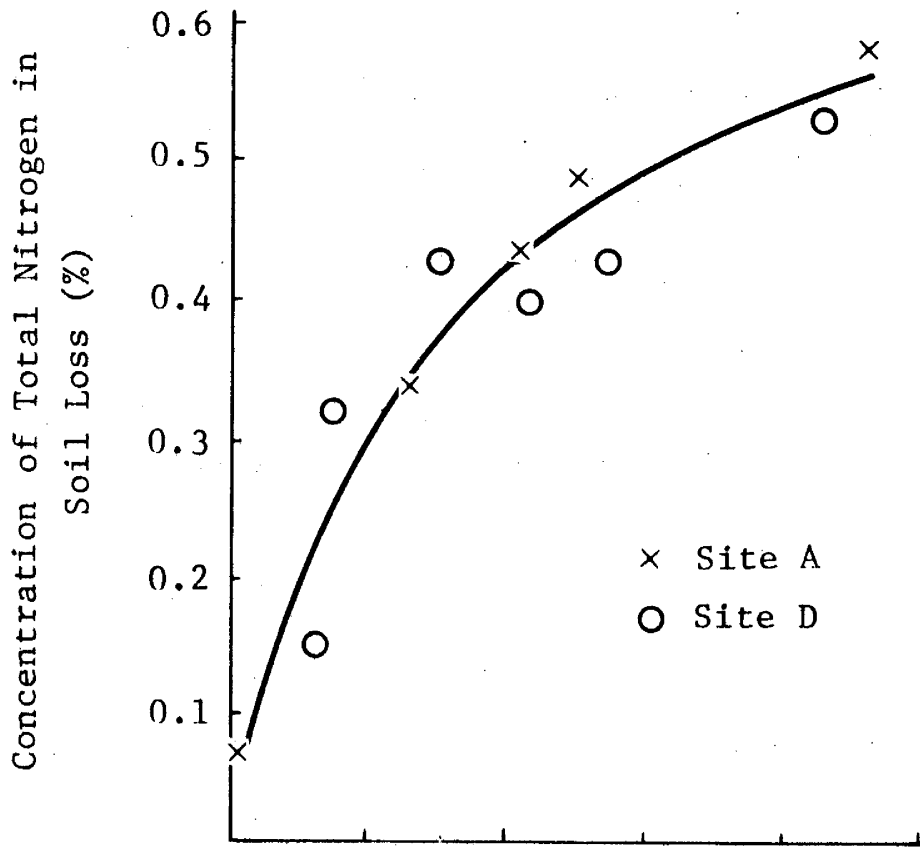

Figure 17. Influence of ground cover on nitrogen content of soil loss.

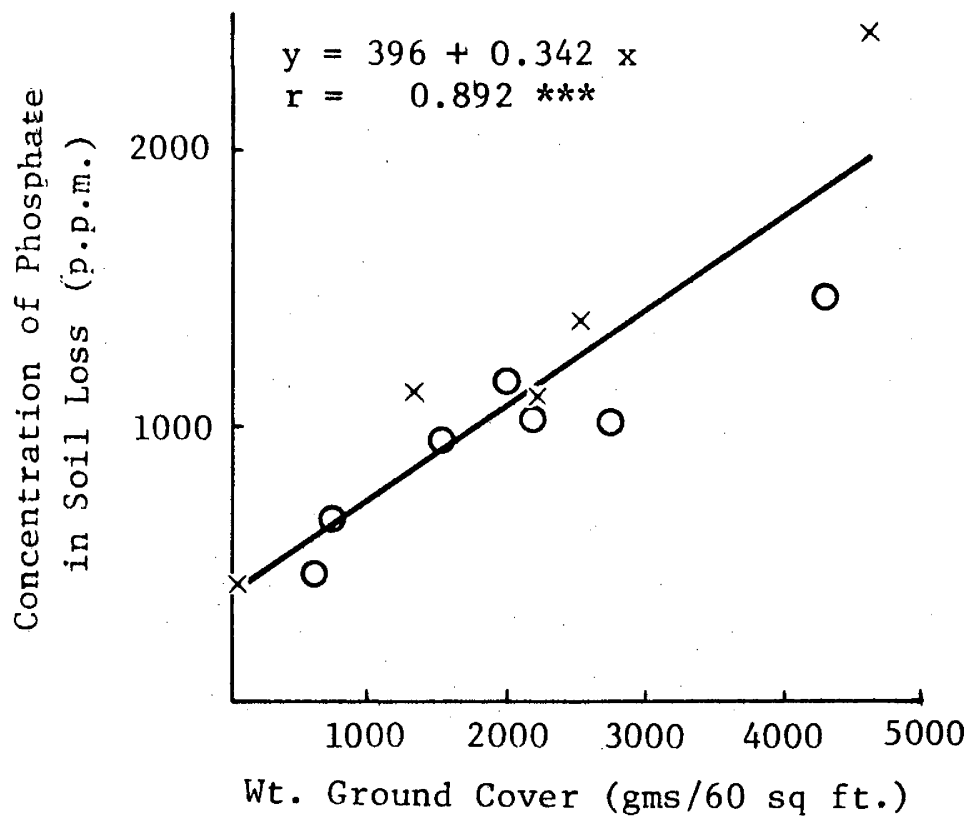

Figure 18. Influence of ground cover on phosphate content of soil loss. 

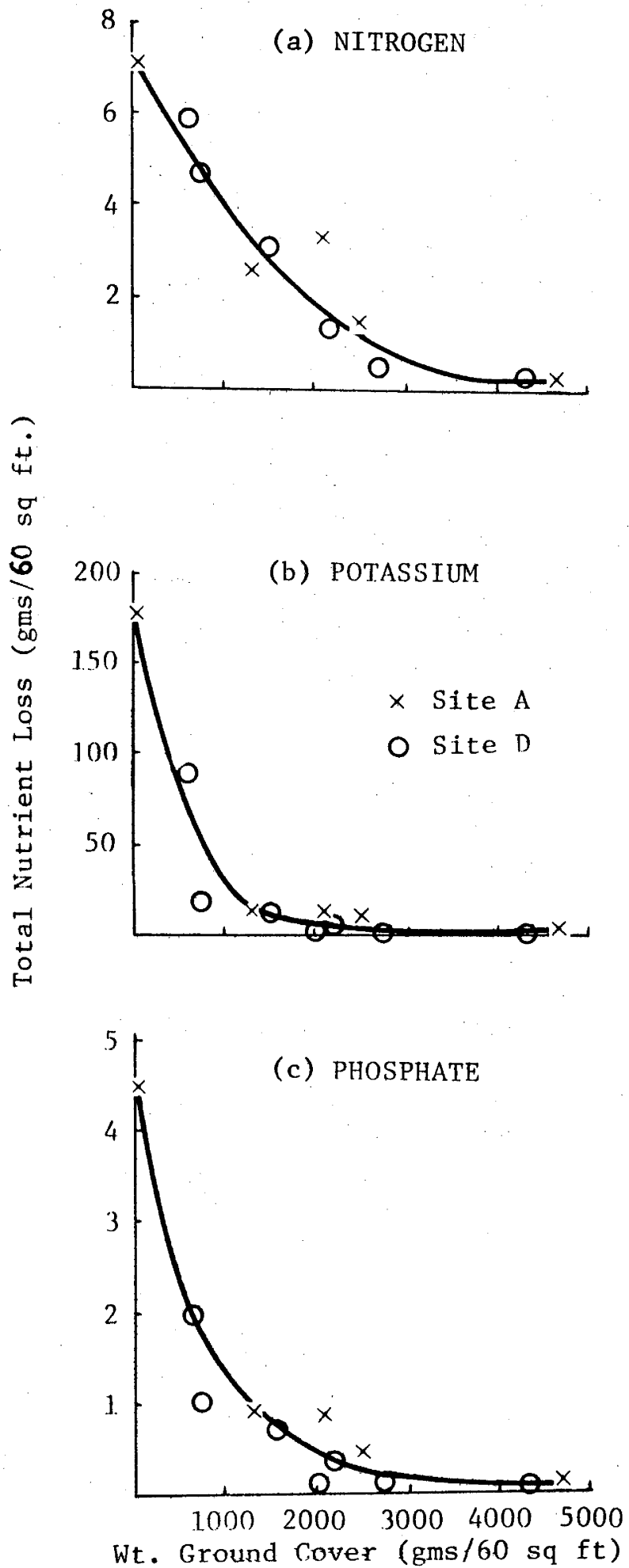

Figure 19. Relation between total nutrient loss and ground cover 
Figure 20 shows the situation for a high and a low intensity rainfall at site $D$.

A similar relationship exists between soil loss and rainfall intensity (Figure 21 ) .

With factors other than rainfall held constant, soil loss increased with the rainfall intensity (Figure 22). Up to about $1.5 \mathrm{in} / \mathrm{hr}$. (maximum 10 minute intensity) soil loss showed only a moderate increase, but increases in intensity beyond this figure resulted in large increases in soil loss.

For firebreak plot fill the three most intense rainstorms produced more soil loss than the remaining 72 rainfalls which occurred during the study year (Table 8).

Table 8

Importance of intense rainfall in producing soil loss (Plot All).

\begin{tabular}{|c|c|c|c|c|c|}
\hline & \multicolumn{3}{|c|}{ Rainfall } & \multicolumn{2}{|c|}{ Soil loss } \\
\hline & $\begin{array}{l}\text { No of } \\
\text { fails }\end{array}$ & Inches & $\begin{array}{l}\text { \% of total } \\
\text { rainfall }\end{array}$ & $\begin{array}{l}\text { Weight } \\
\text { (g) }\end{array}$ & $\begin{array}{l}\% \text { of total } \\
\text { soil loss }\end{array}$ \\
\hline Total for year & 75 & 42.39 & 100 & 10.716 & 100 \\
\hline $\begin{array}{l}\text { Result of } \\
\text { Intense Falls } \\
(>60 \mathrm{pts} / \mathrm{hr})\end{array}$ & 13 & 14.11 & 33 & 9,406 & 88 \\
\hline $\begin{array}{l}\text { Result of very } \\
\text { Intense Falls } \\
(>200 \mathrm{pts} / \mathrm{hr})\end{array}$ & 3 & 7.56 & 18 & 6,686 & 62 \\
\hline
\end{tabular}

$*$

Intensities are the maximum attained during a 10 minute period.

In these studies, the storm duration and total amount of rain appeared to be less important than intensity in determining soil loss (Table 9). 


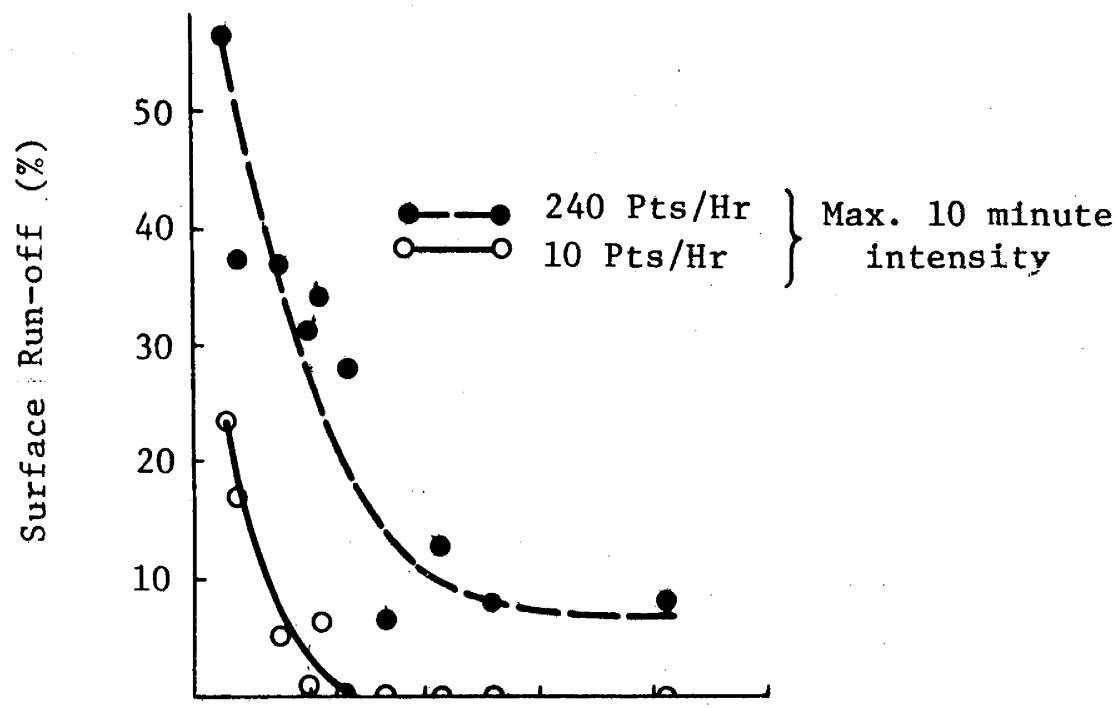

Figure 20. Effect of rainfall intensity on surface run-off - Site D.

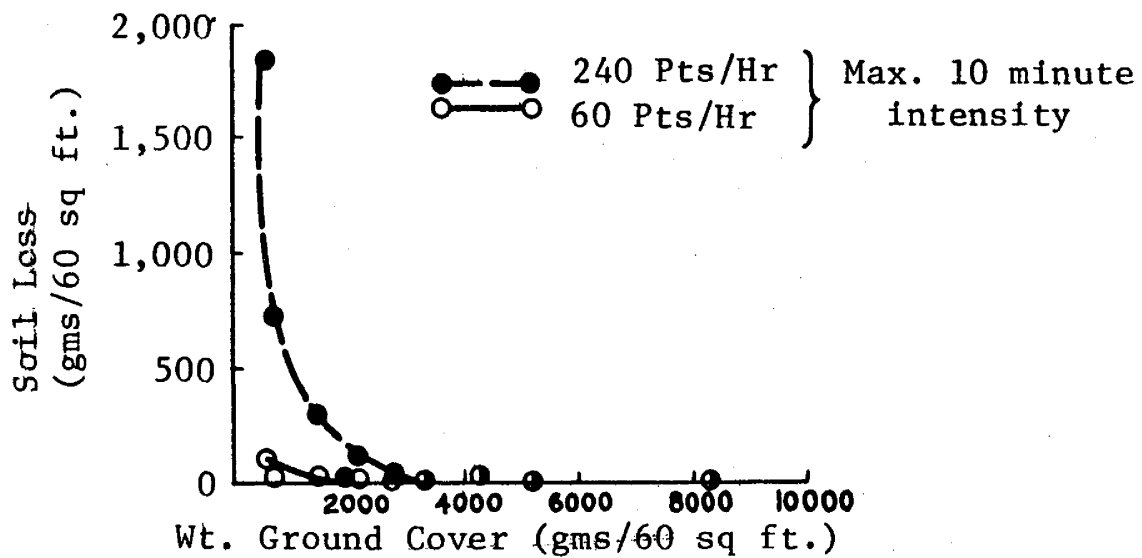

Figure 21. Effect of rainfall intensity on soil loss - Site D.

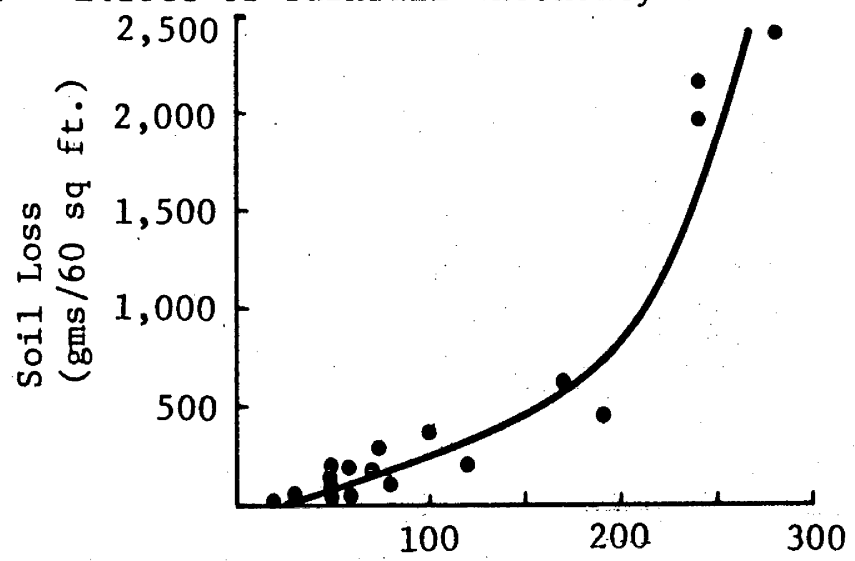

Rainfall Intensity (Pts/Hr) - Max. 10 minute intensity

Figure 22. Relation between soil loss and rainfall intensity - P1ot A11. 
Table 9

Effect of duration, amount and intensity of rainfall on soil loss (Plot All)

\begin{tabular}{|l|l|l|c|c|}
\hline Date of fall & Inches & Duration & $\begin{array}{c}\text { Maximum 10 min. } \\
\text { intensity } \\
\text { (in./hr) }\end{array}$ & $\begin{array}{c}\text { Soil los s } \\
(\mathrm{g})\end{array}$ \\
\hline 31.10 .63 & 0.64 & $15 \mathrm{~min}$ & 2.80 & 2.456 \\
31.1 .64 & 1.63 & $2 \mathrm{hr} 45 \mathrm{~min}$. & 2.40 & 2.015 \\
6.3 .64 & 5.29 & $7 \mathrm{hr} 15 \mathrm{~min}$. & 2.40 & 2.215 \\
\hline
\end{tabular}

The soil surface before each storm was moist from previous rains, so no differential effect of surface dryness was present. The three storms maintained approximately the same intensity throughout their entire duration. It seems reasonable to deduce that most of the soil loss occurred in the first few minutes of rain, since the soil loss from each fall was approximately the same.

\section{Results of infiltration studies}

Infiltration runs were carried out on all the 41 permanent plots and on 33 roving plots in an attempt to clarify further the factors affecting infiltration. In most cases two runs were carried out, a dry run and a wet run (see Chapter 1. Section 4 (e) for details of the methods used).

(a) Relation of infiltration to amount and type of ground cover When data from all the plots were combined, a highly significant correlation was obtained between the constant infiltration rate (fc.) from the wet run and the oven dry weight of ground cover (Figure 23). Twelve of the plots did not produce any surface run-off from the artificial rainfall, so it was concluded that the 


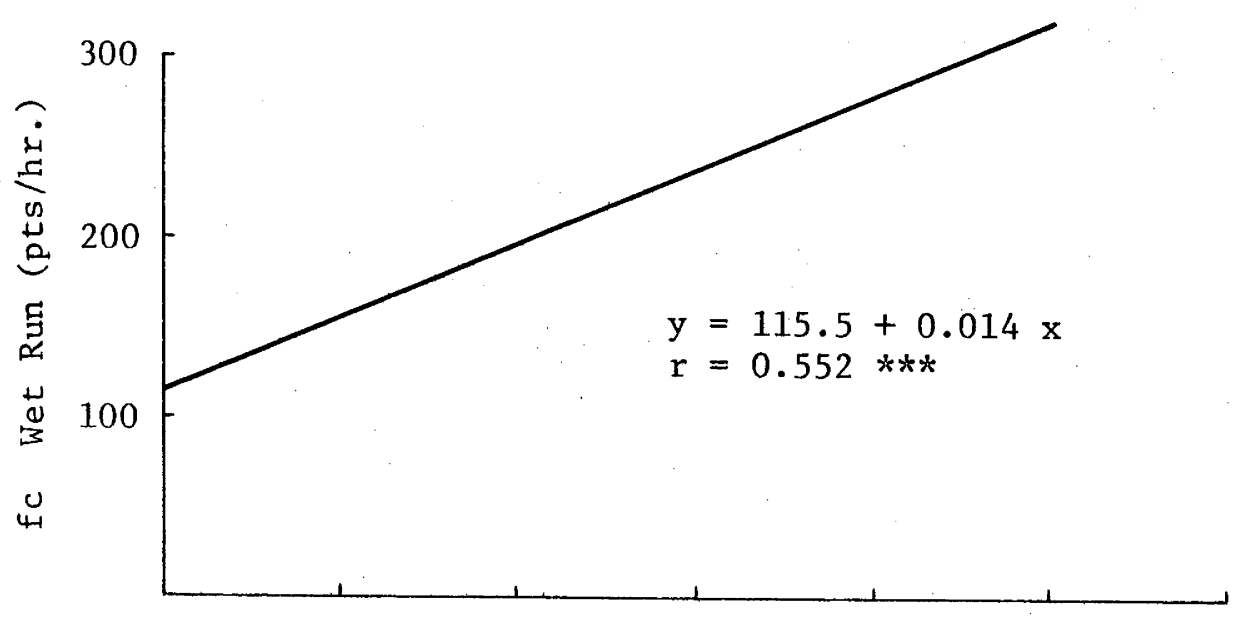

Figure 23. Relation between infiltration and ground cover for all plots.

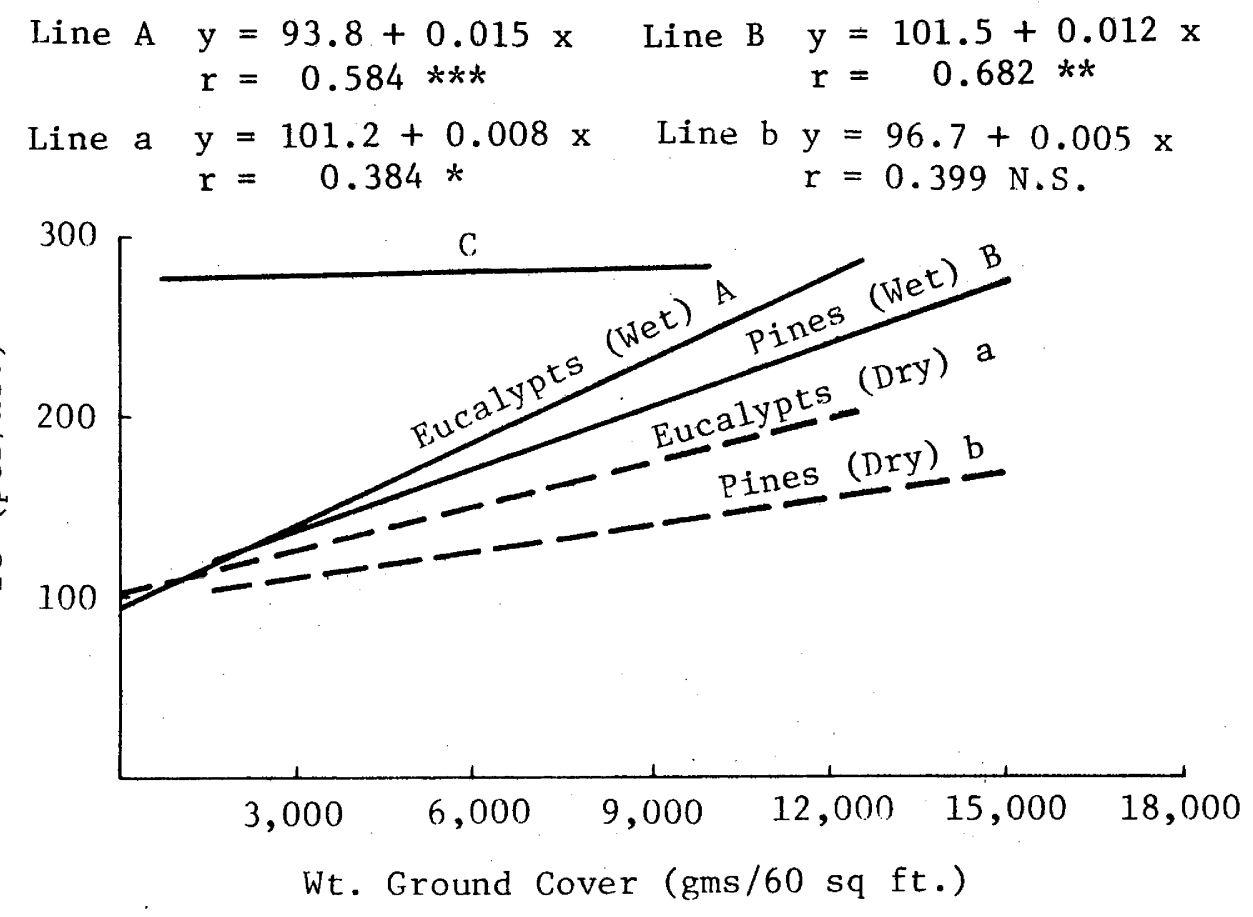

Figure 24. Relation between infiltration and ground cover for different cover types. 
infiltration rate was in excess of the rate of applied rainfall (320 pts/hr) 。 Data from these plots were not included in Figure 23. Appendix VI contains all the relevant plot data from which this figure was derived.

Data from all plots at site $\mathrm{C}$ and from the eucalypt plots at site B were excluded from the remainder and a separate relationship determined. This relationship is shown as line $\mathrm{C}$ in Figure 24. These plots were excluded because of the importance of soil factors rather than ground cover in determining infiltration (see Section 1(b) of this chapter for details). As may be seen from line $C$, the constant infiltration rate is approximately unchanged over a wide range of ground cover.

The rest of the plots were divided into two groups:

(i) Those dominated by pine litter.

(ii) The remainder, most of which were dominated by eucalypt litter, but including several almost bare plots from firebreaks and several which were dominated by low shrubs .

Correlations were determined between constant infiltration rate and amount of ground cover (for each of these two groups) for both dry and wet runs (Figure 24)。. The wet run values for eucalupts and pines (lines $A$ and $B$ respectively) were of the same order, particularly for the low to medium amounts of ground cover. The possible implications of the differential effect of high amounts of pine and eucalypt ground cover on infiltration are discussed in the following chapter. 
An interesting feature of Figure 24 is that infiltration is lower during the dry run than during the wet run for both cover types, and the difference in infiltration (between the dry and wet runs) increases with increasing amounts of ground cover. This behaviour is contrary to what is normally expected from a purely physical interpretation of the infiltration process. It suggests the operation of some hydrophobic agent associated with the ground cover. There are two possible explanations:

(i) The water is repelled by the litter itself.

(ii) The water is repelled by the finely divided organic matter and the associated fungal and microbial products at the soil-litter interface.

In areas with very little ground cover (the lower end of lines $A$ and a in Figure 24) the usual trend is seen to occur, viz. the infiltration rate decreases with increasing moisture content of the profile. This lends weight to the suggestion that the resistance to wetting is associated with the ground cover and is not a characteristic of the soil itself.

The practical implications of this hydrophobic effect are discussed in the following chapter.

Further tests were carried out on the effect of cover on infiltration. The ground cover was harvested and removed from several eucalypt plots following the wet run; and another infiltration run carried out on the moistened soil (bare run). The results are shown in Figure 25. The infiltration values for the bare run were plotted against the amount of ground cover that was present before removal. There was an overall reduction in infiltration following 


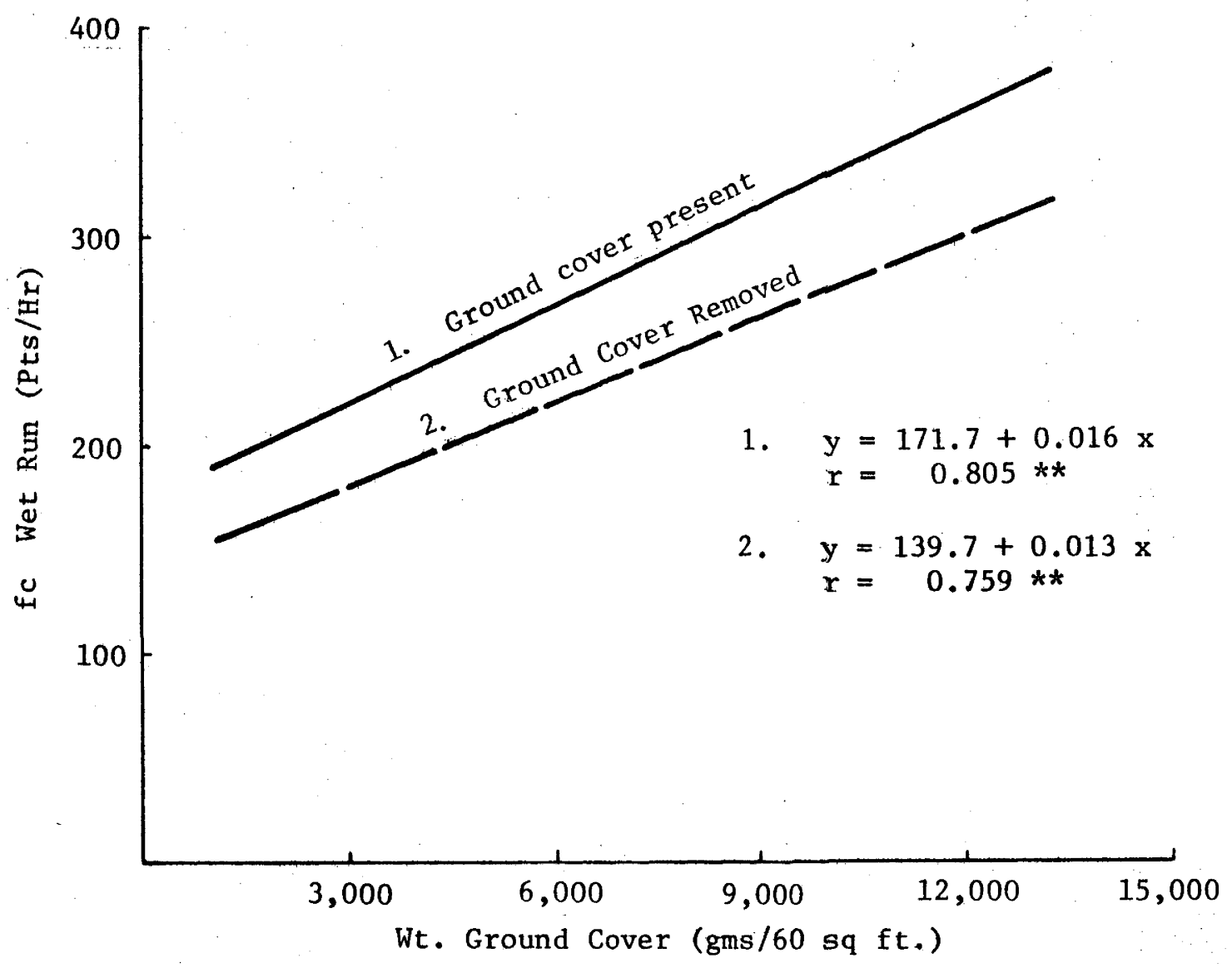

Figure 25. Effect of removing ground cover on infiltration. 
the removal of the cover; but the highest infiltration rates still occurred on the plots that had the greatest amount of cover. This indicates that cover has some effect on soil properties and does not just act as a mechanical barrier to the flow of surface run-off. However, the reduction in infiltration after harvesting was probably partly due to this mechanical effect.

(b) Relation of infiltration to soil physical characteristics Since the amount of infiltration determines the amount of surface run-off, the same considerations apply to this section as to the section on the relation of surface run-off to soil physical characteristics (Section $1(b)$ of this chapter).

A similar relationship was obtained between constant infiltration rate and surface non-capillary porosity (Figure 26) as was obtained between surface run-off and surface non-capillary porosity (Figure 13). However, a breakdown of the points into the individual sites failed to show any significant correlation for any of the four sites.

\section{Hydrological effects of management practices}

(a) Effect of prescribed burning in a pine plantation on infiltration and nutrient loss

Details of the plot layout are given in Chapter 1. Section 4(c). To summarize: eight plots were installed and two infiltration runs carried out - a dry run and a wet run. An area including four of the plots was burnt and two more infiltration runs were carried out.

Physical characteristics of the fire and detailed plot 


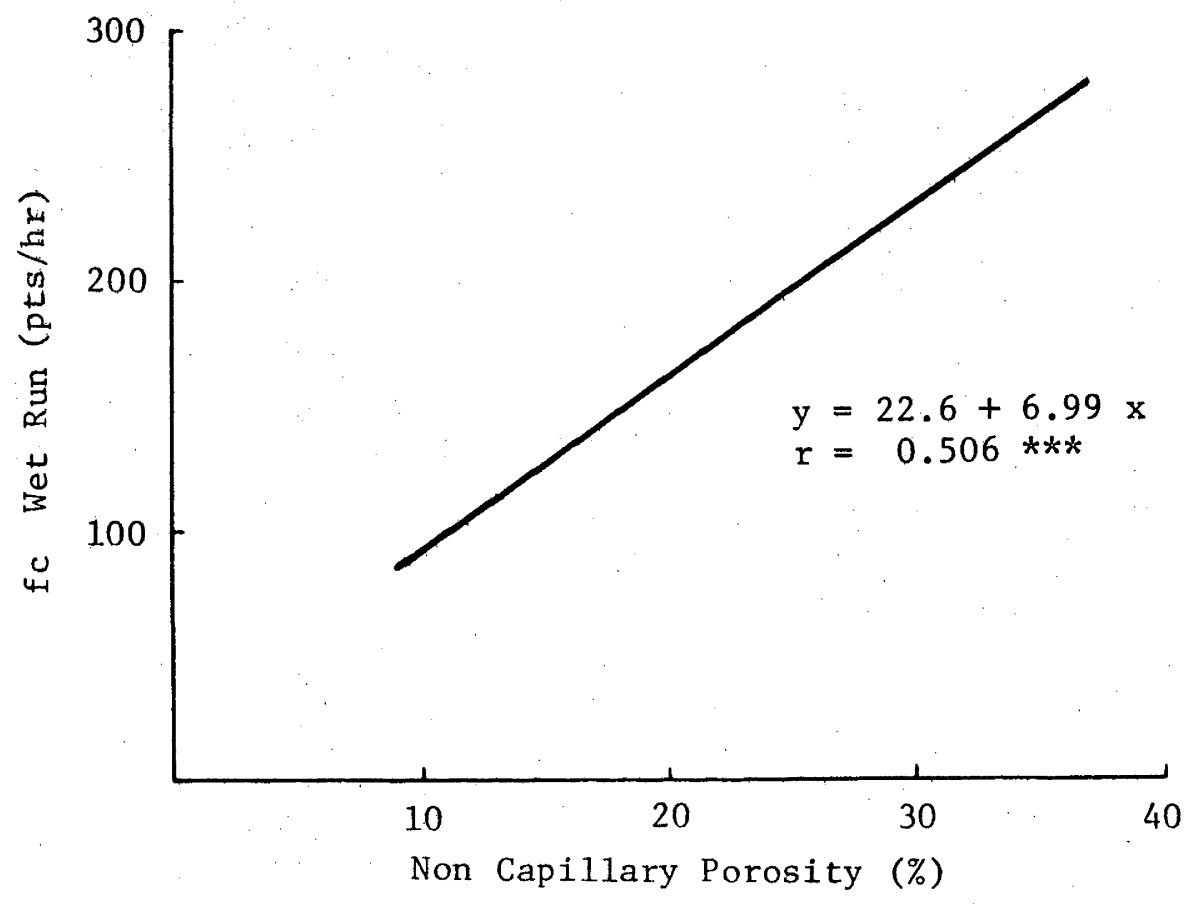

Figure 26. Relation between infiltration and surface non capillary porosity. 
data are given in Appendix VII, and a summary of the results is shown in Table 10 .

Table 10

Effect of prescribed burning on infiltration rates - Stromlo Forest

\begin{tabular}{|l|c|c|}
\cline { 2 - 3 } & \multicolumn{2}{|c|}{ Infiltration Rate (pts/hr) } \\
\cline { 2 - 3 } & Pre Burn Wet Run & Post Burn Wet Run \\
\hline $\begin{array}{l}\text { Control - Unburnt } \\
\text { (mean of } 4 \text { plots) }\end{array}$ & $159 \pm 20$ & $150 \pm 19$ \\
$\begin{array}{l}\text { Treated - Burnt } \\
\text { (mean of } 4 \text { plots) }\end{array}$ & $187 \pm 22$ & $164 \pm 26$ \\
\hline
\end{tabular}

The infiltration rates shown in Table 10 are for the pre- and postburn wet runs. These are the runs which are most comparable because the soil was moistened by the dry run the previous day, so all plots had a similar soil moistưre content before the wet run was carried out.

The control plots showed a slight but non-significant reduction in infiltration. The treated plots showed a somewhat greater reduction in infiltration. but the difference was still not significant.

When the ground cover was investigated it was found that only about $26 \%$ of the fine fuel had been consumed by the fire. Bare soil was exposed only in a few small isolated spots beneath heavy slash piles, and the layer of duff on the soil surface was largely undisturbed by the fire and was still quite moist after the fire had passed. The average weight of ground cover (excluding heavy fuel) was reduced from an estimated $4.970 \mathrm{~g} / \mathrm{plot}$ before the fire to $3,690 \mathrm{~g} / \mathrm{plot}$ after the fire. This residual cover which consisted 
mainly of pine litter, was sufficient to maintain high infiltration rates. In terms of tons per acre, the reduction in fine fuel was from 3.6 to 2.6 tons per acre, which was considered to be satisfactory in terms of hazard reduction.

No actual soil was lost from any of the plots either before or after the fire, but the run-off water from the burnt plots was noticeably discoloured, so subsamples were taken and the water analysed. The water was free of ash in solid form, probably because the residue of ground cover filtered out any ash from the run-off water.

The results of the chemical analyses are shown in Table 11.

Table 11

Concentration of nutrients in the run-off water from an artificial rainfall of 80 points in 15 minutes for burnt and unburnt plots

\begin{tabular}{|l|c|c|c|}
\hline \multirow{2}{*}{ Nutrient } & Control (Unburnt) & \multicolumn{2}{|c|}{ Treated (Burnt) } \\
\cline { 2 - 4 } & Wet Run & Dry Run & Wet Run \\
\hline Calcium (ppm) & 0 & $6.4 \pm 0.9$ & $0.8 \pm 0.3$ \\
Potassium (ppm) & $2.4 \pm 0.2$ & $10.1 \pm 0.4$ & $4.6 \pm 0.1$ \\
Sodium (ppm) & $3.32 \pm 0.13$ & $4.21 \pm 0.23$ & $3.57 \pm 0.10$ \\
\hline
\end{tabular}

The burning produced significant increases in the concentration of all three nutrients in the run-off water from the dry run. However, increases in the concentration of nutrients in the run-off water from the wet run were only significant for calcium and potassium. The concentration of sodium had returned almost to the level of the control. The concentration of all three nutrients 
showed significant decreases from the dry run to the wet run.

It was not possible to carry out phosphate determinations on individual samples of the run-off water because of the small quantity of the samples. However, subsamples of the run-off water from all treated plots were bulked and oven dried, and a phosphate determination carried out on the solid residue. The average concentration of phosphate for both dry and wet runs when expressed on the same basis as the figures in Table 11 (i.e. concentration in the run-off water) was found ta be 13.00 p.p.m.

(b) Effect of revegetating a firebreak on infiltration and soil loss

Details of the methods used for revegetation, and the plot layout are given in Chapter 1. Section 4(d). In brief: clover was established (with the use of fertilizers) on a steep section of a firebreak in Pierce's Creek Forest. Eight plots were installed (four on a planted section and four on an unplanted section) and two infiltration runs carried out (a dry and a wet run). Detailed results are given in Appendix VI (Plots R34 - R41), and summaries are shown in Tables 12 and 13.

Table 12

Constant infiltration rate of planted and unplanted sections of a firebreak for both dry and wet runs (each value is the mean of four plots).

\begin{tabular}{|c|c|c|c|}
\hline \multicolumn{2}{|c|}{ Dry Run Infiltration Rate (pts/hr) } & Wet Run Infiltration Rate (pts/hr) \\
\hline Planted & Unplanted & Planted & Unplanted \\
\hline $122 \pm 28$ & $93 \pm 15$ & $120 \pm 33$ & $60 \pm 19$ \\
\hline
\end{tabular}


Table 13

Soil loss from planted and unplanted sections of a firebreak from an artificial rainfall of 80 points in 15 minutes (each value is the mean of four plots)

\begin{tabular}{|c|c|c|c|}
\hline \multicolumn{2}{|c|}{ Dry Run Soil Loss (g/60 sq.ft.) } & Wet Run Soil Loss (g/60 sq.ft) \\
\hline Planted & Unplanted & Planted & Unplanted \\
\hline $72 \pm 59$ & $190 \pm 134$ & $75 \pm 60$ & $169 \pm 107$ \\
\hline
\end{tabular}

None of the differences (between planted and unplanted areas) in either infiltration or soil loss were significant. However, one of the planted plots had very little clover growing on it conly $24 \%$ cover) and infiltration remained low (36 pts/hr for the wet run) and soil loss was high (255 $\mathrm{g}$ for the wet run).

In spite of the non-significance of the differences, the trend of decreasing soil and water losses with increasing vegetative cover was obvious (Figures 27 and 28).

It is felt that soil and water losses were decreased by the planting of clover, and that the position will improve as the clover becomes better established.

4. Condition of und isturbed eucalypt forest and pine plantations derived from it

Pines and eucalypts were compared at each of the four permanent plot sites using all the physical characteristics measured. Comparisons were made by using $t$ tests, and an I.B.M. 1620 digital computer was used to carry out the calculations. Detailed results are given in Appendix VIII.

Most of the differences between pines and eucalypts were 


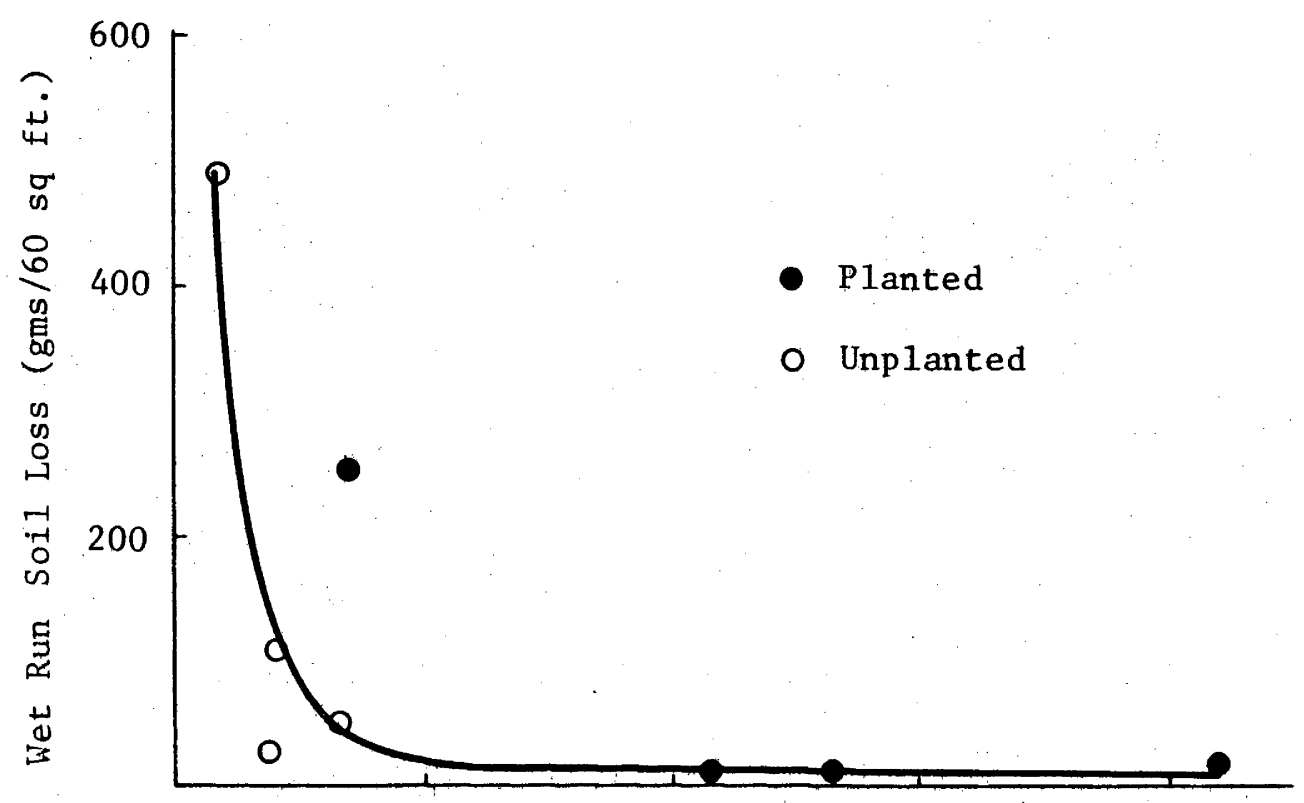

Figure 27. Relation between soil loss and ground cover (for an artificial rainfall of 80 points in 15 minutes).

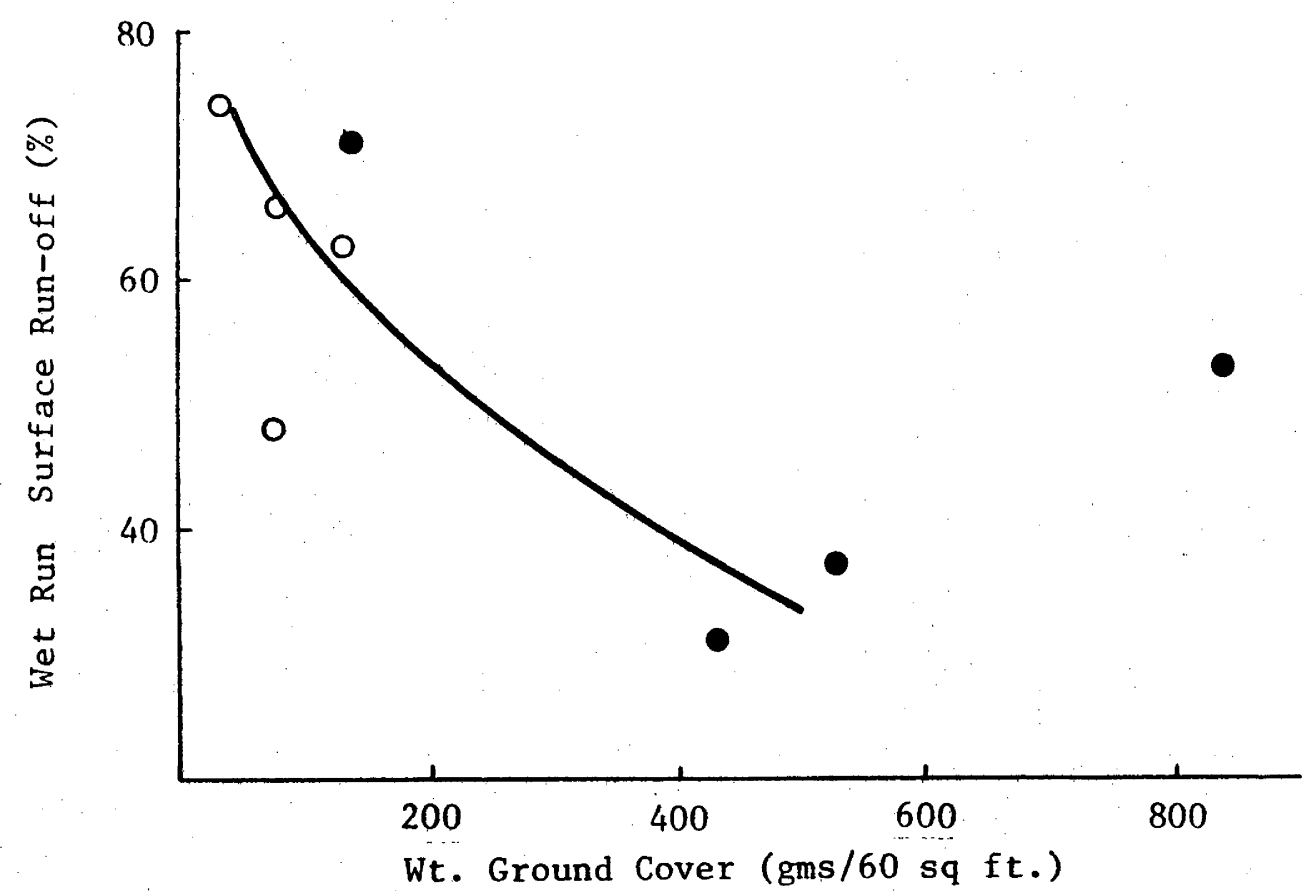

Figure 28. Relation between surface run-off and ground cover (for an artificial rainfall of 80 points in 15 minutes). 
non-significant due to the high variability within sites. However, certain tendencies were evident, and these are discussed below.

\section{Site A}

The mean surface run-off was higher for pines than for eucalypts (13.3 and $9.7 \%$ respectively), in spite of the fact that there was little difference in weight of cover between the two. However, most of the cover in the eucalypts was concentrated on two of the plots, whereas the pine plots had a more even distribution. This was more evident by comparing $\%$ cover - $97 \%$ for the pines and $71 \%$ for the eucalypts. Total porosity was the same for both, but capillary porosity was lower and non-capillary porosity higher for the pines than for the eucalypts. All things considered, the runoff from the pines should have been lower than from the eucalypts. The only conclusion that could be reached, is that there was a stronger hydrophobic effect in the pines than in the eucalypts. This is in keeping with the results presented in Section 2(e) of this chapter. This conclusion was also supported by comparing the constant infiltration rates, 111 and $170 \mathrm{pts} / \mathrm{hr}$ for the dry run for pines and eucalypts respectively and 118 and $197 \mathrm{pts} / \mathrm{hr}$ for the wet run.

Soil loss for the year was very low from the pines (44 g/plot), but high from the eucalypts $(368 \mathrm{~g} / \mathrm{plot})$. However. most of the soil from the eucalypts came from two poorly covered plots with only 28 and $57 \%$ cover.

In general, the eucalypts provided higher infiltration rates than the pines (in spite of the paucity of cover), while the pines provided better protection to the soil. The area of 
eucalypts where the plots were located had been burnt by a wildr fire early in 1957, so the ground cover had only accumulated over a period of seven years. The cover (mainly leaf litter) was very uneven because of the scattered nature of the dry sclerophyll forest. Areas beneath tree crowns were well covered with litter, while some areas between crowns were only sparsely covered.

\section{$\underline{\text { Site B }}$}

Mean surface run-off was low for both pines and eucalypts (4.3 and $2.3 \%$ respectively), in keeping with the fact that all plots were well covered. The pines were planted in 1953, and canopy closure had occurred. As a result the ground was well covered with a dense layer of pine needles. Infiltration rates were significantly lower for the pines than for the eucalypts (155 and $272 \mathrm{pts} / \mathrm{hr}$ respectively for the dry run and 163 and $279 \mathrm{pts} / \mathrm{hr}$ for the wet run). This could have been caused by the stronger hydrophobic effect of the pine litter or because the subsurface non-capillary porosity was lower for the pines than for the eucalypts (20 and 29\% respectively). The reason the differences in infiltration were not reflected by a larger difference in the mean surface run-off for the year could be because the dense pine canopy was more effective in intercepting natural rainfall than the sparse eucalypt canopy. This would result in less water reaching the ground and consequently the amount of run-off would be deceptively low.

No soil loss occurred from any of the plots during the year because they were all well covered. 
In general, both pines and eucalypts provided good protection against soil and water losses.

Site C

Mean surface run-off was at a very low level for both pines and eucalypts (2.5 and $2.1 \%$ respectively), in spite of the fact that two of the pine plots were very poorly covered (55 and 62\% cover). The plantation was established in 1957 and the weight of ground cover was significantly lower than for the eucalypts $(1,570 \mathrm{~g} / \mathrm{plot}$ compared with $4.940 \mathrm{~g} / \mathrm{plot})$. Surface and subsurface values of non-capillary porosity were high (30 and $33 \%$ for surface and 19 and $22 \%$ for subsurface); which probably accounted for the low run-off on partially bare plots. Infiltration rates were extremely high, being in excess of $303 \mathrm{pts} / \mathrm{hr}$ for the pines and $292 \mathrm{pts} / \mathrm{hr}$ for the eucalypts.

No soil loss occurred from any of the plots during the year's observations, probably because of the very low surface run-off, and the coarse permeable type of soil.

In general。 both pines and eucalypts provided excellent protection against soil and water losses even when the soil was not completely covered.

$\underline{\text { Site D }}$

Mean surface run-off was much higher for the pines than for the eucalypts $(20.3$ and $9.1 \%$ respectively). This is in keeping with the low cover on the pine plots $(2,160 \mathrm{~g} / \mathrm{plot}$ and $47 \%$ ) compared with the eucalypt plots $(4,010 \mathrm{~g} / \mathrm{plot}$ and $79 \%)$. Probably as a result of the large amount of bare space in the pine plots bulk density was higher and non-capillary porosity 
lower than in the eucalypt plots. Infiltration rates were also lower for the pines than for the eucalypts. The pine plantation was planted in 1960 on a site which appears to be very infertile. As a result the ground cover was still very incomplete even after four years.

Soil loss was high for the pines $\left(1_{8} 328 \mathrm{~g} / \mathrm{plot}\right)$ and low for the eucalypts ( $99 \mathrm{~g} / \mathrm{plot})$; again because of the low cover on the pine plots. Most of the soil loss in the eucalypts came from one plot with only $28 \%$ cover. This area of eucalypts was burnt with the plantation burn in 1960, and a few small areas were still incompletely covered.

In general, the eucalypts provided adequate protection against soil and water losses, but the pines did not.

Figure 29 shows the disposition of infiltrated water, surface run-off and soil loss for both pines and eucalypts at each of the four sites for the study year. It can be seen that there are differences in the behaviour of the natural communities, and that the differences become accentuated after plantation establishment. It appears that areas with highly permeable surface and subsoil return to their near original behaviour a short time after disturbance. This is borne out by the observation that bare firebreaks in areas of highly permeable soils show little evidence of surface washing or scouring. In contrast to this, areas where the permeability of the subsoil is low take a considerable length of time to return to the near natural condition. This is because they have to build up non-capillary porosities in the 

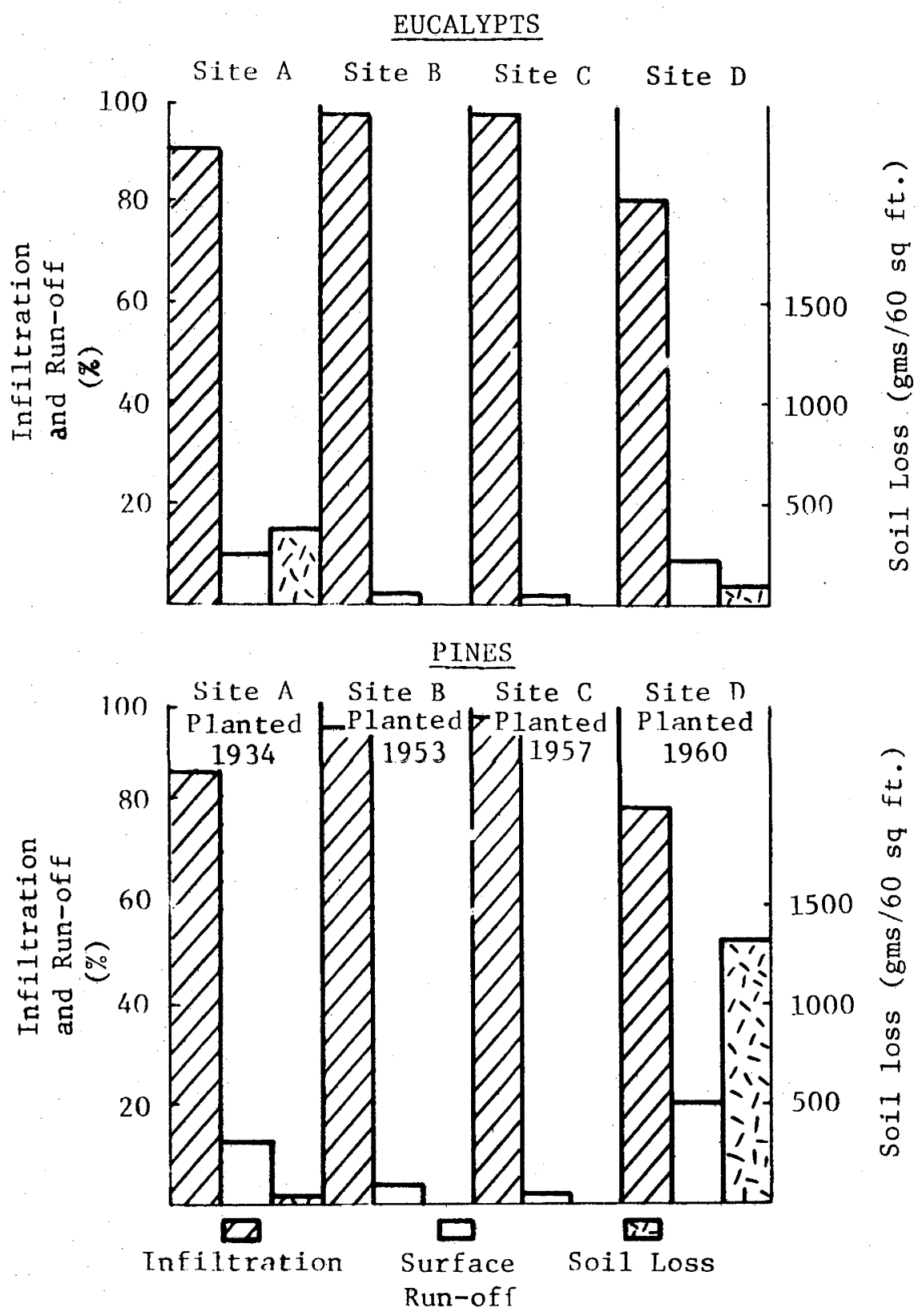

Figure 29. Disposition of infiltrated water, surface run-off and soil loss for Pines and Eucalypts at each site for the study year. 
surface soil to enable them to absorb most of the rainfall. This build up is brought about by additions of organic matter, earthworm activity, etc. 


\section{CHAPTER 3}

\section{DISCUSSION}

The objectives of the study were twofold: to determine the influences of soil and vegetation on infiltration, surface run-off and soil loss; and to determine ground cover requirements necessary to keep soil and water losses at a minimum. The results presented in the previous chapter show how ground cover and noncapillary porosity control surface run-off and soil loss.

The general nature of the interaction between noncapillary porosity and surface run-off is shown in diagrammatic form in Figure 30. Areas with high surface non-capillary porosity produced low surface run-off for most of the rainfall encountered, regardless of the subsoil non-capillary porosity. This was because the detention storage space in the surface was sufficient to detain most of the watêr. Hôwêver, areas with high surface non-capillary porosity and low subsoil non-capillary porosity produced medium values of surface run-off from prolonged high intensity rainfall. The combination of low surface noncapillary porosity and medium subsoil non-capillary porosity did not occur: but such a combination would be analagous to having a sheet of plastic with a few holes in it on top of a large sponge. The rate of water intake would be determined by the rate of movement through the plastic. Similar relationships between infiltration and non-capillary porosity of the various soil horizons have been reported by several other workers (e.g. Free et al. 1940; Lassen et al. 1952; Dortignac and Love 1961). 


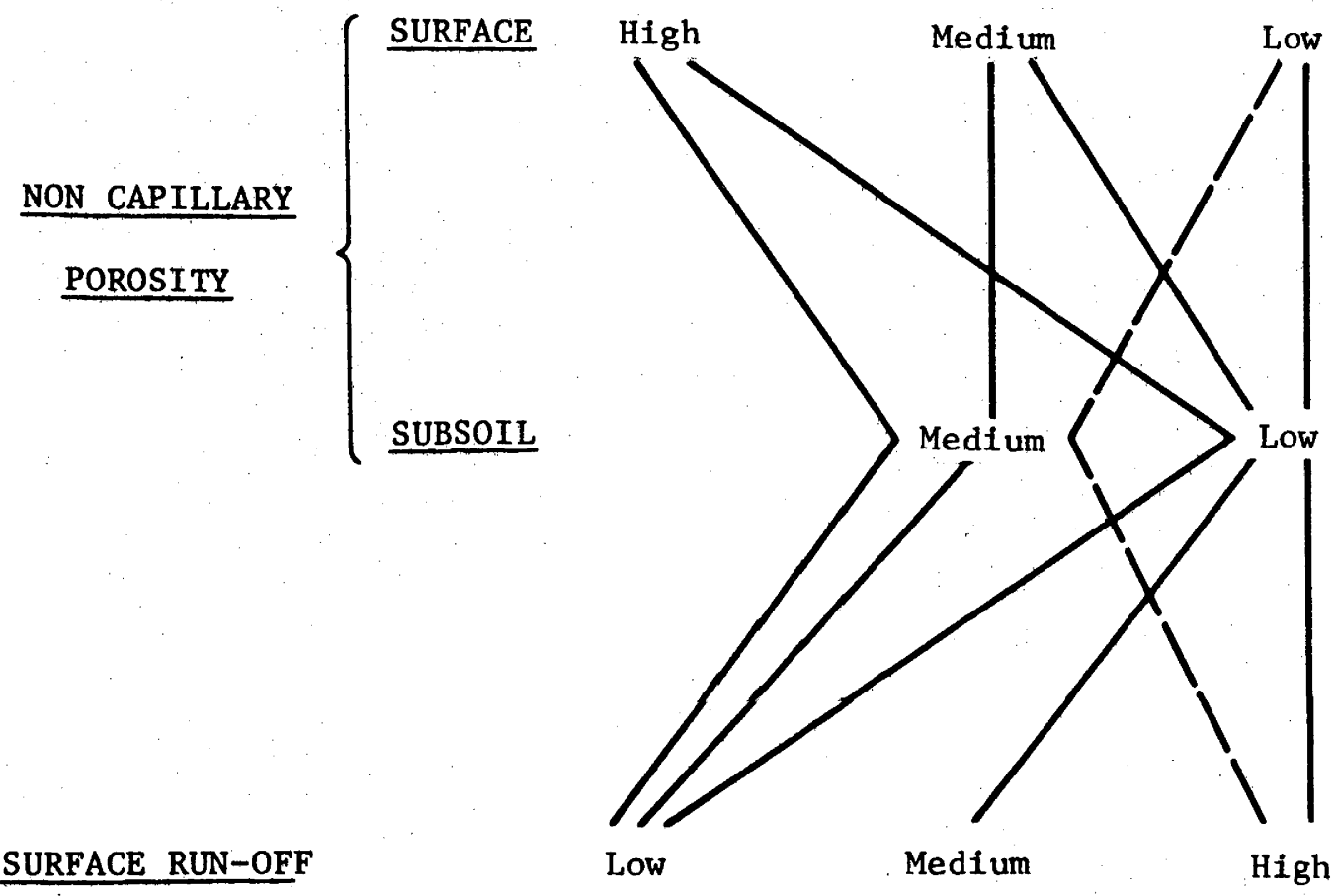

Figure 30. Diagram showing surface run-off for different combinations of surface and subsoil non capillary porosity. 
In areas of low subsoil non-capillary porosity (i.e. areas where surface run-off varied with the surface non capillary porosity) ground cover operated on the above interaction in two ways :

1. by influencing surface non-capillary porosity;

2. by acting as a mechanical barrier to the flow of surface water.

The first effect was shown to be the more important one under conditions of the present study (cf. Figure 25). However, work in other areas has suggested the greater importance of the mechanical impedence of cover in controlling surface run-off (Costin et al. 1960). Most of the reported work on infiltration and run-off has indicated relationships between infiltration and ground cover over a wide range of conditions; e.g. in agricultural areas: Duley and Kelly (1939); Duly and Russell (1939); Mannering and Meyer (1963); and in natural and semi-natural communities: Smith and Leopold (1942); Packer (1951); Orr (1957). However, only a few workers have shown quantitative relationships between ground cover and non-capillary porosity (e.g. Lassen et al. 1952; Baver 1956).

No relationship between ground cover and surface runoff was apparent in areas with medium values of subsoil noncapillary porosity. Surface run-off was low at all times due to the relatively high non-capillary porosity throughout the profile. The above results lead to the conclusion that noncapillary porosity is the most important single soil factor in controlling infiltration and surface run-off. Other investigators 
(Dortignac and Love 1961) have reached similar conclusions. The range in values of the parameters measured at each of the four sites is shown in a semi-quantitative manner in Table 14. For the parameters of surface run-off, infiltration and surface and subsoil non-capillary porosity, the four sites segregated into two distinct groups. Sites B and C had medium values of subsoil non-capillary porosity, and surface run-off was low, while infiltration rates were high. Sites $A$ and $D$ had low values of subsoil non-capillary porosity and surface run-off varied from low to high depending on the surface non-capillary porosity. Infiltration rates also varied from low to high. Soil loss (Table 14) also showed segregation into two groups - sites A and D with variable soil loss and sites B and C with negligible soil loss. The soil loss at sites $A$ and D varied with the amount of ground cover (cf. Figure 16); a trend which is in keeping with the results of other workers (e.g. Forsling 1931; Meginnis 1935; Packer 1951; Kawaguchi and Takiguchi 1953; 0sborn 1954). However, soil loss at sites B and $C$ was negligible even on plots with low amounts of ground cover. This finding is in contrast with most of the reported work, and is probably due to the low surface run-off, which in turn is related to the coarse permeable type of soil at these two sites.

The implications of this segregation into two groups are important from a practical viewpoint. Sites $A$ and $D$ are very sensitive to decreases in ground cover below $4.000 \mathrm{~g} / 60 \mathrm{sq} . \mathrm{ft}$. and they should be managed to maintain at least this amount of cover. 
The pine plantation at site $D$, although 4 years old, still had insufficient cover for complete soil stability. In fact it is probable that such an area would have been better managed as a native forest fulfilling a protective function.

TABLE 14

Semi-quantitative range of the parameters measured at each site.

\begin{tabular}{|c|c|c|c|c|c|}
\hline \multirow[t]{2}{*}{ Parameter } & \multirow[t]{2}{*}{ Range } & \multicolumn{4}{|c|}{ Site } \\
\hline & & A & B & C & D \\
\hline $\begin{array}{l}\text { Surface } \\
\text { run-off }\end{array}$ & $\begin{array}{l}\text { Low } \\
\text { Medium } \\
\text { High }\end{array}$ & $\begin{array}{l}\mathbf{x} \\
\mathbf{x} \\
\mathbf{x}\end{array}$ & $\mathbf{x}$ & $\mathbf{x}$ & $\begin{array}{l}\mathbf{x} \\
\mathbf{x} \\
\mathbf{x}\end{array}$ \\
\hline $\begin{array}{l}\text { Infiltration } \\
\text { rates }\end{array}$ & $\begin{array}{l}\text { Low } \\
\text { Medium } \\
\text { High }\end{array}$ & $\begin{array}{l}\mathbf{x} \\
\mathbf{x} \\
\mathrm{X}\end{array}$ & $\mathbf{x}$ & $\mathbf{x}$, & $\begin{array}{l}\mathbf{x} \\
\mathbf{x} \\
\mathbf{x}\end{array}$ \\
\hline $\begin{array}{l}\text { Surface non- } \\
\text { capillary } \\
\text { porosity }\end{array}$ & $\begin{array}{l}\text { Low } \\
\text { Medi um } \\
\text { High }\end{array}$ & $\begin{array}{l}\mathbf{x} \\
\mathbf{x} \\
\mathbf{x}\end{array}$ & $\begin{array}{l}\mathbf{X} \\
\mathbf{x}\end{array}$ & $\begin{array}{l}\mathbf{X} \\
\mathbf{x}\end{array}$ & $\begin{array}{l}x \\
x \\
x\end{array}$ \\
\hline $\begin{array}{l}\text { Subsoil non- } \\
\text { capillary } \\
\text { porosity }\end{array}$ & $\begin{array}{l}\text { Low } \\
\text { Medi um }\end{array}$ & $\mathrm{x}$ & $\mathrm{x}$ & $\mathbf{x}$ & $\mathbf{x}$ \\
\hline Soil loss & $\begin{array}{l}\text { Low } \\
\text { Medium } \\
\text { High }\end{array}$ & $\begin{array}{l}\mathbf{x} \\
\mathbf{x} \\
\mathbf{x}\end{array}$ & $=\mathbf{x}$ & $\mathbf{x}$ & $\begin{array}{l}\mathbf{x} \\
\mathbf{x} \\
\mathbf{x}\end{array}$ \\
\hline $\begin{array}{l}\text { Weight } \\
\text { ground cover }\end{array}$ & $\begin{array}{l}\text { Low } \\
\text { Medium } \\
\text { High }\end{array}$ & $\begin{array}{l}\mathbf{x} \\
\mathbf{x} \\
\mathbf{x}\end{array}$ & $\begin{array}{l}x \\
x\end{array}$ & $\begin{array}{l}\mathbf{x} \\
\mathbf{x} \\
\mathbf{x}\end{array}$ & $\begin{array}{l}\mathbf{x} \\
\mathbf{x} \\
\mathbf{x}\end{array}$ \\
\hline
\end{tabular}

Site D is typical of many of the steep north and west facing slopes in the north-western portion of the catchment. The soil fertility appears very low and most of the nutrient capital is probably tied up in the standing vegetation and the surface soil. 
Clearing and burning would result in the loss of a large part of this capital leaving the soil with an even lower fertility, and revegetation would be slow. Raindrop action and compaction by tractors would reduce the surface detention storage, and since the detention storage of the subsoil is naturally low, surface run-off would increase resulting in a marked increase in soil movement. This is quite evident in Wombat Creek catchment bel ow site D. Beaver dams constructed across dry watercourses at plantation establishment are filled with debris and many have broken through and produced severe gullying. The dam shown in Plate 33 is at the outlet of a catchment of 7.5 acres and contained about 2,500 cubic feet of soil material, most of which was probably deposited in the first few months after clearing and burning. The volume of soil is conservative, as the dam was full, and an unknown amount of soil must have been washed over the top. Another example is seen in Plate 34 which is in Lee's Creek catchment. An estimated 9,900 cubic feet of soil material was removed from the scour during one storm and deposited in and around Lee's Creek itself.

The areas referred to above were probably subjected to late Pleistocene periglacial activity and the continual freezethaw cycles resulted in a great deal of the soil mantle being moved from the slopes to the gullies (Costin 1954). The result is that the ridges and slopes consist of shallow infertile soils while the gullies are filled with deep deposits of moderately fertile undifferentiated soils. This is a fortunate circumstance, as the gully soils revegetate fairly quickly and act as silt traps 


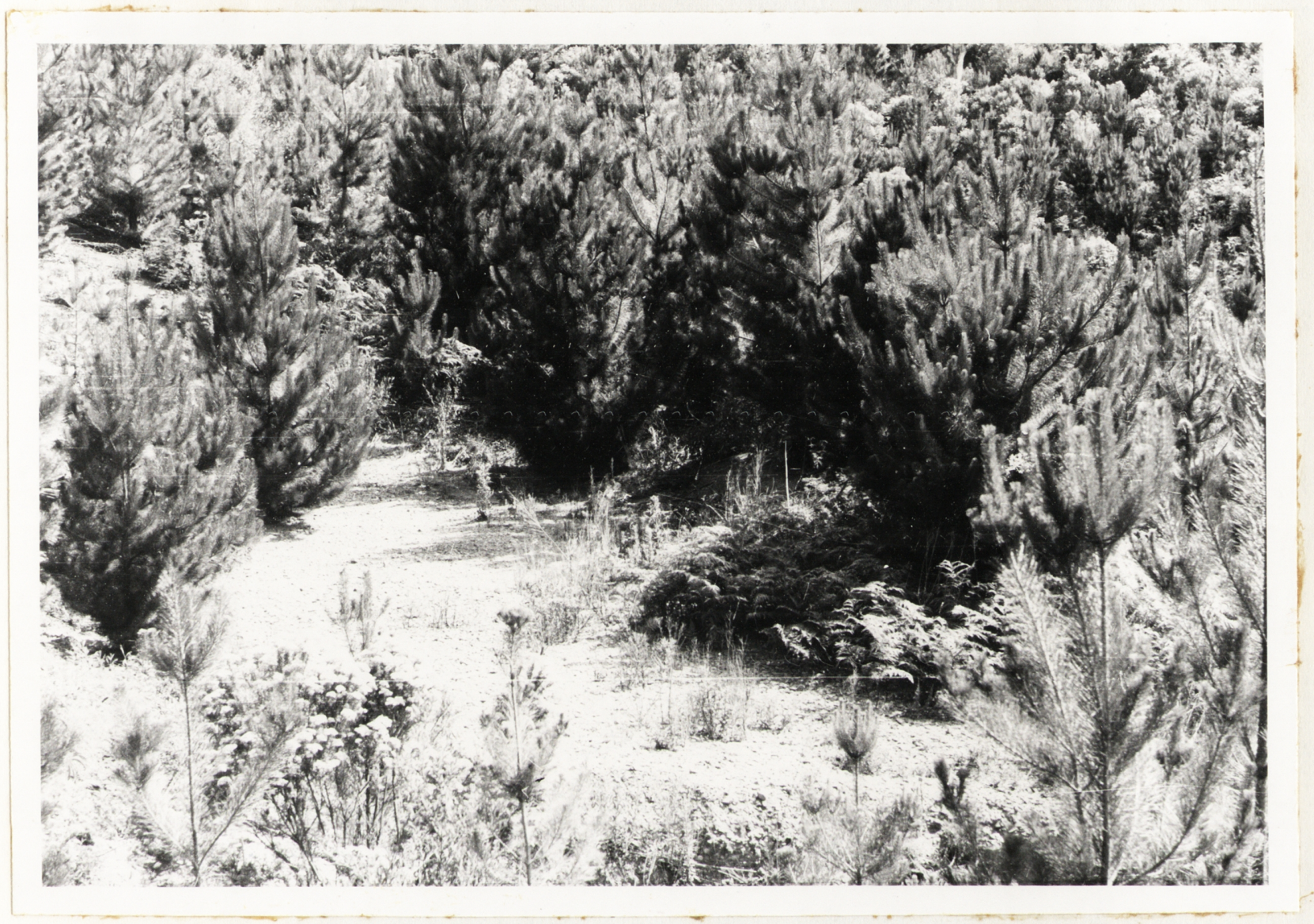

PLATE 33. Beaver dam below site D containing approximately 2,500 cubic feet of soil material. 


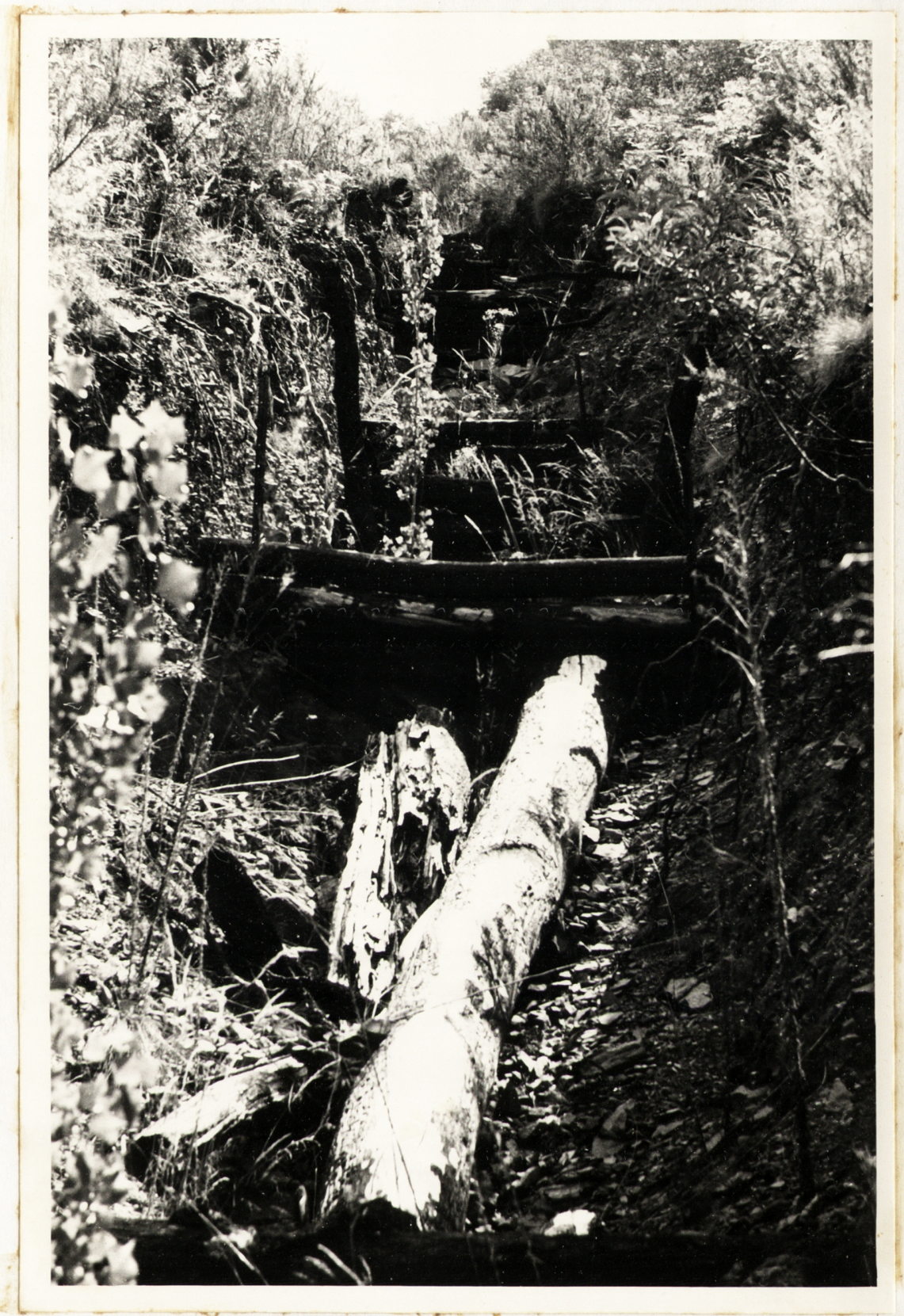

PLATE 34. Scour in Lees Creek catchment from which approximately 9,900 cubic feet of soil material were removed during one storm. 
to sediment laden flows from higher slopes. This is probably the reason why no high sediment loads were detected in Wombat Creek during 1963 and 1964, even though there were actively eroding areas such as site D on the upper slopes. Even so, it is doubtful if such infertile areas should have been converted from native forests to pine plantations under existing management practices, as large amounts of soil material must have been deposited in the watercourse during the first year after clearing and burning.

If areas such as site $D$ are to be converted to plantations it would be advantageous to investigate the possibility of raising the fertility level of the soils inorder to hasten revegetation; and of manual rather than mechanical methods of clearing and site preparation.

Sites $B$ and $C$ showed little reaction to decreases in ground cover because of the favourable soil conditions of medium to high non-capillary porosity throughout the profile. Such areas can probably be converted to pine plantations quite safely, provided adequate precautions are taken against compaction. In other studies compaction effects have been found to be important in reducing the non-capillary porosity of the surface soil. with resultant increases in surface run-off (e.g. Alderfer and Robinson 1947: Orr 1960; Tackle 1962).

It has been shown that on gentle slopes, careful prescribed burning can be carried out in pine plantations without producing any decrease in infiltration rates or increase in soil movement. Ground cover at the rate of $3.690 \mathrm{~g} / 60 \mathrm{sq}$. $\mathrm{ft}$. $(2.6$ tons/acre) was left unburnt; and this amount was sufficient to 
keep soil and water losses at a minimum. Most of the effects of fire reported in the literature have been related to wildfires or to high intensity controlled fires which completely burnt the ground vegetation. The effects of such fires on infiltration and soil loss have been mainly deleterious (e.g. Sampson 1944; Anderson 1949; Costin et al. 1960). However. there have been several reports of increases in infiltration following burning (e.g. Veihmeyer and Johnston 1944; Scott 1956). The possible loss of mineral nutrients in the run-off water from rain following burning could represent an important loss of the nutrient capital, particularly in areas of low fertility. In addition to the losses measured in this study, losses of nitrogen and sulphur by volatilization during the fire may also be of significance. It was shown (Table 11) that the most damaging loss by washing would occur if a run-off producing rain occurred immediately after the fire; and run-off from subsequent rains would be markedly lower in nutrients. If the first rainfall after a fire was a low intensity one most of the nutrients would probably be washed into the soil surface and little loss by later run-off producing rains would occur. Burning changes organic complexes of phosphorus and potassium into forms more readily available for plant use (Kittredge 1948). The rapid increase in availability of nutrients following burning would probably result in increased activity of the soil microorganisms, and possibly a slight increase in vegetation growth. Several workers have reported an increase in the nutrient level of surface soils following annual burning 
(e.g. Heyward and Barnette 1934; Metz et al. 1961). Florence (personal communication) in a 12 year study of annual burning. reported an initial increment advantage of annually burnt trees. then a loss of the advantage towards the end of the period. The foliage of annually burnt trees was lower in nitrogen and phosphorus than that of protected trees (at the end of the 12 years period), and levels of soil nitrogen and phosphorus showed similar trends. This indicates that the release of nutrients after burning resulted in an initial flush of growth, but the nutrient capital was eventually depleted to a low level.

The effects of prescribed burning in eucalypt forests were not investigated in this study, but observations suggest that such operations would remove most of the litter and shrub layers. The bared soil would then be prone to damage by increased surface run-off。 and nutrient losses could be high. However, this aspect should be the subject of further study. Data on soil loss do not give a clear picture of the nature of nutrient loss, as it was found that the concentration (but not the total amount) of nutrients was highest in the soil lost from plots with high weights of ground cover. As a result. small amounts of soil loss from reasonably well covered plots could represent quite high nutrient loss. This indicates that complete soil stability is necessary for full catchment protection, and it has been shown that ground cover at the rate of $4.000 \mathrm{~g} / 60 \mathrm{sq} . \mathrm{ft}$. will provide this protection at sites $A$ and $D$. (No soil loss occurred at sites $B$ and $C$, even on areas with low amounts of cover). 
Most of the soil washed from the plots was very fine material; and it is the fine material in soil that contains most of the mineral nutrients (Bennett 1939). Recent work by Hamilton (1964) in the Cotter catchment has shown a fertility gradient from the low altitude dry areas to the high altitude moist areas. The concentrations of total nitrogen and total phosphate at each end of the gradient are shown in Table 15.

TABLE 15

Nutrient status of the surface inch of soils at each end of a fertility gradient in the Cotter catchment. (After Hamilton 1964)

\begin{tabular}{|l|c|c|}
\hline \multirow{2}{*}{ Site } & \multicolumn{2}{|c|}{ Nutrient Concentration } \\
\cline { 2 - 3 } & $\begin{array}{c}\text { Total nitrogen } \\
(\%)\end{array}$ & $\begin{array}{c}\text { Total phosphate } \\
(\mathrm{p} . \mathrm{p} . \mathrm{m} .)\end{array}$ \\
\hline $\begin{array}{l}\text { Low altitude } \\
\text { dry sclerophyl1 } \\
\text { forest }\end{array}$ & 0.12 & 526 \\
$\begin{array}{l}\text { High altitude } \\
\text { wet sclerophyll } \\
\text { forest }\end{array}$ & 0.32 & 1.526 \\
\hline
\end{tabular}

The fertility level of the soils at sites A and D would probably be towards the lower end of the gradient mentioned above. However, the average concentration of nutrients in the soil los from sites $A$ and $D$ was considerably higher than their concentration in the surface inch of soil at comparable areas (Table 16). Table 16 indicates that fertility erosion is more severe than the soil erosion figures infer, e.g. from data in Table 16, a given weight of soil loss would contain three times the amount of nitrogen and twice the amount of phosphate as the 
same weight of soil in situ.

TABLE 16

Levels of nitrogen and phosphate in surface soil at the lower end of a fertility gradient and in the soil loss from comparable areas

\begin{tabular}{|l|c|c|}
\cline { 2 - 3 } & \multicolumn{2}{|c|}{ Nutrient } \\
\cline { 2 - 3 } & $\begin{array}{c}\text { Total nitrogen } \\
(\%)\end{array}$ & $\begin{array}{c}\text { Total phosphate } \\
\text { (p.p.m.) }\end{array}$ \\
\hline $\begin{array}{l}\text { Average concentration of } \\
\text { nutrients in surface } \\
\text { inch of soil at lower } \\
\text { end of gradient } \\
\text { (after Hamilton) }\end{array}$ & 0.12 & 526 \\
$\begin{array}{l}\text { Average concentration of } \\
\text { nutrients in soil loss } \\
\text { at sites A and D }\end{array}$ & 0.38 & 1.098 \\
\hline
\end{tabular}

The relatively high concentration of potassium in the soil loss (average of $1.76 \%$ for all plots which lost soil) could be due to its mobility and the fact that it is leached from living and dead vegetation by rain. Recent work in the Snowy Mountains by Costin and Wimbush (1961) has shown that rainwater collected from under trees contained higher concentrations of potassium than rainwater collected in the open.

It has been shown that soils with a well developed ground cover of pine needles have slightly lower infiltration rates than soils with a comparable weight of eucalypt ground cover (cf, Figure 24). The forest floor under pines is well enough protected so that no erosion would occur from the higher run-off。 but it may be of importance in increasing erosion on bare roads and firebreaks. However, the forest floor under pines reaches a high level only after canopy 
closure has occurred (Hamilton 1964). Hamilton (1964) also found that pine crowns (after closure) intercepted more rainfall than adjacent dry sclerophyll eucalypt crowns. Consequently any real differences in infiltration would tend to be nullified by the differences in interception.

Various studies have shown that infiltration is more rapid in dry than in wet soils (e.g. Colman and Bodman 1944; Horton 1945; Rowe 1948; Tisdall 1951; Philip 1957) . However, the results of this study have shown that soils with high amounts of ground cover have lower infiltration rates when dry than when wet (cf. Figure 24). This is probably due to some hydrophobic agent which is associated with the finely divided organic matter at the soil - littèr interface. Similar hydrophobic effects have been reported elsewhere (e.g. Jamison 1945, 1946; Van't Woudt 1959: Bond and Harris 1964; Bond 1964; Hamilton 1964). Most of these hydrophobic effects have been reported from laboratory or plot scale investigations, but no such effects have been noticed on a catchment scale. The practical implications would probably be very local ones, e.g. high surface run-off from a well vegetated dry area, as a result of a hydrophobic action, could cause erosion of adjacent bare roads and firebreaks.

Although slight differences in efficiency of protection occurred between well established pine and eucalypt forests, the differences were small when compared with the behaviour of bare areas such as firebreaks. This is indicated in Figure 31 which shows the monthly soil loss pattern for pines and eucalypts at site $A$ and for the firebreakplot All which is located between 


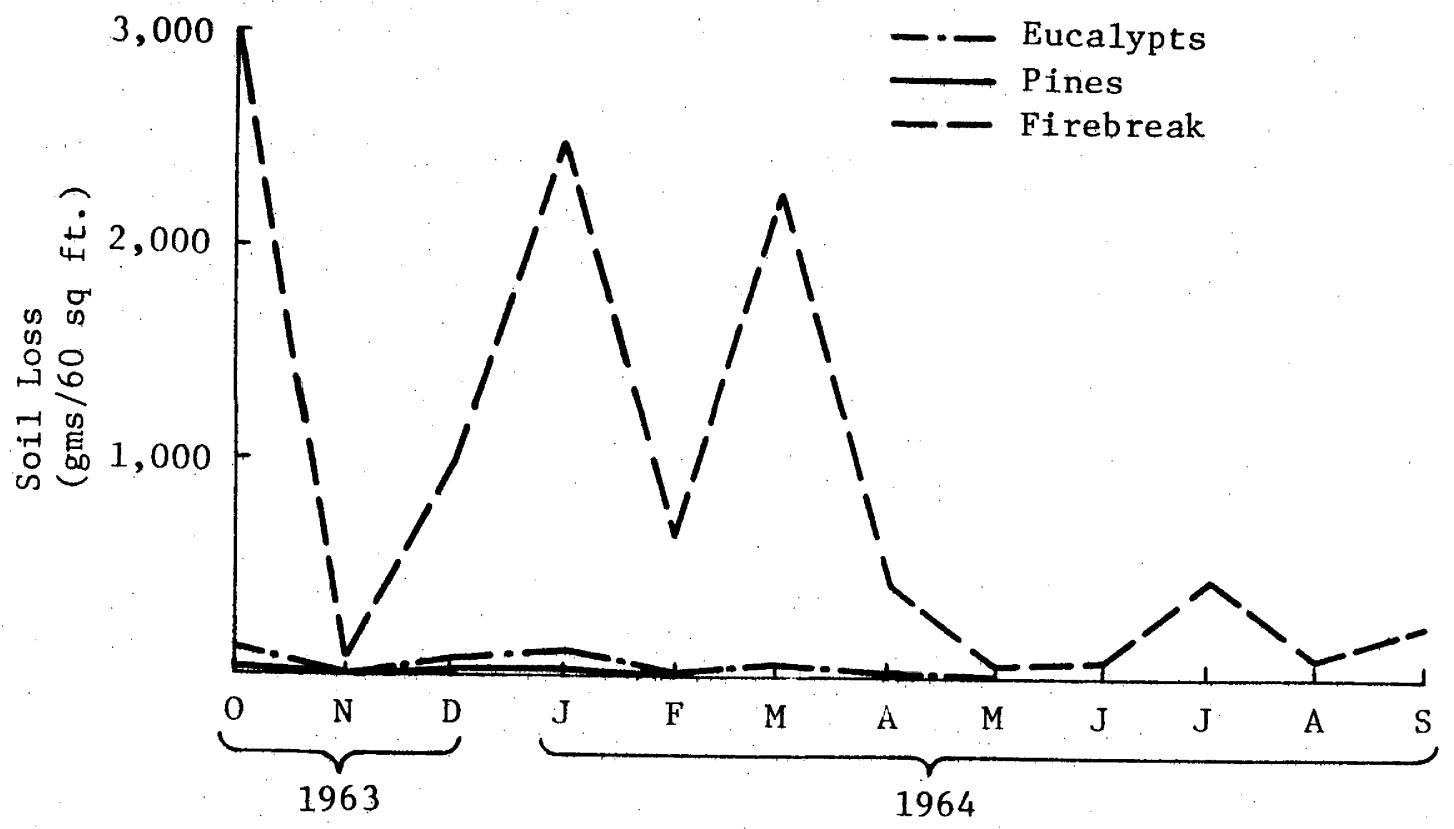

Figure 31. Monthly soil loss pattern at site A. 
the two vegetation types.

The very high value of $60 \%$ for surface run-off from the firebreak plot mentioned above has important consequences. Such a large amount of surface water has great potential for erosion. not only where it originates, but in normally stable areas nearby. This is shown in Plates 35 and 36. Surface run-off originating from the partly bare firebreak in Plate 35 produced considerable scouring downslope as shown in Plate 36. This particular area is in Pierce's Creek Forest, and the scour is on a steep slope about thijee chains above the Cotter River. Each time heavy rain falls sediment laden run-off pours down this scour directly into the river. The importance of relatively small areas in contributing more than their share, on an area basis, of soil and water losses has been mentioned by other workers (e.g. Marston 1952; Betson 1964).

Firebreaks such as the one described above are graded periodically and in many cases all the Al horizon and much of the A2 horizon has been removed. Add raindrop compaction to this and the result is an almost impermeable area. Firebreak plot All has a bulk density of $1.78 \mathrm{~g} / \mathrm{c.c}$. and a non-capillary porosity of $9 \%$ in the surface two inches. Consequently there is hardly any space for rainwater to enter the soil, and most of it runs off. Roads are probably an even greater source of surface run-off, as compaction is increased by the passage of vehicles. The introduction of vegetation to these areas would result in a moderate decrease in surface run-off and a large decrease in soil loss. This was shown by the substantial reduction 


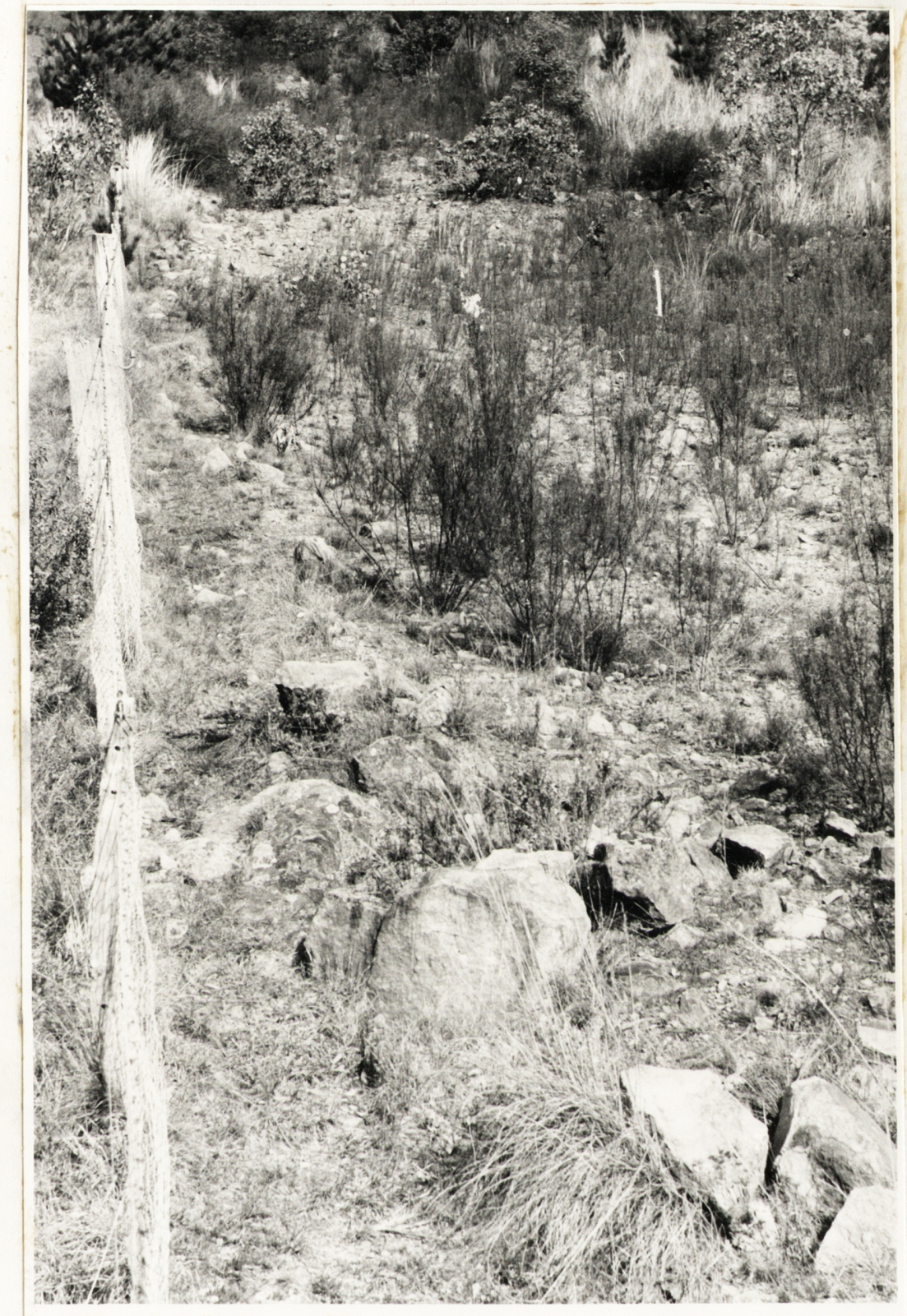

PLATE 35. Surface run-off from the partly bare firebreak shown in this plate produced the scour shown in Plate 36 . 


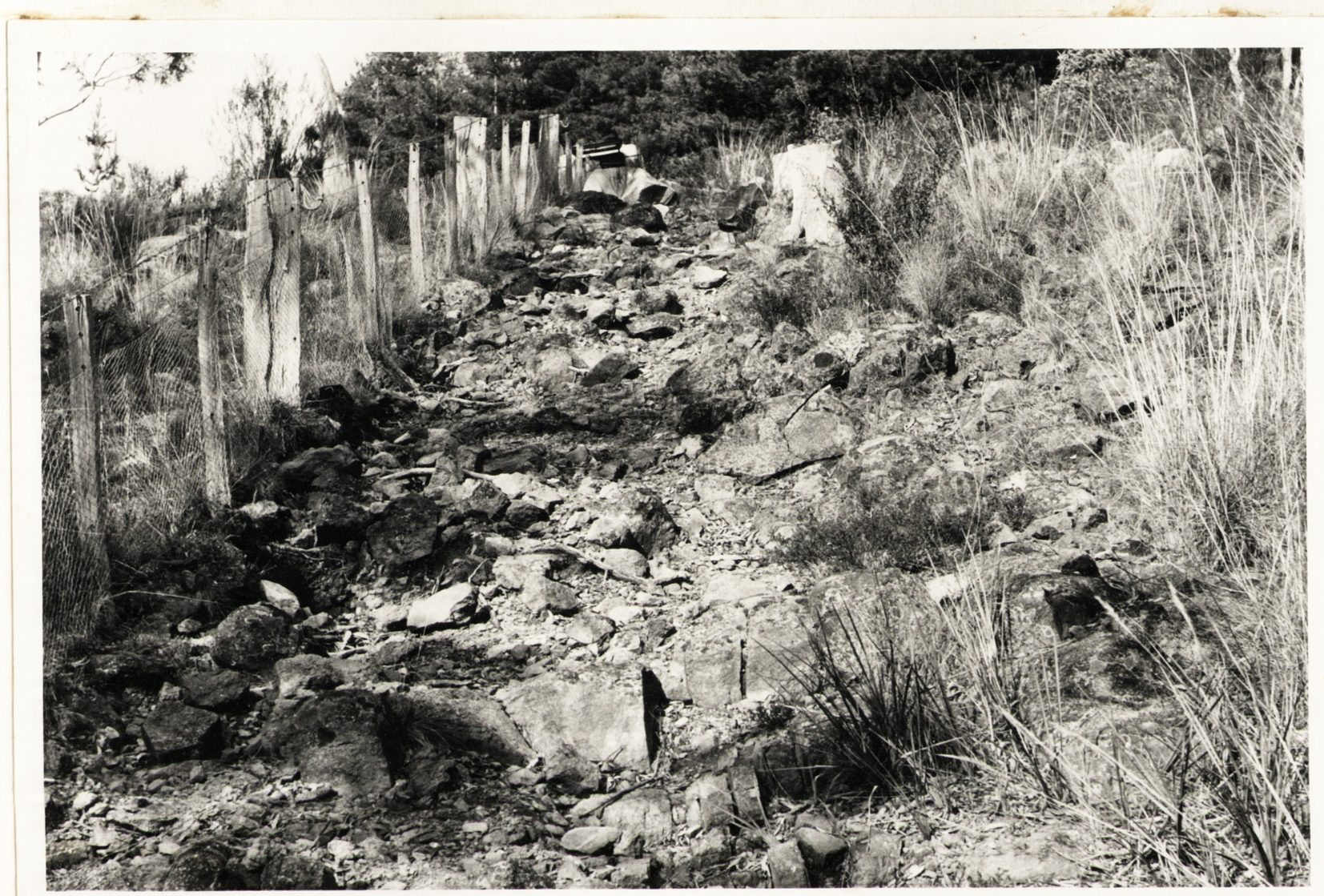

PLATE 36. Scour caused by surface run-off from the firebreak shown in Plate 35. 
in soil and water losses which occurred after clover was grown on a steep firebreak in Pierce's Creek Forest (cf. Figures 27 and 28). Turbidity studies in some of the streams of the lower Cotter catchment have shown that bare areas are positive sources of sedimentation (Lamb 1965). Figure 32 (based on Lamb's data) shows stage heights and turbidity levels for two sampling points on a tributary of Coree Creek following a rainfall of 74 points. An unsealed main road crosses the stream over a culvert between the two points. The stage height at both points was similar. but the peak turbidity level at the point below the road was 120 units higher than the peak level above the road; indicating that sediment laden run-off from the road was the cause of the sudden increase in turbidity.

The combination of high intensity rains and dry surface soils makes the summer months the period of highest erosion hazard (cf. Figure 31). This suggests that disturbance of the catchment should be kept to a minimum during this period. Roading and grading should be minimised, and where necessary should be carried out in autumn or early spring so that there is time for the soil surface to settle down before high intensity rainfall becomes a common feature of the weather pattern.

Observations suggest that frost action is important in increasing soil movement at the higher altitudes where the formation of needle ice is a common phenomenon during the winter months (particularly on fine grained soils). It occurs on bare areas and may build up needles of five inches or more in height by successive freeze - thaw cycles (Plate 37). It forms just 


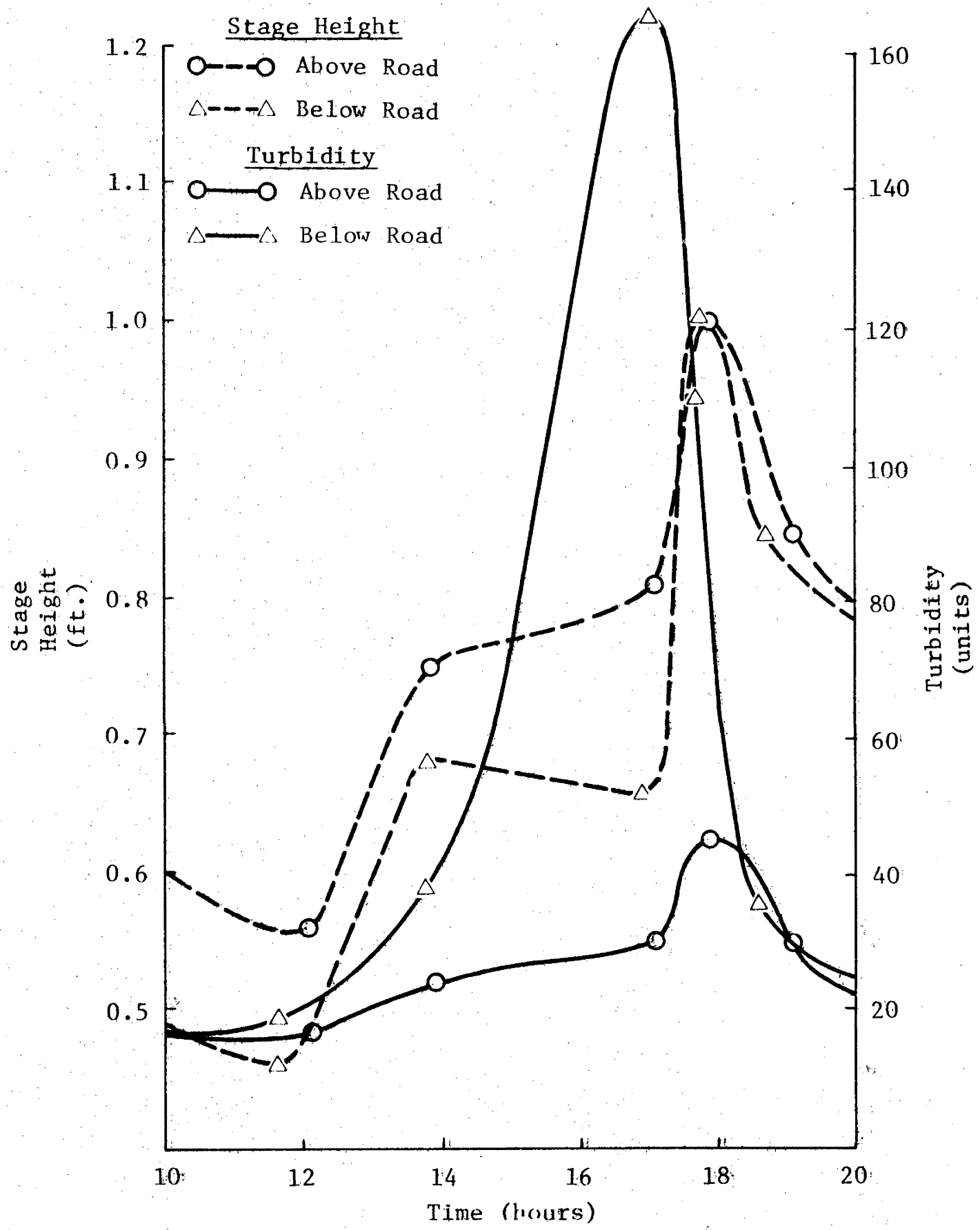

Figure 32. Turbidity levels and stage height above and below a road crossing on a tributary of Coree Creek. 


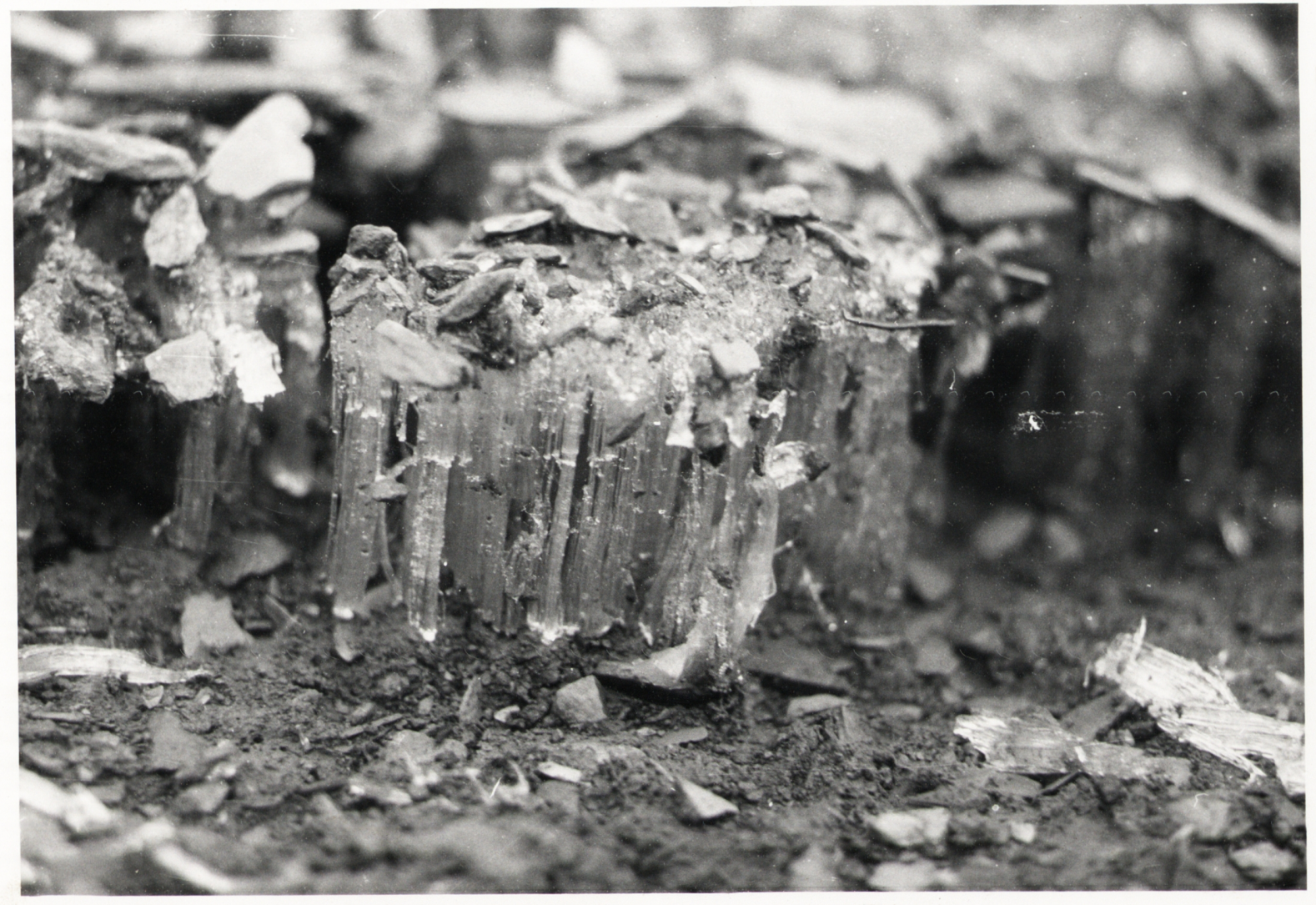

PLATE 37:' Soil surface lifted by needle ice formation $\left({ }^{2} / 3\right.$ naturaI size). 
beneath the soil surface and lifts the surface soil up with it. After the ice melts, the loose surface is in an ideal condition to be washed away by the first run-off producing rain.

The effect of frozen soil on snow melt run-off is in accordance with observations of other workers (e.g. Post and Dreibelbis 1942; Costin et al. 1960). However, the practical significance of high surface run-off from frozen soil is not very great in the Cotter catchment, as most of the area affected by severe freezing is well forested, and very little of it would be subjected to soil freezing effects.

It is advantageous to transpose the results of this study into general terms for use in catchment management. The results show that the ground cover present under native eucalypt forests and under well established pine plantations, irrespective of soil type, is sufficient to maintain the land surfaces in a stable condition with minimum soil and water losses.

Young pine plantations on soils with low values of non-capillary porosity in the subsoil do not provide sufficient protection from soil and water losses. Such soils appear to be infertile and are derived mainly from fine grained sedimentary parent materials; but further study is necessary to delineate their extent. The data indicate that $4,000 \mathrm{~g} / 60 \mathrm{sq} . \mathrm{ft} .(2.9$ tons/acre) is requilifed for maximum protection from soil and water losses on these soils. As far as possible catchment management techniques should be geared to this objective. 
Low amounts of ground cover on soils with high values of non-capillary porosity in the subsoil do not appear to result in any increase in soil or water losses. Such soils are generally derived from coarse grained igneous or volcanic parent materials and can be managed with less regard to ground cover. Plantation establishment and prescribed burning can probably be carried out quite safely on these soils providing care is taken to keep compaction to a minimum.

Most of the soil loss measured during the study came from large bare areas such as firebreaks and young pine plantations situated on soil types with low non-capillary porosity in the subsoil. Revegetation of such areas would substantially reduce soil and water losses.

\section{CONCLUS IONS}

The plot approach proved very satisfactory for investigating the influences of soil and vegetation on infiltration, surface run-off and soil loss.

In general, native eucalypt forest and well established pine plantations provided excellent catchment cover.

Newly established pine plantations in areas of low subsoil non-capillary porosity provided an unsatisfactory cover and some of them should have remained as native forest fufilling a protective function.

Bare areas such as firebreaks produced a major portion of the soil movement occurring on the land surfaces; and from a catchment point of view such areas should be revegetated as soon as possible. 
Although it is evident that an undisturbed forest offers the best protection to soil and water, it is also clear that all forests cannot remain in an undisturbed condition if full use is to be made of our forest lands. However, where water is the most important product of a catchment area, the management practices for the utilization of the other resources should be geared to the primary objective of sustained production of the maximum amount of usable water. If this objective is to be reached more information should be obtained on the hydrological effects of various management practices, so that catchments may be utilized with the minimum deterioration in quantity, quality and regime of the water.

\section{ACKNOWLEDGEMENTS}

I would like to acknowledge the help given to me by a number of persons during the compilation of this thesis.

It would not have been possible to undertake this project without the two years' leave so freely granted by the Queensland Forestry Department and the monetary grant made by the National Capital Development Commission. I gratefully acknowledge the contributions of these organizations.

Particular thanks are due to my supervisors. Professor L.D. Pryor of the Botany Department, and Dr. A.B. Costin of the Division of Plant Industry, C.S.I.R.O. Their interest and guidance in the work has made the term of the project a stimulating and rewarding experience.

The staff and research students of the Botany Department and members of the Ecology Section of the Division of Plant 
Industry, C.S.I.R.0. are thanked for their helpful discussions. Thanks are also due to Dr. C.H. Williams (C.S.I.R.O.) for the chemical analyses; Mr. J. Deans (C.S.I.R.O.) for the drying and weighing of the plot harvests; and Mr. F.W. Hely (C.S.I.R.O.) for help in the establishment of the clover trials. The help of Officers of the Forestry Section (Department of Interior) in making experimental areas available, is acknowledged.

Dr. D.A.N. Cromer (Forest Research Institute) is thanked for making available the photographs used for the title page and frontispiece; and Mr. A. Edwards is thanked for their preparation. Thanks are due to Mr. A.G. McArthur and Mr. N.P. Cheney (Forest Research Institute) for carrying out the prescribed burning in the pine plantation at Stromlo Forest. 


\section{REFERENCES}

Adams, J.E., Henderson, R.C., and Smith, R.M. (1959) . - Interpretations of run-off and erosion from field scale plots

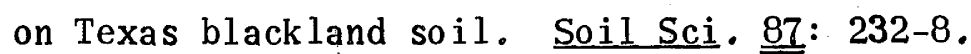

Alderfer, R.B., and Robinson, R.R. (1947) . - Run-off from pasture in relation to grazing intensity and soil composition. J. Amer. Soc. Agron. 39: 948-58.

Anderson, H.W. (1949). - Flood frequencies and sedimentation from forest watersheds. Trans. Amer, Geophys, Un. 30: $567-84$.

Arend, L.J., and Horton, R.E. (1943) . - Some effects of rain intensity, erosion and sedimentation on infiltration capacity. Proc. Soil Sci. Soc. Amer. 7: 82-9.

Auten, J.T. (1933) - Porosity and water absorption of forest soils. J.Agric. Res. 46: 997-1014.

Auten, J.T. (1934). - The effect of forest burning and pasturing in the Ozarks on the water absorption of forest soils. Central States For. Exp. Sta. Note 16.

Baver, L.D. (1956). - "Soil Physics" (Wiley : New York).

Bennett, H.H. (1939) . - "Soil Conservation" (McGraw-Hill : New York).

Betson. R.P. (1964) - What is watershed run-off? J.Geophys. $\underline{\text { Res. }}$ 우: 1541-52.

Blakely. W.F. (1955) . - "A key to the Eucalypts". (Forestry and Timber Bureau : Canberra).

Bond, R.D., and Harris, J.R. (1964). - The influence of the microflora on physical properties of soils. I. Effects associated with filamentous algae and fungi. Aust. J. Soil Res 2: $111-22$. 
Bond, R.D. (1964). - The influence of the microflora on the physical properties of soils. II. Field studies on water repellent sands. Aust, J, Soil Res. 2: 123-31.

Bouyoucos, G.J. (1936) . - Directions for making mechanical analyses of soils by the Hydrometer Method. Soil Sci. 르: 225-9.

Burbidge, Nancy T., and Gray, M. (1963). - The plants of the Australian Capital Territory (Advance copy). C.S.I.R.o. Div. Plant Ind.

Colman, E.A. (1953). - "Vegetation and Watershed Management". (Ronald : New York).

Colman, E.A., and Bodman, G.B. (1944) . - Moisture and energy conditions during downward entry of water into moist and layered soils. Proc. Soil Sci. Soc. Amer. 9: 3-11.

Costin, A.B. (1954) . - "A study of the ecosystems of the Monaro Region of New South Wales". (Govt. Printer : Sydney) .

Costin, A.B., Wimbush, D.J., and Kerr, D. (1960). - Studies in catchment hydrology in the Australian Alps. II. Surface run-off and soil loss. C.S.I.R.0. Aust. Div. Plant Ind. Tech. Pap. No.14.

Costin, A.B., and Wimbush, D.J. (1961). - Studies in catchment hydrology in the Australian Alps. IV. Interception by trees of rain, cloud, and fog. C.S.I.R.o. Aust. Div. Plant Ind. Tech. Pap. No.16. 
Craddock, G.W., and Pearse, C.K. (1938) . - Surface run-off and erosion on granitic mountain soils of Iidaho as influenced by range cover, soil disturbance, slope and precipitation intensity. Circ. U.S. Dep. Agric. No.482. Dortignac, E.J., and Love, L.D. (1961) . - Infiltration studies on Ponderosa Pine ranges of Colorado. Sta. Pap. Rocky Mtn. For. Exp. Sta. No.59.

Duley, F.L., and Kelly, L.L. (1939) . - Effect of soil type, slope and surface conditions on intake of water. Bull. Univ. Nebr. Agric. Exp. Sta. Res. No.112.

Duley, F.L., and Russell, J.C. (1939) . - The use of crop residues for soil and moisture conservation. J, Amer. Soc. Agron. $\underline{\text { 31: }}$ 703-9.

Forsling, C.L. (1931). - A study of the influence of herbaceous plant cover on surface run-off and soil erosion in relation to grazing on the Wasatch Plateau in Utah. Tech. Bull. U.S. Dept. Agric. No.220.

Free, G.R., Browning, G.M., and Musgrave, G.W. (1940) . Relative infiltration and related physical characteristics of certain soils. Tech. Bull. U.S. Dep. Agric. No.729.

Hamilton, C.D. (1964) . - M.Sc. Thesis, University of Western Australia.

Heyward, F., and Barnette, R.M. (1934). - Effect of frequent fires on chemical composition of forest soils in the longleaf pine region. Tech. Bull. Fla. Agric. Exp. Sta. No.265. 
Horton, R.E. (1933). - The role of infiltration in the hydrologic cycle. Trans. Amer, Geophys. Un. 14: 446-60.

Horton, R.E. (1945) . - Erosional development of streams and their drainage basins : Hydrophysical approach to quantitative morphology. Bull. Geol. Soc. Amer. 므: 275-370.

Jamison, V.C. (1945) . - The pehetration of irrigation and rain water into sandy soils of Central Florida. Proc. Soil Sci. Soc, Amer. 10: 25-9.

Jamison, V.C. (1946). - Resistance to wetting in the surface of sandy soils under citrus trees in Central Florida and its effect upon penetration and the efficiency of irrigation. Proc. Soil Sci. Soc. Amer. 11: 103-9.

Kawaguchi, T., and Takiguchi, K. (1953) . - Experiments on the function of ground cover in erosion control (preliminary report). J. Japanese For, Soc. 35: 73-7.

Kittredge, J. (1948) . - "Forest Influences". (McGraw-Hill : New York).

Lamb, D. (1965) . - Turbidity investigations in the Cotter Catchment (preliminary report). Internal Report Forest Research Institute (typewritten). Lassen, L., Lull, H.W., and Frank, B. (1952) . - Some soilplant-water relations in watershed management. Circ. U.S. For. Serv. No.910.

Laws, J.0., and Parsons, D.A. (1943) . - The relation of raindrop size to intensity. Trans. Amer. Geophys. Un. , 24: 452-60. 
Leeper, G.W. (1957) . - "Introduction to Soil Science". (Melbourne Univ. Press).

Mannering, J.V., and Meyer, L.D. (1963). - The effects of various rates of surface mulch on infiltration and erosion. Proc. Soil Sci. Soc. Amer. 27: 84-6.

Marshall, T.S., and Stirk, G.B. (1950). - The effect of lateral movement of water in soil on infiltration measurements. Aust. J. Agric. Res, $\underline{\underline{1}}$ : 253-65.

Marston, R.B. (1952) - - Ground cover requirements for summer storm run-off control on aspen sites in Northern Utah. J.For, 50: 303-7.

Meginnes, H.G. (1935). - Effect of cover on surface run-off and erosion in the Loessial Uplands of Mississippi. U.S. Dep. Agric. Circ. 347.

Metz., L.J., Lotti, T., and Klawitter, R.A. (1961) . - Some effects of prescribed burning on coastal plain forest soil. Sta. Pap. S.E. For. Exp. Sta. No.133.

Meyer, L.D. (1958) . - An investigation of methods for simulating rainfall on standard run-off plots, etc. Spec. Rep. 81. A.R.S. U.S.D.A. and Purdue Univ., Agric. Exp. Sta. Musgrave, G.W. (1935) . - The infiltration capacity of soils in relation to the control of surface run-off and erosion. J. Amer. Soc. Agron. 27: 336-45.

Orr, H.K. (1957). - Effects of plowing and seeding on some forage production and hydrologic characteristics of a subalpine range in Central Utah. Res. Pap. Intermtn. For. Ra. Exp. Sta. No.47. 
Orr, H.K. (1960) . - Soil porosity and bulk density on grazed and protected Kentucky bluegrass range in the Black Hills. J. Range Mgmt. 13: 80-6.

0sborn, B. (1954). - Effectiveness of cover in reducing soil splash by raindrop impact. J. Soil Wat. Conserv. $\underline{\underline{9}}: 70-6$.

Packer, P.E. (1951). - An approach to watershed protection criteria. J, For. 年: 639-44.

Packer, P.E. (1953). - Effects of trampling disturbance on watershed condition, run-off and erosion, J,For. 피: 28-31.

Philip, J.R. (1957). - The theory of infiltration : 5. The influence of the initial moisture content. Soil Sci. 84: 329-46.

Post, F.H., and Dreibelbis, F.R. (1942) . - Some influences of frost penetration and microclimate on the water relationship of woodland, pasture, and cultivated soils. Proc. Soil Sci. Soc. Amer. 7: 97-104.

Pryor, L.D. (1955) . - Plant Communities. In "The Australian Capital Territory as a Region". (Halstead : Sydney). Rowe, P.B. (1948) . - Influence of woodland chaparral on soil and water in central California. Calif. Dept. Nat. Resources, Div. Forestry .

Sampson, A.W. (1944). - Effect of chaparral burning on soil erosion and soil moisture relations. Ecology 25: 171-91. 
Scott, V.H. (1956). - Relative infiltration rates of burned and unburned upland soils. Trans. Amer, Geophys. Un. 37: 67-9. Smith, D.D. (1964). - Rainfall simulation - for increased knowledge of run-off and erosion processes. Agric. Engn. St. Joseph Mich. 45: 618-9.

Smith, H.L., and Leopold, L.B. (1942) . - Infiltration studies in the Pecos River Watershed, New Mexico, and Texas. Soil Sci. $\underline{\underline{53}}$ : 195-204.

Smith, E.J., and Smith, B. (1950). - Rainfall rates and drop size distribution. C.S.I.R. Div. Radiophysics R.P.L. 56. Tackle, D. (1962) . - Infiltration in a Western Larch/Douglas Fir stand following cutting and slash treatment. Res. Note Intermtn. For. Ra. Exp. Sta. No.89.

Tisdall, A.L. (1951), - Antecedent soil moisture in its relation to infiltration. Aust. J.Agric. Res. 2: 342-8.

Van't Woudt, B.D. (1959). - Particle coatings affecting wettability of soils. J. Geophys. Res. 64: 263-7.

Veihmeyer, F.J., and Johnston, C.N. (1944). - Soil moisture records from burned and unburned plots in certain grazing areas of California. Trans. Amer. Geophys, Un. 25: 72-84.

Wilde, S.A., and Voigt, G.K. (1955) . - "Analysis of Soils and Plants for Foresters and Horticulturists". (Edwards : Ann Arbor).

Wilm, H.G. (1943). - The application and measurement of artificial rainfall on types $F A$ and $F$ infiltrometers. Trans, Amer. Geophys. Un. 24: 480-7. 
Wischmeier, W.H., and Smith, D.D. (1958) . - Rainfall energy and its relationship to soil loss. Trans. Amer. Geophys. Uni.. 으: 285-91.

Woodward, L. (1943) . - Infiltration - capacities of some plantsoil complexes on Utah range watershed lands.

Trans. Amer. Geophys. Un. . 24: 468-73. 


\section{APPENDIX I}

Detailed descriptions of study sites

\section{Site A}

The elevation was 2,100 feet, the aspect north-westerly and the slope about $16^{\circ}$.

The eucalypt forest was a low quality dry sclerophyll type and the dominant species were Eucalyptus macrorhyncha. E. rossii and E. polyanthemos. The dominant ground cover was sclerophyll litter which formed an incomplete cover, as the area was burnt in 1957 and a full ground cover had not developed. Shrubs occurred sporadically, the main ones being Daviesia mimosoides and Hardenbergia violaceae. Scattered clumps of grass were present, mainly Danthonia pallida, though Poa caespitosa occurred in sheltered areas. Other herbs were uncommon, but orchids (chiefly Diuris sulphurea) were apparent in spring.

The pine forest (Pinus radiata) was established in 1934 and dominated the site. Pine litter formed a continuous ground cover and in places was several inches thick. Scattered clumps of Danthonia pallida were common and coppice growth of E. polyanthemos still persisted.

The soil type was a well developed red podzolic derived from fine grained metamorphosed sediments. A complete profile description is shown in Figure 33.

\section{Site B}

The elevation was 2,200 feet, the aspect north-westerly and the slope about $15^{\circ}$.

The eucalypt forest was a dry sclerophyll type, the 
Litter rests abruptly on $\mathrm{Al}$.

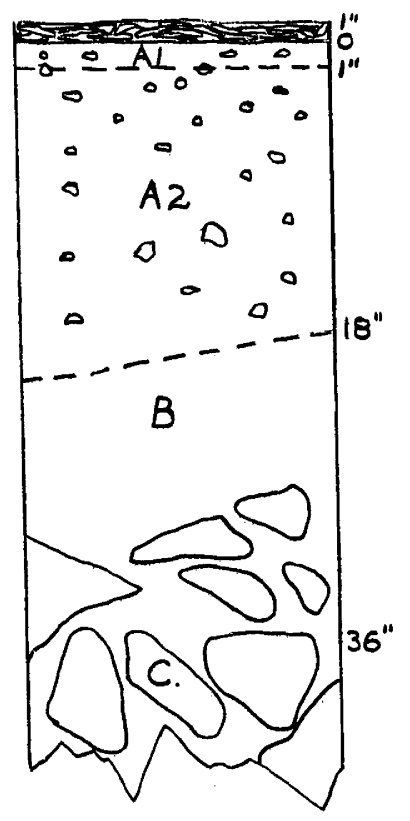
Al. Gray loamy sand, strongly leached. stones common.

A2. Light gray, almost white, loam, strongly leached, stones common.

B. Mottled yellowish-red clay, very compact, few stones.

C. Fine grained metamorphosed sediments.

FIGURE 33 Site A - Red podzolic.

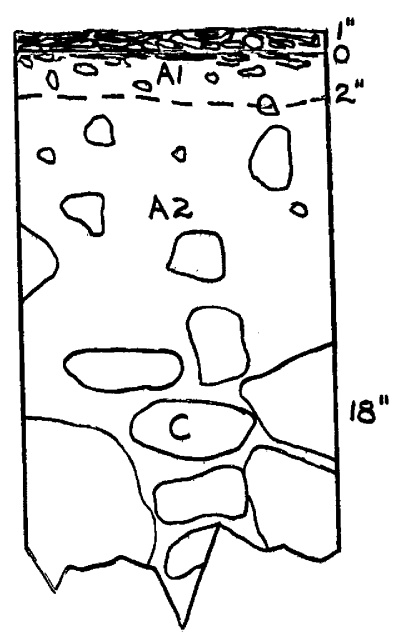

Litter merges with mineral soil.
Al. Gray loam to sandy loam, stones prevalent.
A2. Light gray to pale yellow clay loam, stones prevalent.
C. Deeply weathered and fragmented quartz porphry.

FIGURE 34 Site B - Skeletal minimal yellow podzolic. 
dominant species being E. macrorhyncha, E. bridgesiana, and E. dives. E. robertsoni, E. rossii and E. maculosa also occurred. A few scattered tall shrubs occurred, particularly in sheltered areas; mainly Bursaria spinosa and Indigofera australis. Grasses and low shrubs were the most obvious part of the lower stratum, the main grasses being Themeda australis and Danthonia pallida; and the main shrubs being Acacia buxifolia, Grevillea lanigera, Melichrus urceolatus, Hibbertia obtusifolia. Pimelia linifolia and Leucopogon attenuatus. Other herbs were uncommon. The soil was well covered with a layer of sclerophyll litter. The pine forest (Pinus radiata) was established in 1953 and dominated the site. The ground was well covered with pine litter, and because of the heavy shade almost all living vegetation had been eliminated from the ground stratum. Occasional clumps of Danthonia pallida and Poa caespitosa were found where shading was not so severe.

The soil type was a skeletal minimal yellow podzolic derived from quartz porphry. A detailed profile description is shown in Figure 34.

\section{Site C}

The elevation was 2,600 feet, the aspect south-westerly and the slope about $25^{\circ}$.

The eucalypt forest was a dry sclerophyll type, the dominant species being $E$. dives and E. macrorhyncha, with E. bridgesiana occurring as a subordinate species. The ground was well covered with sclerophyll litter and an almost continuous cover of Poa caespitosa. Shrubs and other herbs were uncommon. 
The pine forest (Pinus radiata) was established in 1957, but canopy closure had not occurred, so there was little needle fall. The ground was moderately covered with Poa caespitosa.

The soil type was a skeletal minimal yellow podzolic derived from acid tuff. A detailed profile description is shown in Figure 35.

\section{$\underline{\text { Site D }}$}

The elevation was 3,300 feet, the aspect northerly and the slope about $21^{\circ}$.

The eucalypt forest was a dry sclerophyll type and the dominant species was $\underline{E}$. dives, with $\underline{E}$. robertsoni and E. maculosa as subordinate species. Tall wattles (Acacia falciformis) were common and formed an intermediate stratum. The ground was well covered with sclerophyll litter and bracken fern (Pteridium esculentum). Shrubs were uncommon, but Daviesia ulicifolia occurred sporadically.

The pine forest (Pinus radiata) was established in 1960 and little needle fall had occurred. The ground was poorly covered with low shrubs, chief among them being Daviesia ulicifolia, Hibbertia obtusifolia and Tetratheca ericifolia. Pteridium esculentum occurred thickly in patches, and herbs such as Dianella tasmanica and Stylidium graminifolium occurred sporadically. Cassinia aculeata was common, particularly on severely disturbed areas.

The soil type was a skeletal minimal red podzolic derived from fine grained sandstones and mudstones. A detailed profile description is shown in Figure 36. 


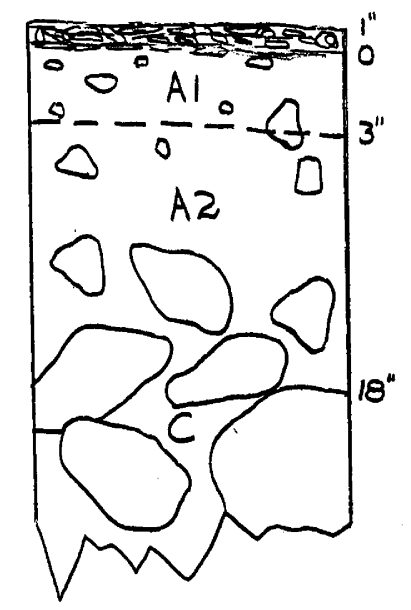

Litter merges with mineral soil.

Al. Dark gray loam, stones prevalent.

A2. Light gray to pale yellow loam to clay loam.

C. Deeply weathered and fragmented acid tuff.

FIGURE 35 Site C - Skeletal minimal yellow podzolic

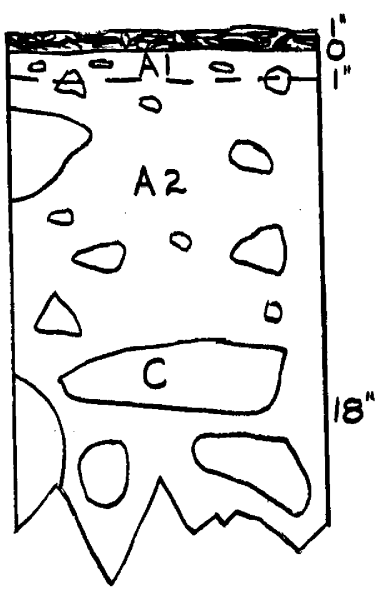

Litter rests abruptly on Al.
Al. Gray loam to silty loam, stones prevalent.

A2. Very pale brown to reddish-yellow silty clay loam to clay loam. stones prevalent.

C. Fragmented fine grained sediments.

FIGURE 36 Site D - Skeletal minimal red podzolic. 


\section{Site E}

The elevation was 2,450 feet, the aspect northerly and the slope about $12^{\circ}$.

The eucalypt forest was a low quality dry sclerophyll type and the dominant species was $\underline{E}$. dives, with E. maculosa as a subordinate species. The soil was well covered with sclerophyll litter. Shrubs were uncommon but Daviesia ulicifolia occurred sporadically. Danthonia pallida was common in patches but other herbs were uncommon.

The pine forest (Pinus radiata) was planted in 1955 and the forest floor was well covered with pine litter and clumps of Poa caespitosa.

The soil type was a skeletal minimal yellow pödzolic derived from fine grained sandstones and mudstones. A complete profile description is shown'in Figure 37.

\section{Site F}

Site $F$ was located on a firebreak between a 1934 Pinus radiata plantation and a low quality dry sclerophyll eucalypt forest. The elevation was 2,600 feet, the aspect south-easterly and the slope about $18^{\circ}$. The firebreak was almost bare of vegetation, but the forest floors on either side were well covered with leaf litter.

The soil type was a skeletal minimal yellow podzolic derived from fine grained metamorphosed sediments. A complete profile description is shown in Figure 38. 


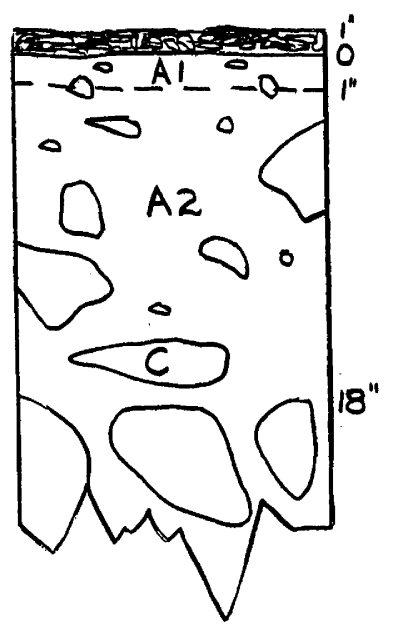

Litter rests abruptly on $\mathrm{Al}$.

Al. Gray silty loam, stones prevalent.

A2. Pale brown to yellow clay loam.

C. Fine grained sediments .

FIGURE 37 Site E - Skeletal minimal yellow podzolic

No litter layer.

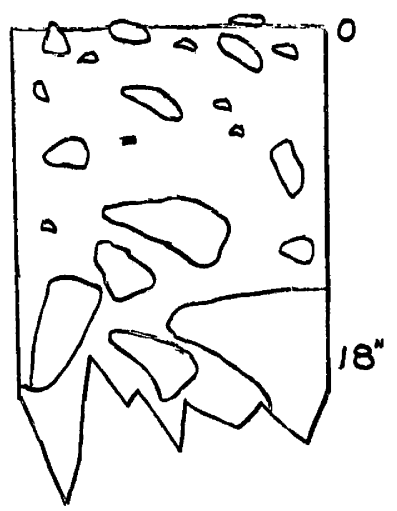

No Al horizon

A2. Light gray, almost white loamy sand, merging into a pale yellow loam.

C. Fine grained metamorphosed sediment.

FIGURE 38 Site F - Skeletal minimal yellow podzolic. 


\section{Site G}

Site $G$ was located in a 1941 pine plantation (Pinus

radiata) at Stromlo Forest about six miles west of Canberra. The elevation was 1,850 feet, the aspect north-westerly and the slope about $5^{\circ}$. The forest floor was well covered with leaf litter: and almost all other vegetation was excluded by dense shading from the canopy.

The soil type was a yellow podzolic derived from acid tuff. A complete profile description is shown in Figure 39. 


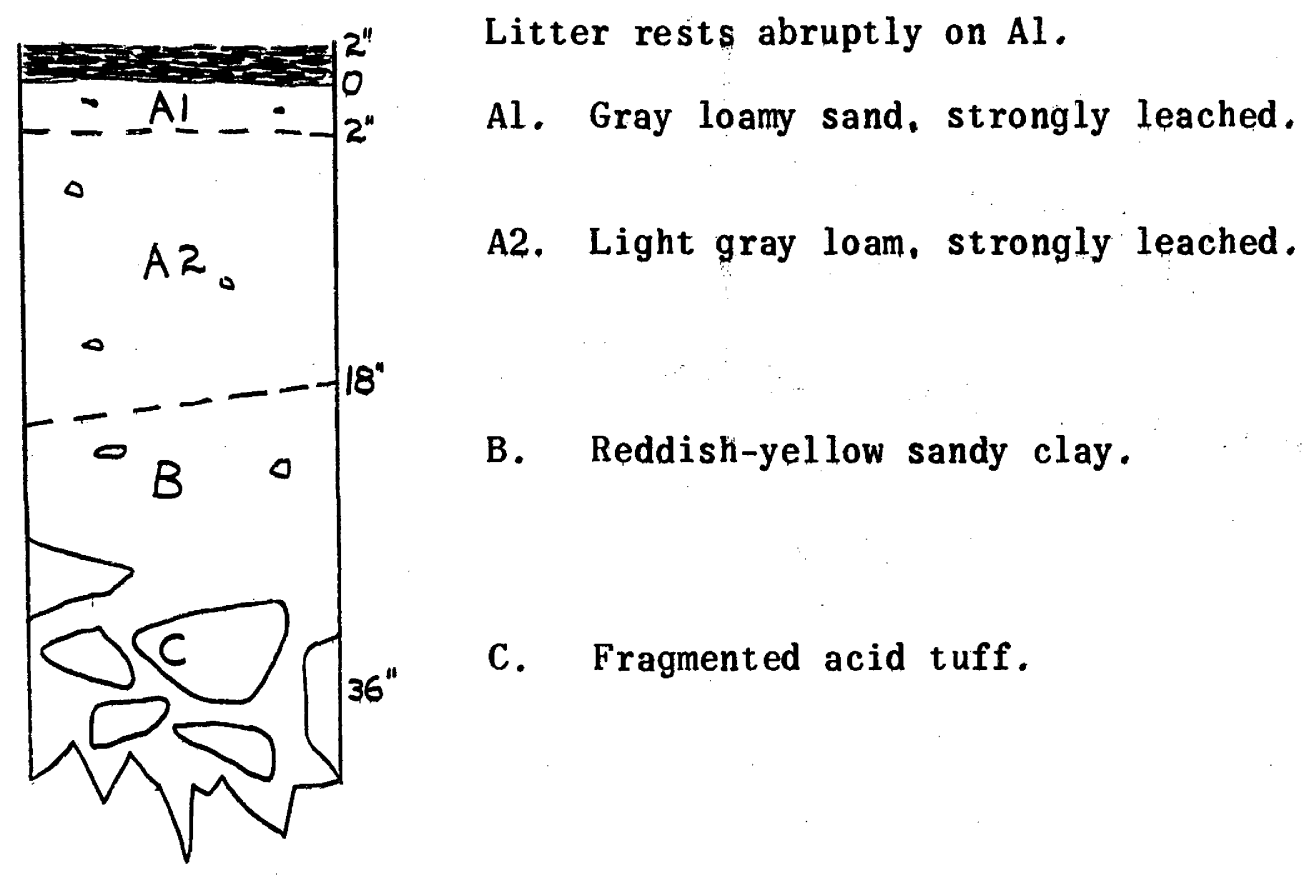

FIGURE 39 Site G - Yellow podzolic. 
APPENDIX II

Weather pattern during study period

TABLE 1 Monthly rainfall for each site during study period

\begin{tabular}{|l|c|c|c|c|}
\hline \multirow{2}{*}{ Month } & \multicolumn{4}{|c|}{ Rainfall in Points } \\
\cline { 2 - 5 } & $\begin{array}{c}\text { Site A } \\
(2,100 \mathrm{ft})\end{array}$ & $\begin{array}{c}\text { Site B } \\
(2,200 \mathrm{ft})\end{array}$ & $\begin{array}{c}\text { Site C } \\
(2,600 \mathrm{ft})\end{array}$ & $\begin{array}{c}\text { Site } \mathrm{D} \\
(3,300 \mathrm{ft})\end{array}$ \\
\hline October & 208 & 155 & 156 & 157 \\
November & 108 & 139 & 135 & 147 \\
December & 347 & 288 & 261 & 282 \\
1964 & & & & \\
January & 293 & 249 & 205 & 120 \\
February & 154 & 154 & 121 & 162 \\
March & 541 & 522 & 523 & 553 \\
April & 596 & 657 & 599 & 978 \\
May & 205 & 245 & 241 & 270 \\
June & 241 & 347 & 329 & 387 \\
July & 798 & 1148 & 1046 & 1227 \\
August & 229 & 307 & 267 & 380 \\
Sept ember & 519 & 625 & 590 & 637 \\
\hline \multirow{2}{*}{ Total } & 4239 & 4836 & 4473 & 5300 \\
\hline
\end{tabular}


APPENDIX II (Contd.)

TABLE 3 Mean monthly maximum temperature and minimum humidity at Uriarra and number of days between rainfalls greater than 10 points at site $A$.

\begin{tabular}{|c|c|c|c|}
\hline Month & $\begin{array}{l}\text { Mean maximum } \\
\text { temperature } \\
\left({ }^{0} F\right)\end{array}$ & $\begin{array}{l}\text { Mean minimum } \\
\text { humidity } \\
\text { (\%) }\end{array}$ & $\begin{array}{c}\text { Days between } \\
\text { falls }\end{array}$ \\
\hline 1963 & & & \\
\hline October & 68.5 & 44 & 28 \\
\hline November & 70.6 & 42 & 21 \\
\hline December & 77.5 & 40 & 22 \\
\hline 1964 & & & \\
\hline January & 79.7 & 27 & 15 \\
\hline February & 79.3 & 31 & 22 \\
\hline March & 75.5 & 36 & 24 \\
\hline April & 67.4 & 52 & 11 \\
\hline May & 56.8 & 59 & 23 \\
\hline June & 52.6 & 53 & 19 \\
\hline July & 48.1 & 62 & 8 \\
\hline August & 53.1 & 50 & 9 \\
\hline September & 58.5 & 48 & 11 \\
\hline
\end{tabular}




\section{APPENDIX II (Contd.)}

TABLE 2 Frequency of rainfall in excess of 40 points/hour (Maximum 10 minute intensity)

\begin{tabular}{|l|c|c|c|c|}
\hline \multirow{2}{*}{ Month } & \multicolumn{4}{|c|}{ Number of Falls } \\
\cline { 2 - 5 } & Site A & Site B & Site C & Site D \\
\hline October & 2 & 2 & 2 & 2 \\
November & 1 & 1 & 1 & 1 \\
December & 5 & 4 & 4 & 4 \\
\multicolumn{1}{|c|}{1964} & & & & \\
January & 3 & 3 & 3 & 1 \\
February & 1 & 1 & 1 & 2 \\
March & 1 & 1 & 1 & 1 \\
April & 1 & 2 & 2 & 2 \\
May & 1 & 1 & 1 & 1 \\
June & 1 & 1 & 1 & 1 \\
July & 0 & 0 & 0 & 0 \\
August & 0 & 0 & 0 & 0 \\
Sept ember & 0 & 0 & 0 & 0 \\
\hline \multicolumn{1}{|c|}{ Total } & 15 & 15 & 15 & 14 \\
\hline
\end{tabular}




\begin{tabular}{|c|c|c|c|}
\hline & \begin{tabular}{ll}
$\because$ & $n$ \\
\hdashline & 2 \\
0 & 0
\end{tabular} & ษั & 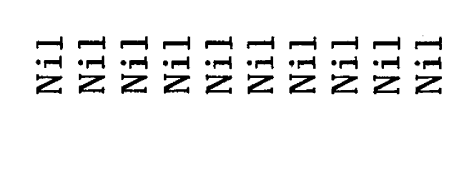 \\
\hline$\underset{\infty}{\stackrel{\infty}{\leftrightarrows}}$ & 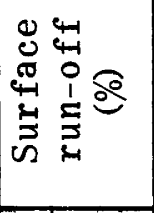 & $\begin{array}{l}\sim \\
\sim \\
\sim\end{array}$ & 舟 \\
\hline 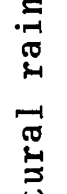 & 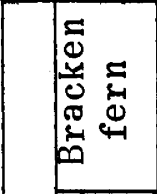 & 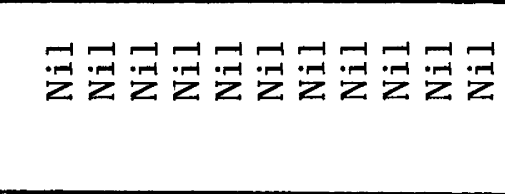 & 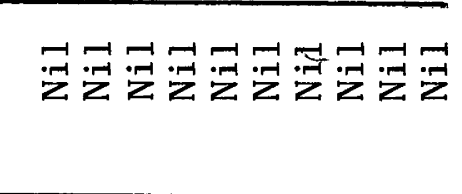 \\
\hline 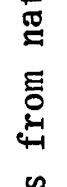 & $3^{\sqrt[n]{\sqrt[n]{2}}}$ & 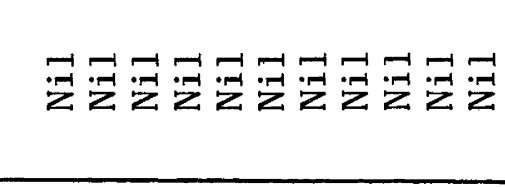 & 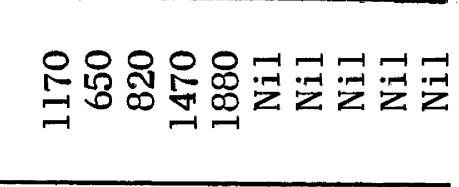 \\
\hline $\begin{array}{l}0 \\
2 \\
0 \\
-1 \\
=1 \\
0 \\
0\end{array}$ & 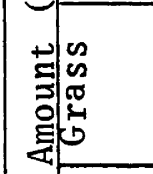 & 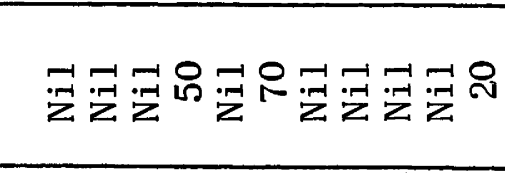 & 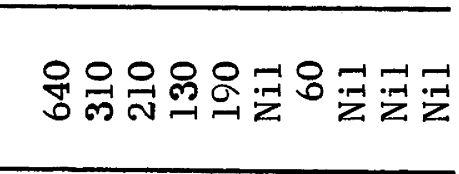 \\
\hline कृ & 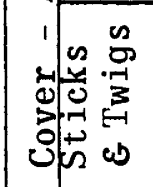 & 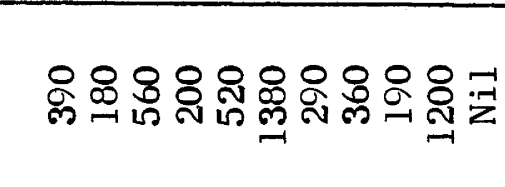 & 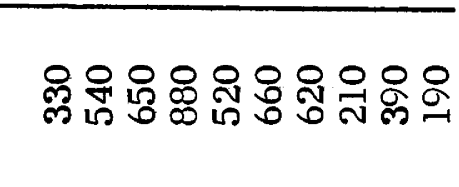 \\
\hline 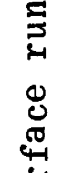 & 岱 & 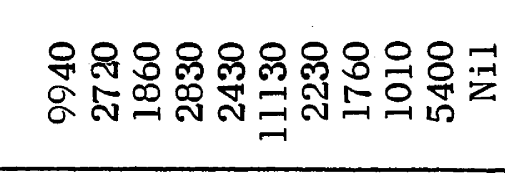 & 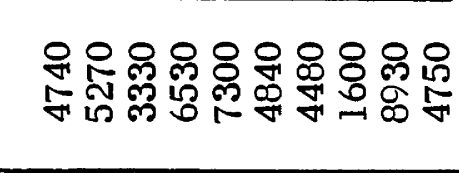 \\
\hline $\begin{array}{l}\vec{s} \\
\stackrel{+}{+} \\
=\end{array}$ & $\overbrace{0}^{0} \precsim$ & 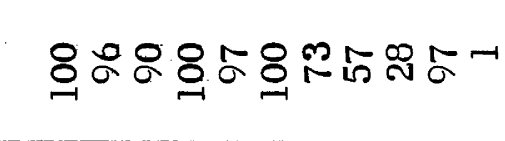 & 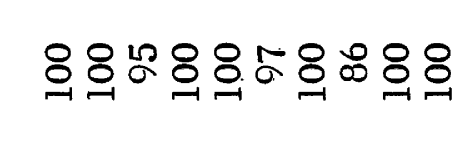 \\
\hline 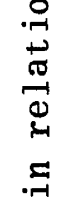 & 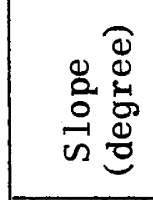 & 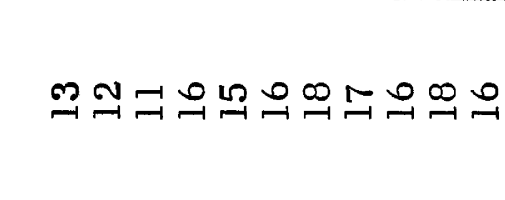 & 늡 \\
\hline 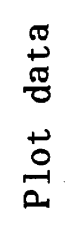 & $\underset{⿱ 亠 乂}{\stackrel{D}{\leftrightarrow}}$ & 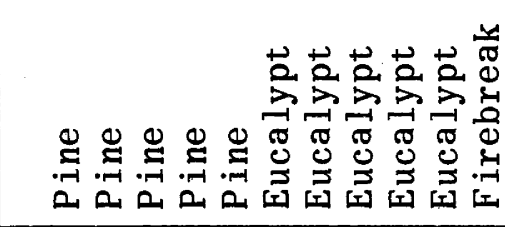 & 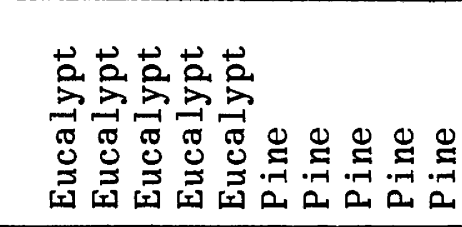 \\
\hline & $\underset{+}{\stackrel{+}{a}}$ & 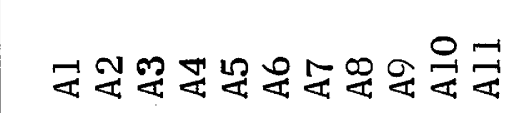 & 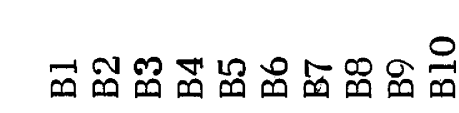 \\
\hline & 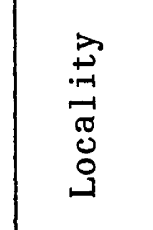 & 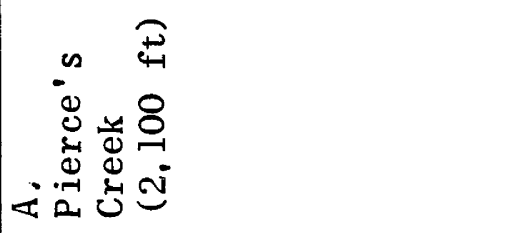 & 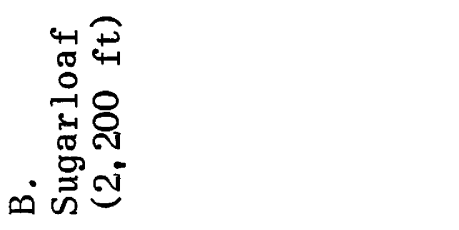 \\
\hline
\end{tabular}




\begin{tabular}{|c|c|c|}
\hline 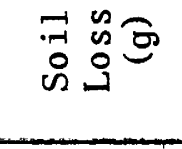 & 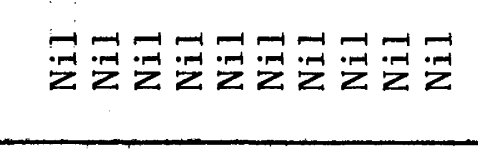 & 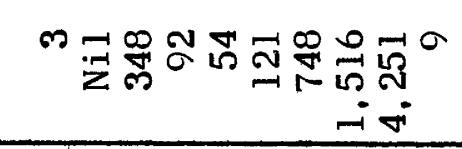 \\
\hline 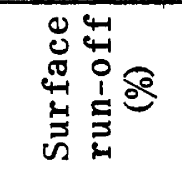 & 華 & 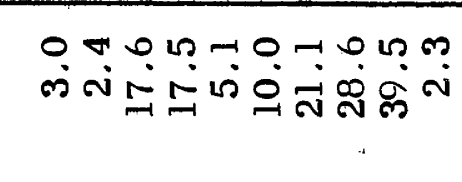 \\
\hline 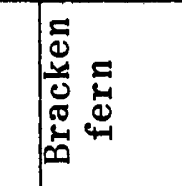 & 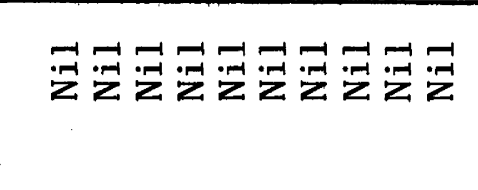 & 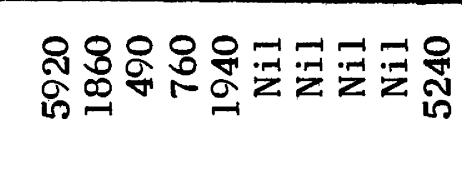 \\
\hline $8^{\frac{n}{\sqrt[n]{n}}}$ & 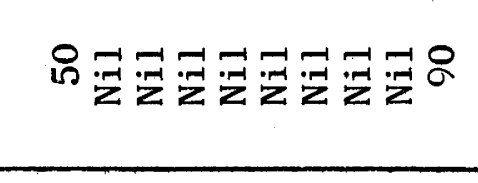 & 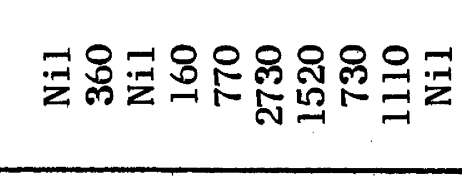 \\
\hline 题 & 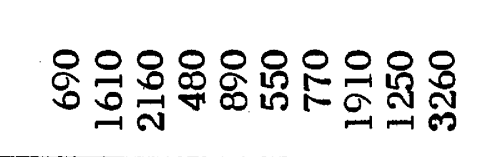 & 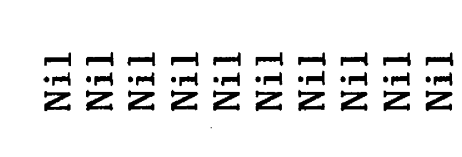 \\
\hline |con & 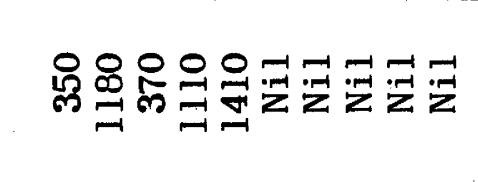 & 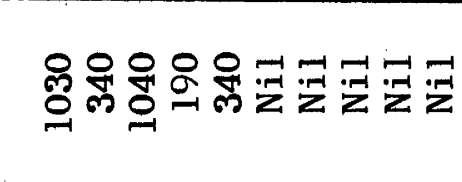 \\
\hline (1) & 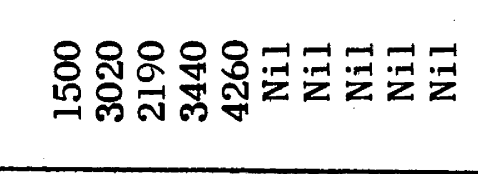 & 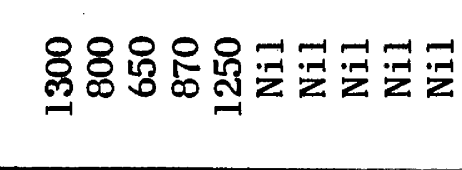 \\
\hline 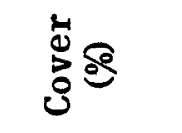 & 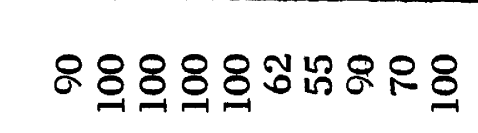 & 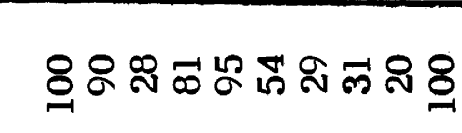 \\
\hline 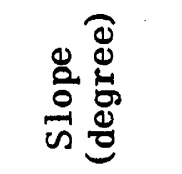 & సี న న & 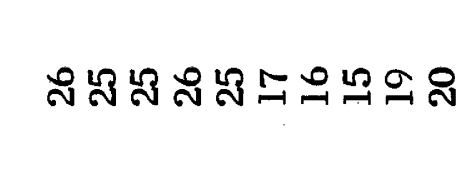 \\
\hline 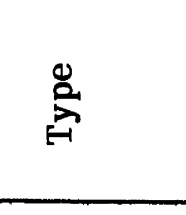 & 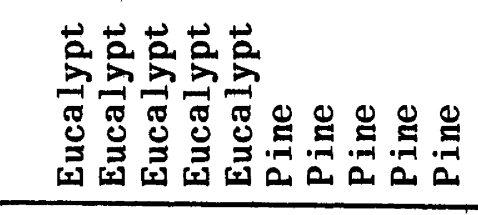 & 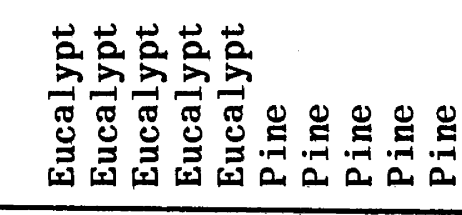 \\
\hline$\stackrel{\overrightarrow{0}}{a}$ & చ & 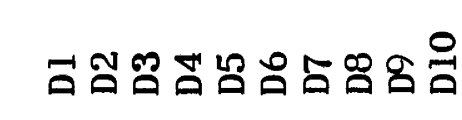 \\
\hline 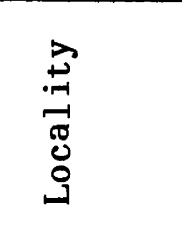 & 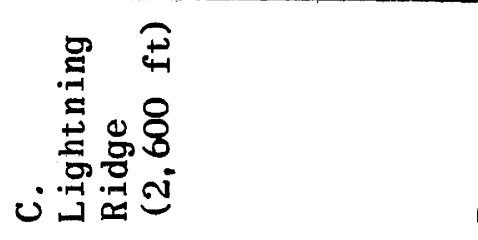 & 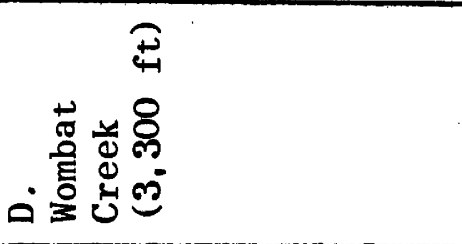 \\
\hline
\end{tabular}


So il physical characteristics

TABLE 1 Surface soil physical characteristics of permanent plots

\begin{tabular}{|c|c|c|c|c|c|c|}
\hline Plot & $\begin{array}{l}\text { Bulk } \\
\text { Density } \\
\text { (g/c.c.) }\end{array}$ & $\begin{array}{l}\text { Bulk } \\
\text { Density } \\
\text { (soil } \\
\text { alone) } \\
\text { (g/c.c.) }\end{array}$ & $\begin{array}{l}\text { Stone } \\
\text { Content } \\
(\%)\end{array}$ & $\begin{array}{l}\text { Total } \\
\text { Porosity } \\
\quad(\%)\end{array}$ & $\begin{array}{l}\text { Capillary } \\
\text { porosity } \\
(\%)\end{array}$ & $\begin{array}{l}\text { Non } \\
\text { Capillary } \\
\text { porosity } \\
(\%)\end{array}$ \\
\hline $\mathrm{Al}$ & 1.53 & 1.17 & 44 & 42 & 22 & 20 \\
\hline $\mathrm{A} 2$ & 1.42 & 0.90 & 55 & 46 & 17 & 29 \\
\hline A3 & 1.51 & 1.15 & 42 & 43 & 20 & 23 \\
\hline A4 & 1.33 & 0.79 & 58 & 50 & 19 & 31 \\
\hline A5 & 1.39 & 1.04 & 42 & 48 & 20 & 28 \\
\hline A6 & 1.22 & 0.95 & 35 & 54 & 23 & 31 \\
\hline A7 & 1.43 & 1.16 & 33 & 46 & 22 & 24 \\
\hline A8 & 1.51 & 0.91 & 61 & 43 & 22 & 21 \\
\hline A9 & 1.57 & 1.09 & 52 & 41 & 24 & 17 \\
\hline $\mathrm{A} 10$ & 1.62 & 1.13 & 54 & 39 & 24 & 15 \\
\hline All & 1.78 & 1.58 & 28 & 33 & 24 & 9 \\
\hline Bl & 1.42 & 0.95 & 52 & 46 & 24 & 22 \\
\hline B2 & 1.34 & 0.89 & 51 & 49 & 20 & 29 \\
\hline B3 & 1.30 & 0.83 & 53 & 51 & 20 & 31 \\
\hline B4 & 1.32 & 0.66 & 44 & 50 & 14 & 36 \\
\hline B5 & 1.40 & 0.99 & 46 & 47 & 23 & 24 \\
\hline B6 & 1.29 & 0.90 & 46 & 51 & 18 & 33 \\
\hline B7 & 1.40 & 1.24 & 26 & 47 & 26 & 21 \\
\hline B8 & 1.40 & 1.01 & 45 & 47 & 22 & 25 \\
\hline B9 & 1.44 & 1.14 & 37 & 46 & 23 & 23 \\
\hline $\mathrm{B} 10$ & 1.35 & 0.94 & 47 & 49 & 17 & 32 \\
\hline $\mathrm{Cl}$ & 1.26 & 0.89 & 47 & 52. & 23 & 29 \\
\hline $\mathrm{C} 2$ & 1.06 & 0.73 & 50 & 60 & 23 & 37 \\
\hline C3 & 1.11 & 0.63 & 57 & 58 & 21 & 37 \\
\hline $\mathrm{C} 4$ & 1.16 & 0.75 & 49 & $56^{\prime}$ & 21 & 35 \\
\hline C5 & 1.22 & 0.84 & 46 & 54 & 25 & 29 \\
\hline C6 & 1.20 & 0.71 & 56 & 55. & 22 & 33 \\
\hline $\mathrm{C} 7$ & 1.41 & 0.92 & 53 & 47 & 23 & 24 \\
\hline $\mathrm{C} 8$ & 1.30 & 0.91 & 47 & 51 & 24 & 27 \\
\hline $\mathrm{CO}$ & 1.25 & 0.81 & 51 & 53 & 19 & 34 \\
\hline $\mathrm{C} 10$ & 1.22 & 0.79 & 50 & 54 & 21 & 33 \\
\hline Dl & 0.96 & 0.77 & 28 & 64 & 31 & 33 \\
\hline D2 & 1.06 & 0.70 & 46 & 60 & 32 & 28 \\
\hline D3 & 1.10 & 0.86 & 30 & 58 & 33 & 25 \\
\hline D4 & 1.01 & 0.82 & 27 & 62 & 27 & 35 \\
\hline D5 & 1.00 & 0.80 & 29 & 62 & 32 & 30 \\
\hline D6 & 1.12 & 0.87 & 33 & 58 & 32 & 26 \\
\hline D7 & 1.17 & 0.94 & 30 & 56 & 31 & 25 \\
\hline D8 & 1.24 & 1.06 & 24 & 53 & 27 & 26 \\
\hline D9 & 1.40 & 1.26 & 19 & 47 & 33 & 14 \\
\hline Dl0 & 1.04 & 0.71 & 43 & 61 & 31 & 30 \\
\hline
\end{tabular}


APPENDIX IV (Contd.)

TABLE 2 - Subsoil physical characteristics of each site

\begin{tabular}{|c|c|c|c|c|c|c|c|c|}
\hline Site & Type & $\begin{array}{c}\text { Depth } \\
\text { (in.) }\end{array}$ & \begin{tabular}{|l} 
Bulk \\
density \\
(g/c.c.)
\end{tabular} & $\begin{array}{l}\text { Bulk } \\
\text { density } \\
\text { (soil } \\
\text { alone) } \\
(g / c . c .)\end{array}$ & $\begin{array}{l}\text { Stone } \\
\text { con- } \\
\text { tent } \\
(\%)\end{array}$ & $\begin{array}{l}\text { Total } \\
\text { porosity } \\
(\%)\end{array}$ & $\begin{array}{l}\text { Capillary } \\
\text { porosity } \\
(\%)\end{array}$ & \begin{tabular}{|l|} 
Non \\
Capil- \\
lary \\
poros \\
ity $(\%)$ \\
\end{tabular} \\
\hline A & $\begin{array}{l}\text { Pines } \\
\text { Pines } \\
\text { Eucs. } \\
\text { Eucs. }\end{array}$ & $\begin{array}{l}10-12 \\
18-20 \\
10-12 \\
18-20\end{array}$ & $\begin{array}{l}1.78 \\
1.55 \\
1.67 \\
1.41\end{array}$ & $\begin{array}{l}1.47 \\
1.55 \\
1.61 \\
1.41\end{array}$ & $\begin{array}{l}39 \\
\mathrm{Nil} \\
8 \\
\mathrm{Nil}\end{array}$ & $\begin{array}{l}33 \\
42 \\
37 \\
47\end{array}$ & $\begin{array}{l}23 \\
35 \\
27 \\
44\end{array}$ & $\begin{array}{r}10 \\
7 \\
10 \\
3\end{array}$ \\
\hline B & $\begin{array}{l}\text { Pines } \\
\text { Eucs. }\end{array}$ & $\begin{array}{l}10-12 \\
10 \div 12\end{array}$ & $\begin{array}{l}1.59 \\
1.59\end{array}$ & $\begin{array}{l}1.44 \\
1.44\end{array}$ & $\begin{array}{l}21 \\
21\end{array}$ & $\begin{array}{l}40 \\
40\end{array}$ & $\begin{array}{l}20 \\
17\end{array}$ & $\begin{array}{l}20 \\
29\end{array}$ \\
\hline C & $\begin{array}{l}\text { Pines } \\
\text { Eucs. }\end{array}$ & $\begin{array}{l}10-12 \\
10-12\end{array}$ & $\begin{array}{l}1.57 \\
1.57\end{array}$ & $\begin{array}{l}1.18 \\
1.18\end{array}$ & $\begin{array}{l}45 \\
45\end{array}$ & $\begin{array}{l}41 \\
41\end{array}$ & $\begin{array}{l}22 \\
19\end{array}$ & $\begin{array}{l}19 \\
22\end{array}$ \\
\hline D & $\begin{array}{l}\text { Pines } \\
\text { Eucs. }\end{array}$ & $\begin{array}{l}10-12 \\
10-12\end{array}$ & $\begin{array}{l}1.41 \\
1.41\end{array}$ & $\begin{array}{l}1.31 \\
1.31\end{array}$ & $\begin{array}{l}14 \\
14\end{array}$ & $\begin{array}{l}47 \\
47\end{array}$ & $\begin{array}{l}38 \\
33\end{array}$ & $\begin{array}{r}9 \\
14\end{array}$ \\
\hline
\end{tabular}


APPENDIX IV (Contd.)

TABLE 3 Soil particle size distribution of surface and subsoil at each site (International System)

\begin{tabular}{|c|c|c|c|c|c|c|}
\hline Site & Type & Horizon & $\begin{array}{l}\text { Depth } \\
\text { (in.) }\end{array}$ & $\%$ sand & $\%$ silt & $\%$ clay \\
\hline \multirow[t]{6}{*}{ A } & Pines & $\mathrm{Al}$ & $0-2$ & 74 & 15 & 11 \\
\hline & Pines & A2 & $10-12$ & 61 & 18 & 21 \\
\hline & Pines & B & $18-20$ & 34 & 16 & 50 \\
\hline & Eucalypts & $\mathrm{Al}$ & $0-2$ & 67 & 16 & 17 \\
\hline & Eucalypts & A2 & $10-12$ & 56 & 17 & 27 \\
\hline & Eucalypts & B & $18-20$ & 33 & 9 & 58 \\
\hline \multirow[t]{4}{*}{ B } & Pines & $\mathrm{Al}$ & $0-2$ & 62 & 13 & 25 \\
\hline & Pines & A2 & $10-12$ & 60 & 13 & 27 \\
\hline & Eucalypts & $\mathrm{Al}$ & $0-2$ & 72 & 12 & 16 \\
\hline & Eucalypts & A2 & $10-12$ & 58 & 16 & 26 \\
\hline \multirow[t]{4}{*}{$\mathrm{C}$} & Pines & $\mathrm{Al}$ & $0-2$ & 66 & 16 & 18 \\
\hline & Pines & A2 & $10-12$ & 63 & 16 & 21 \\
\hline & Eucalypts & $\mathrm{Al}$ & $0-2$ & 71 & 14 & 15 \\
\hline & Eucalypts & A2 & $10-12$ & 65 & 14 & 21 \\
\hline \multirow[t]{4}{*}{ D } & Pines & Al & $0-2$ & 51 & 28 & 21 \\
\hline & Pines & A2 & $10-12$ & 41 & 25 & 34 \\
\hline & Eucalypts & $\mathrm{Al}$ & $0-2$ & 55 & 25 & 20 \\
\hline & Eucalypts & A2 & $10-12$ & 45 & 25 & 30 \\
\hline
\end{tabular}




\section{APPENDIX V}

Nutrient losses during the study year

TABLE 1 Concentration of nutrients in the soil loss from each plot

\begin{tabular}{|l|c|c|c|}
\hline \multirow{2}{*}{ Plot } & \multicolumn{3}{|c|}{ Concentration of Nutrient } \\
\cline { 2 - 4 } & $\begin{array}{c}\text { Total nitrogen } \\
(\%)\end{array}$ & $\begin{array}{c}\text { Total potassium } \\
(\%)\end{array}$ & $\begin{array}{c}\text { Total phosphate } \\
\text { (p.p.m.) }\end{array}$ \\
\hline A1-A3 and & 0.577 & 2.74 & 2.440 \\
A7 & 0.480 & 2.53 & 1.392 \\
A8 & 0.432 & 1.74 & 1,100 \\
A9 & 0.330 & 1.84 & 1,140 \\
Al1 & 0.066 & 1.66 & 412 \\
D3 & 0.390 & 1.56 & 1.012 \\
D4 & Insufficient & 1.27 & 1,162 \\
D5 & sample & 1.48 & 1.456 \\
D6 & 0.524 & 1.40 & 1.000 \\
D7 & 0.420 & 1.66 & 940 \\
D8 & 0.422 & 1.18 & 668 \\
D9 & 0.314 & 2.10 & 460 \\
\hline & 0.140 & & \\
\hline
\end{tabular}


APPENDIX V (Contd.)

TABLE 2 Weight of nutrient losses from each plot during the study year

\begin{tabular}{|l|c|c|c|}
\hline \multirow{2}{*}{ Plot } & \multicolumn{3}{|c|}{ Weight of Nutrient (g/60 sq.ft.) } \\
\cline { 2 - 4 } & Total nitrogen & Total potassium & Total phosphate \\
\hline Al-A3 and A5 & 0.306 & 1.45 & 0.129 \\
A7 & 1.507 & 7.94 & 0.437 \\
A8 & 3.361 & 13.54 & 0.856 \\
A9 & 2.640 & 14.72 & 0.912 \\
Al1 & 7.073 & 177.89 & 4.415 \\
D3 & 1.357 & 5.43 & 0.352 \\
D4 & Insufficient & 1.17 & 0.107 \\
D5 & sample & & \\
D6 & 0.283 & 0.80 & 0.079 \\
D7 & 0.508 & 1.69 & 0.121 \\
D8 & 3.157 & 12.42 & 0.703 \\
D9 & 4.760 & 17.89 & 1.013 \\
\hline & 5.951 & 89.27 & 1.955 \\
\hline
\end{tabular}


Plot data in relation to infiltration studies

TABLE 1 Plot data in relation to infiltration studies on permanent plots

\begin{tabular}{|c|c|c|c|c|c|}
\hline \multirow[t]{2}{*}{ Plot } & \multirow[t]{2}{*}{$\begin{array}{l}\text { Weight ground } \\
\text { cover (g) }\end{array}$} & \multicolumn{2}{|c|}{$\begin{array}{l}\text { Constant infiltration } \\
\text { rate (pts/hr) }\end{array}$} & \multicolumn{2}{|c|}{$\begin{array}{l}\text { Soil loss } \\
(\mathrm{g})\end{array}$} \\
\hline & & Dry run & Wet run & Dry run & Wet run \\
\hline $\mathrm{Al}$ & 10,320 & 83 & 206 & 12 & $\mathrm{Nil}$ \\
\hline $\mathrm{A} 2$ & 2,900 & 73 & 104 & 13 & $\mathrm{Nil}$ \\
\hline A3 & 2.420 & 97 & 151 & 11 & $\mathrm{Nil}$ \\
\hline A4 & 3,080 & 181 & 276 & 7 & $\mathrm{Nil}$ \\
\hline A5 & 2,950 & 119 & 151 & 38 & $\mathrm{Nil}$ \\
\hline A6 & 12,580 & 231 & 273 & 15 & $\mathrm{Nil}$ \\
\hline $\mathrm{A} 7$ & 2,510 & 100 & 128 & 21 & 34 \\
\hline A8 & 2,120 & 113 & 140 & 38 & 31 \\
\hline A9 & 1,300 & 119 & 126 & 36 & 25 \\
\hline Al0 & 6,590 & 286 & $>320$ & 3 & $\mathrm{Nil}$ \\
\hline All & 20 & 58 & 44 & 687 & 2,528 \\
\hline $\mathrm{Bl}$ & 6,880 & 296 & 300 & $\mathrm{Nil}$ & $\mathrm{Nil}$ \\
\hline B2 & 6,770 & 253 & 259 & 3 & 3 \\
\hline B3 & 5,010 & 276 & 274 & $\mathrm{Nil}$ & 2 \\
\hline B4 & 9,010 & 286 & 301 & $\mathrm{Nil}$ & $\mathrm{Nil}$ \\
\hline В5 & 9.900 & 249 & 263 & 8 & 3 \\
\hline B6 & 5,510 & 222 & 220 & $\mathrm{NiI}$ & 4 \\
\hline B7 & 5,160 & 123 & 102 & 11 & $\mathrm{Nil}$ \\
\hline B8 & 1,800 & 109 & 79 & 10 & 11 \\
\hline B9 & 9,300 & 169 & 194 & 7 & 6 \\
\hline $\mathrm{B} 10$ & 4.940 & 174 & 198 & 7 & 6 \\
\hline $\mathrm{Cl}$ & 2,600 & & 211 & & 10 \\
\hline $\mathrm{C} 2$ & 5,800 & & 313 & & $\mathrm{Nil}$ \\
\hline C3 & 4.720 & & $>320$ & & $\mathrm{Nil}$ \\
\hline C4 & 5,020 & & 308 & & $\mathrm{Nil}$ \\
\hline C5 & 6,560 & & $>320$ & & $\mathrm{Nil}$ \\
\hline $\mathrm{C} 6$ & 550 & & $>320$ & & $\mathrm{Nil}$ \\
\hline C7 & 770 & & 293 & & 2 \\
\hline $\mathrm{C} 8$ & 1.910 & & 312 & & $\mathrm{Nil}$ \\
\hline $\mathrm{CO}$ & 1,250 & & 269 & & 2 \\
\hline $\mathrm{C} 10$ & 3,350 & & 320 & & $\mathrm{Nil}$ \\
\hline D1 & 8,240 & 219 & 240 & 5 & 4 \\
\hline $\mathrm{D} 2$ & 3,360 & 295 & 305 & $\mathrm{Nil}$ & $\mathrm{Nil}$ \\
\hline D3 & 2,170 & 82 & 83 & 53 & 28 \\
\hline D4 & 1.990 & 74 & 108 & 21 & $\mathrm{Nil}$ \\
\hline D5 & 4,300 & 136 & 156 & 19 & $\mathrm{Nil}$ \\
\hline D6 & 2,730 & 119 & 134 & 47 & 9 \\
\hline D7 & 1,520 & 79 & 109 & 86 & 48 \\
\hline D8 & 730 & 74 & 100 & 144 & 90 \\
\hline D9 & 600 & 77 & 75 & 503 & 281 \\
\hline D10 & 5,240 & 297 & 289 & $\mathrm{Nil}$ & $\mathrm{Nil}$ \\
\hline
\end{tabular}


APPENDIX VI (Contd.)

TABLE 2 Plot data in relation to infiltration studies on roving plots

\begin{tabular}{|c|c|c|c|c|c|c|c|c|}
\hline \multirow[t]{2}{*}{ Locality } & \multirow[t]{2}{*}{ Plot } & \multirow[t]{2}{*}{ Type } & \multirow{2}{*}{$\begin{array}{l}\text { Weight } \\
\text { ground } \\
\text { cover } \\
(g)\end{array}$} & \multicolumn{5}{|c|}{$\begin{array}{l}\text { Constant infiltration Soil loss } \\
\text { rate (pts/hr) }\end{array}$} \\
\hline & & & & $\begin{array}{l}\text { Dry } \\
\text { Run }\end{array}$ & $\begin{array}{l}\text { Wet } \\
\text { Run }\end{array}$ & $\begin{array}{l}\text { Bare } \\
\text { Run }\end{array}$ & $\begin{array}{l}\text { Dry } \\
\text { Run }\end{array}$ & $\begin{array}{l}\text { Wet } \\
\text { Run }\end{array}$ \\
\hline \multirow{17}{*}{$\begin{array}{l}\text { Site A } \\
\text { Pierce's } \\
\text { Creek } \\
(2,100 \mathrm{ft})\end{array}$} & & & & & & & & \\
\hline & Rl & Pine & 12,020 & 157 & 213 & 190 & 9 & 4 \\
\hline & R2 & Pine & 14.980 & 179 & 307 & 150 & 6 & $\mathrm{Nil}$ \\
\hline & R3 & $\begin{array}{l}\text { Fire- } \\
\text { break }\end{array}$ & 70 & 74 & 32 & 38 & 331 & 342 \\
\hline & $\mathrm{R} 4$ & $\begin{array}{l}\text { Fire- } \\
\text { break }\end{array}$ & 510 & 64 & 79 & 84 & 15 & 25 \\
\hline & R5 & $\begin{array}{l}\text { Fire- } \\
\text { break }\end{array}$ & 730 & 205 & $>320$ & 248 & 5 & $\mathrm{Nil}$ \\
\hline & R6 & Euc. & 3,060 & 136 & 176 & 151 & 69 & 30 \\
\hline & R7 & Euc. & 7,780 & 180 & $>320$ & 289 & 4 & $\mathrm{Nil}$ \\
\hline & R8 & Euc. & 13,500 & 295 & $>400$ & 294 & 1 & $\mathrm{Nil}$ \\
\hline & R9 & Euc. & 9.510 & $>320$ & $>320$ & 273 & $\mathrm{Nil}$ & $\mathrm{Nil}$ \\
\hline & $\mathrm{R} 10$ & Euc. & 1.220 & 193 & 196 & 199 & 20 & 15 \\
\hline & RIl & Euc. & 6,130 & 230 & 296 & 171 & 14 & $\mathrm{Nil}$ \\
\hline & $\mathrm{R} 12$ & Euc. & 2,880 & 136 & 145 & 123 & 67 & 38 \\
\hline & R13 & Euc. & 7,210 & 317 & $>320$ & 293 & $\mathrm{Nil}$ & $\mathrm{Nil}$ \\
\hline & $\mathrm{R} 14$ & Euc. & 7,220 & 278 & $>320$ & 228 & 7 & $\mathrm{Nil}$ \\
\hline & R 15 & Euc. & 4,330 & 199 & 257 & 213 & 21 & 17 \\
\hline & $\mathrm{R} 16$ & Euc. & 7.430 & 233 & $>320$ & 234 & 25 & $\mathrm{Nil}$ \\
\hline \multirow{9}{*}{$\begin{array}{c}\text { Site E } \\
\text { Shannon's } \\
\text { Block } \\
(2,450 \mathrm{ft})\end{array}$} & $\mathrm{R} 17$ & Euc. & 1,900 & 75 & 22 & & 85 & 33 \\
\hline & $\mathrm{R} 18$ & Euc. & 10,970 & 41 & 77 & & 28 & 12 \\
\hline & $\mathrm{R} 19$ & Euc. & 12,060 & 102 & 222 & & 29 & 6 \\
\hline & $\mathrm{R} 20$ & $\begin{array}{l}\text { Fire- } \\
\text { break }\end{array}$ & 530 & 32 & 15 & & 283 & 350 \\
\hline & $\mathrm{R} 21$ & $\begin{array}{l}\text { Fire- } \\
\text { break }\end{array}$ & 1.720 & 104 & 78 & & 51 & 57 \\
\hline & $\mathrm{R} 22$ & $\begin{array}{l}\text { Fire- } \\
\text { break }\end{array}$ & 4,150 & 231 & 272 & & $\mathrm{Nil}$ & $\mathrm{Nil}$ \\
\hline & $\mathrm{R} 23$ & Pine & 2,060 & 104 & 58 & & 60 & 43 \\
\hline & $\mathrm{R} 24$ & Pine & 2,970 & 91 & 40 & & 29 & 22 \\
\hline & $\mathrm{R} 25$ & Pine & 6.510 & 124 & 115 & & 11 & 6 \\
\hline \multirow{8}{*}{$\begin{array}{l}\text { Site F } \\
\text { Pierce s } \\
\text { Creek } \\
(2,600 \mathrm{ft})\end{array}$} & R34 & $\begin{array}{l}\text { Clover } \\
\text { trials }\end{array}$ & 140 & 50 & 36 & & 248 & 25.5 \\
\hline & R35 & " " & 530 & 172 & 166 & & 14 & 14 \\
\hline & R36 & $" \quad "$ & 840 & 108 & 97 & & 20 & 20 \\
\hline & R37 & " " & 430 & 160 & 179 & & 6 & 12 \\
\hline & R38 & $"$ " & 36 & 52 & 28 & & 589 & 487 \\
\hline & R39 & " " & 130 & 104 & 58 & & 49 & 53 \\
\hline & $\mathrm{R} 40$ & $" \quad "$ & 80 & 91 & 40 & & 86 & 108 \\
\hline & $\mathrm{R} 41$ & $"$ & 80 & 124 & 115 & & 34 & 27 \\
\hline
\end{tabular}




\section{Prescribed burning experiment}

Burning was carried out in compartment 60 of Stromlo Forest in a 1941 plantation of Pinus radiata. The trees had been pruned to eight feet and the forest floor was heavily covered with pine ltter. Slash piles were abundant. The burn was carried out during the afternoon of 10.11.64. Meteorological conditions*

Air temperature varied from 78 to $80^{\circ} \mathrm{F}$ and relative humidity from 29 to $31 \%$. The wind in the open (at Forest Research Institute headquarters) averaged 17 m.p.h. from 1400 to 1530 hours with occasional gusts to $31 \mathrm{~m} . \mathrm{p} . \mathrm{h}$. Wind in the forest averaged $3.4 \mathrm{~m} . \mathrm{p} . \mathrm{h}$. for the duration of the fire. Fuel and soil moisture contents ${ }^{*}$

Sticks and twigs averaged $15 \%$ moisture by weight. while the fine needle litter (tops) varied from 11.5 to $13.4 \%$. In contrast to this the duff layer had a moisture content of $93.5 \%$.

Soil moisture content was $20.8 \%$.

\section{Physical features of fire ${ }^{*}$}

The fire burnt fairly evenly up a $4^{0}$ slope with the flame height averaging 1.5 feet but reaching 9 feet in some of the slash piles. The mean forward rate of spread was 3.3 feet/minute and the mean rate of perimeter spread was 9.5 feet/minute.

* The information contained in these $\stackrel{\text { se }}{\text { *ctions was made }}$ available by Mr. N.P. Cheney of the Forest Research Institute. 
APPENDIX VII (Contd.)

Detailed infiltration data from prescribed burning experiment

\begin{tabular}{|c|c|c|c|c|c|c|c|}
\hline & \multirow{3}{*}{ Plot } & \multicolumn{3}{|c|}{ Pre Burn } & \multicolumn{3}{|c|}{ Post Burn } \\
\hline & & \multirow{2}{*}{$\begin{array}{l}\text { Wt. ground } \\
\text { cover - } \\
\text { Fine fuel } \\
\text { only* (g/ } \\
60 \mathrm{sq} . \mathrm{ft} .) \\
\end{array}$} & \multicolumn{2}{|c|}{$\begin{array}{l}\text { Constant } \\
\text { Infiltration } \\
\text { Rate (pts/hr) }\end{array}$} & \multirow{2}{*}{$\begin{array}{l}\text { Wt. ground } \\
\text { cover - } \\
\text { Fine fuel } \\
\text { only (g/ } \\
60 \text { sq.ft.) }\end{array}$} & \multicolumn{2}{|c|}{$\begin{array}{l}\text { Constant } \\
\text { Infiltration } \\
\text { Rate (pts/hr) }\end{array}$} \\
\hline & & & $\begin{array}{l}\text { Dry } \\
\text { run }\end{array}$ & $\begin{array}{l}\text { Wet } \\
\text { run }\end{array}$ & & $\begin{array}{l}\text { Dry } \\
\text { run }\end{array}$ & $\begin{array}{l}\text { Wet } \\
\text { run }\end{array}$ \\
\hline C & $\mathrm{R} 26$ & 6.750 & 231 & 190 & 6,750 & 226 & 161 \\
\hline $\mathrm{N}$ & $\mathrm{R} 27$ & 4,300 & 244 & 182 & 4,300 & 207 & 173 \\
\hline $\mathrm{R}$ & $\mathrm{R} 28$ & 4.850 & 223 & 161 & 4,850 & 211 & 179 \\
\hline L & $\mathrm{R} 29$ & 3,980 & 139 & 102 & 3,980 & 123 & 98 \\
\hline $\begin{array}{l}\mathrm{T} \\
\mathrm{R}\end{array}$ & R30 & 4,300 & 151 & 146 & 3,300 & 133 & 136 \\
\hline E & R31 & 4.850 & 256 & 233 & 3.910 & 202 & 179 \\
\hline $\begin{array}{l}\mathrm{T} \\
\mathrm{E}\end{array}$ & R32 & 6,750 & 320 & 228 & 5,090 & 256 & 230 \\
\hline D & R33 & 3,980 & 176 & 152 & 2,450 & 171 & 110 \\
\hline
\end{tabular}

* Pre burn weight of ground cover for the treated plots was estimated. 
Comparison between pines and eucalypts at each site

(Each value is the mean of five observations)

SITE A

\begin{tabular}{|c|c|c|c|c|c|}
\hline \multirow[b]{2}{*}{ Character } & \multicolumn{2}{|c|}{ Pines } & \multicolumn{2}{|c|}{ Eucalypts } & \multirow{2}{*}{$\begin{array}{l}\text { Significance } \\
\text { of difference } \\
\text { between means }\end{array}$} \\
\hline & Mean & $\begin{array}{l}\text { S.E. of } \\
\text { Mean }\end{array}$ & Mean & $\begin{array}{c}\text { S.E. of } \\
\text { Mean }\end{array}$ & \\
\hline $\begin{array}{l}\text { Surface run-off } \\
\text { for year }(\%)\end{array}$ & 13.3 & 3.2 & 9.7 & 2.9 & 0.50 \\
\hline $\begin{array}{l}\text { Soill loss for } \\
\text { year }(g / 60 \mathrm{sq} . \mathrm{ft})\end{array}$ & 44.4 & 12.1 & 386 & 173 & 0.10 \\
\hline Ground cover (\%) & 97 & 1.8 & 71 & 13.4 & 0.10 \\
\hline $\begin{array}{l}\text { Weight ground } \\
\text { cover }(g / 60 \text { sq.ft })\end{array}$ & 4330 & 1501 & 5020 & 2100 & 0.80 \\
\hline $\begin{array}{l}\text { Constant infil- } \\
\text { tration rate - } \\
\text { Dry run (pts/hr) }\end{array}$ & 111 & 19 & 170 & 37 & 0.20 \\
\hline $\begin{array}{l}\text { Constant infil- } \\
\text { tration rate - } \\
\text { Wet run (pts/hr) }\end{array}$ & 178 & 29 & 197 & 41 & 0.80 \\
\hline $\begin{array}{l}\text { Bulk density } \\
\text { (g/c.c.) }\end{array}$ & 1.44 & 0.04 & 1.47 & 0.07 & 0.70 \\
\hline $\begin{array}{l}\text { Bulk density } \\
\text { soil alone } \\
(\mathrm{g} / \mathrm{c} . \mathrm{c.})\end{array}$ & 1.01 & 0.07 & 1.05 & 0.05 & 0.70 \\
\hline $\begin{array}{l}\text { Total porosity } \\
(\%)\end{array}$ & 45.8 & 1.5 & 44.6 & 2.6 & 0.80 \\
\hline $\begin{array}{l}\text { Capillary } \\
\text { porosity }(\%)\end{array}$ & 19.6 & 0.8 & 23 & 0.4 & 0.01 \\
\hline $\begin{array}{l}\text { Non-capil lary } \\
\text { porosity }(\%)\end{array}$ & 26.2 & 2.0 & 21.6 & 2.8 & 0.30 \\
\hline $\begin{array}{l}\text { Stone content } \\
(\%)\end{array}$ & 48 & 3 & 47 & 6 & 0.90 \\
\hline
\end{tabular}


APPENDIX VIII (Contd.)

SITE B

\begin{tabular}{|c|c|c|c|c|c|}
\hline \multirow[b]{2}{*}{ Character } & \multicolumn{2}{|c|}{ Pines } & \multicolumn{2}{|c|}{ Eucalypts } & \multirow{2}{*}{$\begin{array}{l}\text { Significance } \\
\text { of difference } \\
\text { between means }\end{array}$} \\
\hline & Mean & $\begin{array}{l}\text { S.E. of } \\
\text { Mean }\end{array}$ & Mean & $\begin{array}{c}\text { S.E. of } \\
\text { Mean }\end{array}$ & \\
\hline $\begin{array}{l}\text { Surface run-off } \\
\text { for year (\%) }\end{array}$ & 4.3 & 1.0 & 2.3 & 0.3 & 0.10 \\
\hline $\begin{array}{l}\text { Soil loss for } \\
\text { year }(g / 60 \text { sq. } f t)\end{array}$ & 0 & & 0 & & \\
\hline $\begin{array}{c}\text { Ground cover } \\
(\%)\end{array}$ & 97 & 3 & 99 & 1 & 0.50 \\
\hline $\begin{array}{l}\text { Weight ground } \\
\text { cover (g/60 sq.ft) }\end{array}$ & 5344 & 1194 & 7874 & 879 & 0.20 \\
\hline $\begin{array}{l}\text { Constant in- } \\
\text { filtration rate- } \\
\text { Dry run (pts/hr) }\end{array}$ & 155 & 22 & 272 & 9 & 0.01 \\
\hline $\begin{array}{l}\text { Constant infil- } \\
\text { tration rate - } \\
\text { Wet run (pts/hr) }\end{array}$ & 163 & 27 & 279 & 9 & 0.01 \\
\hline $\begin{array}{l}\text { Bulk density } \\
\text { (g/c.c.) }\end{array}$ & 1.38 & 0.03 & 1.36 & 0.02 & 0.60 \\
\hline $\begin{array}{l}\text { Bulk density } \\
\text { soil alone } \\
\text { (g/c.c.) }\end{array}$ & 1.05 & 0.06 & 0.86 & 0.06 & 0.10 \\
\hline $\begin{array}{l}\text { Total porosity } \\
(\%)\end{array}$ & 48 & 0.9 & 48.6 & 0.9 & 0.70 \\
\hline $\begin{array}{l}\text { Capillary } \\
\text { porosity (\%) }\end{array}$ & 21.2 & 1.7 & 20.2 & 1.7 & 0.70 \\
\hline $\begin{array}{l}\text { Non-capillary } \\
\text { porosity }(\%)\end{array}$ & 26.8 & 2.4 & 28.4 & 2.5 & 0.70 \\
\hline $\begin{array}{l}\text { Stone content } \\
(\%)\end{array}$ & 40 & 4 & 49 & 2 & 0.10 \\
\hline
\end{tabular}


SITE C

\begin{tabular}{|c|c|c|c|c|c|}
\hline \multirow[b]{2}{*}{ Character } & \multicolumn{2}{|l|}{ Pines } & \multicolumn{2}{|c|}{ Eucalypts } & \multirow{2}{*}{$\begin{array}{l}\text { Significance } \\
\text { of difference } \\
\text { between means }\end{array}$} \\
\hline & Mean & \begin{tabular}{|c} 
S.E. of \\
Mean
\end{tabular} & Mean & $\begin{array}{l}\text { S.E. of } \\
\text { Mean }\end{array}$ & \\
\hline $\begin{array}{l}\text { Surface run-off } \\
\text { for year }(\%)\end{array}$ & 2.5 & 0.6 & 2.1 & 0.5 & 0.60 \\
\hline $\begin{array}{ll}\text { Soil loss for } \\
\text { year }(g / 60 \text { sq. } f t)\end{array}$ & 0 & & 0 & & \\
\hline Ground cover $(\%)$ & 75 & 8 & 98 & 2 & 0.05 \\
\hline $\begin{array}{l}\text { Weight ground } \\
\text { cover (g/60 sq.ft) }\end{array}$ & 1566 & 503 & 4940 & 667 & 0.01 \\
\hline $\begin{array}{l}\text { Constant infil- } \\
\text { tration rate - } \\
\text { Wet run (pts/hr) }\end{array}$ & 303 & 10 & 294 & 21 & 0.80 \\
\hline $\begin{array}{l}\text { Bulk density } \\
(\mathrm{g} / \mathrm{c} . \mathrm{c} .)\end{array}$ & 1.28 & 0.04 & 1.16 & 0.04 & 0.10 \\
\hline $\begin{array}{l}\text { Bulk density } \\
\text { soil alone } \\
\text { (g/c.c.) }\end{array}$ & 0.83 & 0.04 & 0.77 & 0.05 & 0.40 \\
\hline $\begin{array}{c}\text { Total porosity } \\
(\%)\end{array}$ & 52.0 & 1.4 & 56.0 & 1.4 & 0.10 \\
\hline $\begin{array}{l}\text { Capillary } \\
\text { porosity }(\%)\end{array}$ & 21.8 & 0.9 & 22.6 & 0.7 & 0.60 \\
\hline $\begin{array}{l}\text { Non-capillary } \\
\text { porosity }(\%)\end{array}$ & 30.2 & 2.0 & 33.4 & 1.8 & 0.30 \\
\hline$\underset{(\%)}{\text { Stone content }}$ & 51 & 2 & 50 & 2 & 0.60 \\
\hline
\end{tabular}


SITE D

\begin{tabular}{|c|c|c|c|c|c|}
\hline \multirow[b]{2}{*}{ Character } & \multicolumn{2}{|l|}{ Pines } & \multicolumn{2}{|c|}{ Eucapyts } & \multirow{2}{*}{$\begin{array}{l}\text { Significance } \\
\text { of difference } \\
\text { between means }\end{array}$} \\
\hline & Mean & $\begin{array}{l}\text { S.E. of } \\
\text { Mean }\end{array}$ & Mean & $\begin{array}{l}\text { S.E. of } \\
\text { Mean }\end{array}$ & \\
\hline $\begin{array}{l}\text { Surface run-off } \\
\text { for year }(\%)\end{array}$ & 20.3 & 6.6 & 9.1 & 3.5 & 0.20 \\
\hline $\begin{array}{ll}\text { Soil loss for } \\
\text { year }(g / 60 \text { sq. } f t)\end{array}$ & 1328 & 778 & 99 & 64 & 0.20 \\
\hline Ground cover (\%) & 47 & 14 & 79 & 13 & 0.20 \\
\hline $\begin{array}{l}\text { Weight ground } \\
\text { cover }(g / 60 \mathrm{sq} . \mathrm{ft}\end{array}$ & 2164 & 857 & 4012 & 1137 & 0.30 \\
\hline $\begin{array}{l}\text { Constant infil- } \\
\text { tration rate - } \\
\text { Dry run (pts/hr) }\end{array}$ & 129 & 43 & 161 & 42 & 0.70 \\
\hline $\begin{array}{l}\text { Constant infil- } \\
\text { tration rate - } \\
\text { Wet run (pts/hr) }\end{array}$ & 141 & 38 & 178 & 41 & 0.60 \\
\hline $\begin{array}{l}\text { Bulk density } \\
(g / c . c .)\end{array}$ & 1.19 & 0.06 & 1.03 & 0.02 & 0.05 \\
\hline $\begin{array}{l}\text { Bulk density } \\
\text { soil alone } \\
\text { (g/c.c.) }\end{array}$ & 0.97 & 0.09 & 0.79 & 0.03 & 0.20 \\
\hline $\begin{array}{l}\text { Total porosity } \\
(\%)\end{array}$ & 55.0 & 2.4 & 61.2 & 1.0 & 0.05 \\
\hline $\begin{array}{l}\text { Capillary } \\
\text { porosity (\%) }\end{array}$ & 30.8 & 1.0 & 31.0 & 1.0 & 0.90 \\
\hline $\begin{array}{l}\text { Non-capillary } \\
\text { porosity }(\%)\end{array}$ & 24.2 & 2.7 & 30.2 & 1.8 & 0.10 \\
\hline $\begin{array}{c}\text { Stone content } \\
(\%)\end{array}$ & 30 & 4 & 32 & 4 & 0.70 \\
\hline
\end{tabular}

